\title{
AIR QUALITY \\ INVESTIGATION IN \\ THE NIH RADIATION \\ ONCOLOGY BRANCH
}

\section{Andrew Persily \\ W. Stuart Dols \\ Steven J. Nabinger \\ David A. VanBronkhorst}

\author{
U.S. DEPARTMENT OF COMMERCE \\ Natlonal Instltute of Standards \\ and Technology \\ Natlonal Englneering Laboratory \\ Center for Bullding Technology \\ Bullding Environment Divislon \\ Galthersburg, MD 20899
}





\section{AIR QUALITY INVESTIGATION IN THE NIH RADIATION ONCOLOGY BRANCH}

\section{Andrew Persily W. Stuart Dols Steven J. Nabinger David A. VanBronkhorst}

U.S. DEPARTMENT OF COMMERCE Natlonal Institute of Standards and Technology Natlonal Englneering Laboratory Center for Bullding Technology Bullding Environment Divislon Galthersburg, MD 20899

Sponsored by:

Division of Englneering Servlces Natlonal Instltutes of Health Bethesda, Maryland

August 1989

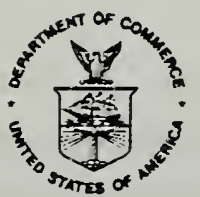

U.S. DEPARTMENT OF COMMERCE Robert A. Mosbacher, Secretary NATIONAL INSTITUTE OF STANDARDS AND TECHNOLOGY

Raymond G. Kammer, Acting Director 


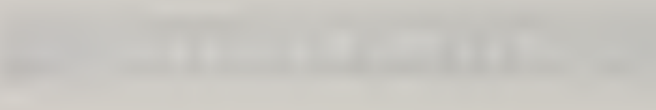

(4)

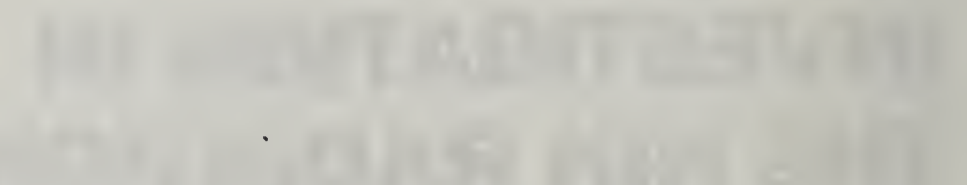

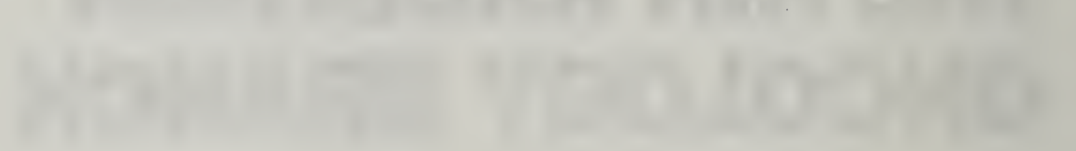

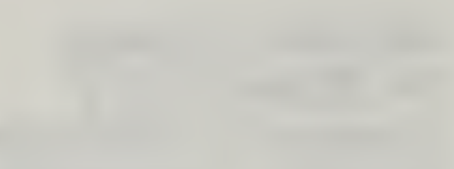




\section{ABSTRACT}

The Radiation Oncology Branch $(R O B)$ is located in the Clinical Center of the National Institutes of Health (NIH). The occupants of the ROB facility have expressed dissatisfaction with the air quality within the facility for several years. While a variety of occupant complaints have been noted, the specific causes have never been determined due to the complex nature of the facility and current limitations in the ability to diagnose indoor air quality problems. In order to identify the sources of the air quality problems in the ROB facility and to obtain recommendations for their solution, the Division of Engineering Services (DES) of $\mathrm{NIH}$ contracted with the Center for Building Technology at the National Institute of Standards and Technology (NIST, formerly the National Bureau of Standards) to conduct an indoor air quality investigation of the ROB facility.

The NIST study of the ROB facility involved five separate tasks. The first task was to review current design documents of the ROB HVAC systems and compare the design to the ASHRAE air quality standard and HHS construction guidelines. The second task was to conduct an inspection of the existing HVAC systems. The third task was to conduct tracer gas studies of the facility in order to quantify its air exchange and air movement characteristics. The fourth task was to monitor contaminant levels in the facility in order to determine if they exceed current standards. The fifth task was to recommend modifications to the facility in order to improve its indoor air quality. This report presents the results of all five tasks of the indoor air quality investigation of the Radiation Oncology Branch.

The first two tasks revealed several deficiencies in the design and current condition of the ROB ventilation system, such as significant differences between the design airflow rates and those recommended in current standards and guidelines. The airflow measurements in Task 3 showed many instances in which measured airflow rates were different from their design values. This task also revealed the existence of airflows within the building leading to the potential for pollutant transport within the building. The contaminant measurements conducted in Task 4 generally well below the maximum values in the ASHRAE air quality standard. Thermal comfort measurements revealed instances when the temperature and relative humidity were outside of ASHRAE comfort limits. Recommendations are made to remedy the deficiencies noted and to control the conditions contributing to the building's air quality problems.

Key words: air flow, air movement, building diagnostics; building performance; indoor air quality; indoor pollution; laboratory ventilation; tracer gas; ventilation. 


\section{EXECUTIVE SUMMARY}

The Radiation Oncology Branch (ROB) is part of the Clinical Center at the National Institutes of Health, located in Bethesda, Maryland outside of Washington, DC. The occupants of the facility have expressed dissatisfaction with the indoor air quality for several years, and the NIST investigation was intended to address this situation. The ROB is a multi-use facility, as is the rest of the Clinical Center, including offices, laboratories and patient treatment areas. The ROB facility is contained within the eight story B corridor of the Clinical Center (Building 10) and consists of two main sections, the Treatment Area and the support section. The Treatment Area, which is located underground, is used for patient reception and examination, radiation therapy, office and computer work, and various supporting activities such as film processing. The support section, which has two underground levels and one above ground, include offices, laboratories, and other work areas.

The indoor air quality complaints in the ROB are of several types, including a range of thermal comfort complaints that vary with time and location. Complaints also exist regarding stuffiness, air distribution, and odors. There have also been many complaints of typical "sick building syndrome" symptoms such as eye and respiratory irritation, often described by the occupants as "allergic" reactions. Most of the complaints are reported to have started after the B3B and B2.5B levels were renovated in March of 1987.

This summary describes the five tasks of the NIST investigation of the ROB and summarizes the findings of each. The five tasks included: (1) a review of the HVAC system design, (2) an inspection of the HVAC system, (3) a study of air exchange in the facility using tracer gas and other techniques, (4) the measurement of contaminant levels in the facility, and (5) the recommendation of modifications to the facility to alleviate the air quality problems.

\section{Task 1: Design Review of Ventilation System}

The first task of the ROB study was to review the current design documents of the HVAC systems, conduct a detailed engineering review of the ventilation system design, and compare the design to current ventilation standards and design guidelines. As this task began, it became apparent that a complete and up-to-date description of the ROB ventilation systems did not exist, and therefore such a description had to be developed. This involved locating and collecting current floor plans and mechanical drawings, fan schedules, and other relevant documentation. This information was carefully examined for completeness and consistency to develop a description of the ventilation systems serving the ROB.

In considering the ROB ventilation system design, it is important to keep in 
mind that this facility is only a portion of the larger B Corridor which itself is only a portion of Building 10. Airflows between the ROB and other areas in the building may be expected to impact the air quality within the ROB. The NIH/NIST agreement involves only the $\mathrm{ROB}$ facility, but its relation to the rest of the building must be considered. Very little current information on the $B$ Corridor ventilation system exists, but given the potential importance of interzone airflows to and from the $R O B$ this additional information needs to be documented in order to evaluate the $R O B$ ventilation system in the context of the whole building.

Although not all of the system design information was available for the Task 1 effort, a thorough analysis of the available information was conducted and several aspects of the design were identified that require attention as summarized below. While these items should be corrected, their impact on the air quality within the building cannot be stated without additional physical measurements of the conditions within the space.

The Treatment Area is only slightly oversupplied according to the ventilation system design. According to the 1983/84 HHS Guidelines, this patient treatment area should be pressurized relative to adjacent areas in the building, and the amount of oversupply in the design may not be sufficient to accomplish this.

There is no outdoor air supply for the reception area in the Treatment Area.

The modification of the supply fan serving Levels B3B and B2.5B may have resulted in these spaces being pressurized. The laboratory space on these levels should be depressurized relative to adjacent areas, and the exhaust airflow rates may need to be modified to achieve this. New design values of the supply diffuser airflow rates are needed since the existing values are based on the original supply fan airflow rate.

The ventilation design airflow rates for several individual rooms are not in accordance with the levels of ventilation recommended by ASHRAE Standard 62 and the HHS Guidelines. There are rooms which should have exhaust-dominated ventilation, but instead they have oversupplied or balanced ventilation. Other rooms have insufficient design air exchange rates according to the HHS Guidelines. There are also problems in the two copyrooms; one has no mechanical ventilation at all and one is connected to the return air system instead of the exhaust system.

There is a need for updated versions of the mechanical drawings and design airflow rates for the $R O B$ ventilation system that reflect the changes that have occurred in these spaces. Current information is also needed on the ventilation system design for the entire B Corridor. 


\section{Task 2: Inspection of the Ventilation System}

The purpose of Task 2 was to inspect the ROB ventilation systems in order to compare their installation to design and to determine if certain events have occurred that might lead to a system that does not function as intended. This effort involved an inspection of the occupied space and the suspended ceiling plenum space throughout the $R O B$ in order to compare the location and type of air diffuser and register in each room with the information contained in the mechanical drawings, to compare the ductwork layout with that shown in these same drawings, to evaluate the condition of the ductwork contained in the plenum space, and to look for water leaks or damage due to previous leaks. This inspection was conducted during the first two weeks of October 1988, and some of the deficiencies identified in this inspection have since been corrected.

The inspection of the ROB ventilation system identified several deficiencies in the current condition of the system. While some of these items definitely require attention and repair, it can not be stated how they may be affecting the air quality within the occupied space without making physical measurements of airflow rates and contaminant levels. The major items are summarized below:

There are several discrepancies between the ventilation system design and installation such as the existence of registers and ductwork that are not in the mechanical drawings, for example the area around Linac \#4. There are no design values for the airflow rates for these registers for use in testing their performance. The ventilation system design documentation should be updated in order to reflect these additional installations.

Many ceiling tiles are damaged from past and current water leaks. The water leaks should be repaired and the damaged tiles, as well as missing tiles, should be replaced.

The fan coil units in the ceiling plenums over Linacs \#1 through \#3 are pulling air from the plenum space and supplying this air to the occupied space. These units should be recirculating air from the occupied space, and this situation should be corrected.

Several smoke/fire control and inlet dampers in the Treatment Area were closed during the inspection, cutting off ventilation airflows to many rooms. These dampers were reopened, but their controls should be examined in order to prevent future damper closings. A system should be developed so that future closings are quickly identified and corrected.

There are several supply air diffusers, and one exhaust air grille, that have been blocked by the occupants because of uncomfortable air speeds and noise, due to excessive airflow rates. These diffusers and grilles should be adjusted so that 
these spaces can be provided their design airflows.

There are several openings in the exhaust duct serving Level $1 \mathrm{~B}$, including an old exhaust grille located above the suspended ceiling. These defects are leading to significant airflows from the plenum space into the exhaust air system, thereby decreasing the exhaust airflow rates into the individual rooms on this level.

There is a disconnected supply air duct hanging into Space 64 , Room $405 \mathrm{C}$ in the Treatment Area. This duct should be reconnected.

\section{Task 3: Airflow Measurements}

The third task of the NIST investigation of indoor air quality in the Radiation Oncology Branch involved the evaluation of the facility's ventilation and airflow characteristics. The ventilation and air movement characteristics of the ROB were investigated to compare the ventilation rates in this space to the design values and to current standards and guidelines. Other aspects of the ventilation evaluation addressed concerns about air movement between the zones of the building and the associated transport of pollutants. The measurements of ventilation system performance and air movement patterns in this facility employed several different measurement techniques to examine different aspects of the building's ventilation characteristics including airflow rates in ducts, out of diffusers, and into grilles and the percent of outdoor air being brought into the building. Tracer gas techniques were used to measure some of the above quantities and to study the movement of air between zones of the building, the entrainment of building exhaust air, and the flow of air into the building from locations outside of the building.

The measurements of airflow rates and air exchange characteristics in the $R O B$ revealed some significant differences between the system design and its actual performance, as well as other important factors related to air exchange and air movement in the facility.

The measurements of the Treatment Area air handling system showed that the supply airflow rate was close to its design value, the exhaust fan airflow rate was about $1300 \mathrm{cfm}$ (14\%) below design, and the return fan was about $1400 \mathrm{cfm} \mathrm{(32 \% )}$ above design. These differences cause insufficient exhaust airflow rates from some of the rooms of the Treatment Area and excessive return airflow rates from others. Such a situation could lead to ineffective removal of contaminants from the spaces with low exhaust airflow rates. In rooms with high return airflow rates, air could flow into the rooms from the surrounding areas, potentially bringing contaminants into these spaces. The measurements also showed that the outdoor air intake rate for the Treatment Area was about $1900 \mathrm{cfm}(20 \%)$ below the minimum intake design value, and it was always operating at minimum intake 
during the measurements. A significant amount of duct leakage was noted in the air handling system: supply air $18 \%$, exhaust air $16 \%$, and return air $28 \%$. Air leakage in the supply air duct results in lower airflows to individual rooms, including lesser amounts of outdoor air. The return air duct leakage is a matter of particular concern because this leakage presumably occurs in spaces such as ceiling plenums, service chases, and equipment rooms. These spaces are generally quite dirty and the air that leaks into the return ducts from these spaces is recirculated into the supply airflow, along with any contaminants picked up in these spaces.

The measurements of mechanical ventilation airflow rates in the individual rooms of the Treatment Area revealed many differences between design and actual airflow rates. At least some of these differences are due to the differences between the actual and design airflow rates of the return and exhaust fans. In particular the ventilation airflow rates to Linacs \#1 through \#3 and to the Simulator are well below their design values. The central offices and examination rooms in the Treatment Area have excessive return airflow rates, although the design calls for a balance of the supply and return ventilation airflow rates in these rooms.

The supply fan serving Levels $\mathrm{B} 3 \mathrm{~B}$ and $\mathrm{B} 2.5 \mathrm{~B}$ has an airflow rate that is about $30 \%(3200 \mathrm{cfm})$ above its design value. The exhaust air system is moving about $1000 \mathrm{cfm}$ less than design. There is also a significant amount of duct leakage in these two systems, about $40 \%$ in each. As in the Treatment Area, there are many rooms on these two levels with significant differences between the design and measured airflow rates at the supply diffusers and the exhaust grilles. The southeast portion of Level B3B tends to have low exhaust airflow rates compared to design, as does the entire west side of Level B2.5B. Most of the rooms on the west side of Level B3B have higher supply airflow rates than design. Three rooms on Level B3B-West have such high supply airflows rates that the occupants have attempted to block off the diffusers. Most of the laboratories on these two levels are at a positive pressure relative to the hallway because of the excessive supply airflow rates. Some of these cases of oversupplied laboratories are presumably due to the modification of the supply air fan without an accompanying change in the exhaust air system. This situation leads to contaminant transport from the laboratories to the hallway, where building occupants, including patients on their way to the Treatment Area, are exposed to these substances.

On Level 1B, many differences were detected between the design and actual ventilation airflow rates to and from individual rooms. The exhaust airflow rates were low on the east side of the floor, particularly in the southeast corner. The mould room has an insufficient exhaust airflow rate, leading to the transport into the hallway of the substances associated with the mould-making process. Some of the 
laboratories on this level have an excess of supply air, leading to airflow into the hallway. Many of the room exhaust airflow rates are low because of a large hole in the exhaust duct and an old exhaust grille located above the ceiling.

Tracer gas and smoke tests were conducted to examine interzone air movement and the entrainment of exhaust air into the building air intakes. Within the $R O B$, air flows from the Treatment Area to the Level B3B hallway, and the air from all three of the $B$ corridor hallways flows into the stair and elevator shafts. These shafts are depressurized relative to the ROB space presumably because of large mechanical exhaust airflow rates on the other floors of the $B$ corridor and the rest of Building 10. Air is being pulled from these shafts on these other floors, causing the shafts to be at significant negative pressures relative to the floors of the ROB.

The movement of air, and potentially contaminants, into the ROB from several outdoor pollutant sources was examined with tracer gas testing. These tests showed that there was airflow from the loading dock by stair \#5 to Level 1B, presumably via the freight elevator shaft. Airflow from the cafeteria loading dock to the Treatment Area was also identified, with lesser amounts of airflow to Levels 1B, $\mathrm{B} 2.5 \mathrm{~B}$ and B3B. Treatment Area exhaust air was also observed to flow into the occupied space of the Treatment Area. Some of the Treatment Area exhaust air was also seen in the rest of the ROB. Entrainment of exhaust air from the numerous exhaust air systems on the roof of the B corridor was also examined. Tests of an exhaust outlet pointing upward from the building showed that this outlet design did not result in significant exhaust air entrainment by the $\mathrm{B}$ corridor air handling systems. Tests of an outlet pointing downward revealed significant amounts of entrainment, enabling contaminant transport to the occupied space of the $\mathrm{B}$ corridor.

The ventilation evaluation of the ROB uncovered differences between the design and actual airflow rates in the air handlers serving the facility as well as differences in the ventilation airflows to and from individual rooms. These differences contribute to many of the laboratories being at a positive pressure relative to the hallway, creating the possibility for contaminant transport from the laboratories into the hallways. In addition, significant amounts of duct leakage were noted in several of the air handling systems. Tracer gas and smoke visualization tests demonstrated the potential for significant air movement and contaminant transport within the building and from outdoor pollutant sources (including exhaust airstreams) to spaces in the ROB. 


\section{Task 4: Contaminant Measurements}

The fourth task of the NIST evaluation of indoor air quality in the ROB involved the measurement of contaminant levels within the facility. The pollutants that were studied include carbon dioxide, carbon monoxide, formaldehyde, radon, respirable particulates, and volatile organic compounds. In order to evaluate the thermal comfort within the facility, temperature and relative humidity were also monitored. The measurement of contaminant levels in the ROB did not reveal any excessive concentrations relative to ASHRAE Standard 62.

The carbon dioxide concentrations within the ROB were well within ASHRAE recommendations and were consistent with the measured ventilation rates and building occupancy levels. Some spaces were at higher levels than the rest of the facility, including the nurses station in the Treatment Area and the conference room on Level B2.5B. These elevated levels, while not a matter of concern in and of themselves, do indicate a lower ventilation rate relative to the number of occupants than elsewhere in the facility.

No significant concentrations of carbon monoxide were measured in the facility, with the CO levels well within the ASHRAE recommendations (based on EPA ambient air quality standards). These measurements were made on only a limited number of occasions, and therefore these low readings are not inconsistent with occasional complaints about motor vehicle exhaust fumes in the space.

The measured levels of both formaldehyde and radon were very low throughout the ROB. In both cases the concentrations were at or below the minimum detectable limit of the measurement devices and well below the ASHRAE recommendations for indoor levels.

The measured concentrations of airborne particulates were generally low in the facility, at levels typical for office spaces. The particulate concentrations measured in an office on Level B2.5B with the light-scattering particle counter were significantly higher than levels we have measured in other office spaces. Although there is no reliable conversion from particulate concentrations to mass units, the results in this room appear to be on the order of magnitude of the maximum levels in ambient air quality standards. Additional measurements were made in this same space using an aerosol mass monitor and the readings were low, indicating that the high levels obtained with the particle counter do not always exist and may have been associated with a particular event within or outside of the building and airflow patterns that transported the particulate matter into the space. These results merit further study as to prevalence of these high levels and the composition of the particulate matter.

The evaluation of volatile organic compounds (VOC) in the ROB identified 
some light aromatic hydrocarbons, along with other substances. All were at very low levels, and some were quite close to the outdoor concentrations suggesting that there are no indoor sources for those particular substances. All of the measured concentrations were several orders of magnitude below the OSHA limits for the workplace. They were also quite low in comparison to suggested levels for the total VOC burden for nonindustrial buildings. These results, though quite low, are only relevant to the time at which the measurements were made. VOC levels could certainly be higher at other times. For example, if there were an inadvertant chemical release in or near the building, the interzone airflows prevalent in this facility could lead to significant transport of contaminants within the facility and elevated concentrations.

The evaluation of thermal comfort in the facility revealed several spaces with conditions that were not conducive to occupant comfort. Cases of both very warm and very cold rooms were found. Generally low levels of relative humidity prevailed throughout the space. There appears to be deficiencies in the HVAC controls for the facility that lead to these uncomfortable conditions.

\section{Task 5: Recommendations}

The air quality investigation of the Radiation Oncology Branch at the National Institutes of Health has not revealed any critical air quality problems in terms of high pollutant levels or low ventilation rates. Both the measured pollutant levels and the ventilation rates were generally in agreement with the ASHRAE air quality standard and the HHS construction guidelines. However, several deficiencies were identified which could be responsible for some of the air quality complaints that have been expressed by the occupants of the ROB. This section summarizes these deficiencies and contains recommendations for their remediation.

Tasks 1 and 2, the ventilation system design review and inspection, revealed the following deficiencies that should be corrected.

- The design documentation for the ROB mechanical ventilation systems, and indeed the entire $\mathrm{B}$ corridor, needs to be updated. It was difficult to evaluate several aspects of the ventilation system design of the facility because current design information was not available. In particular, there was no up-to-date information on the $B$ corridor ventilation system for use in understanding the relation of the ROB facility to the airflow patterns of the entire corridor. Mechanical drawings of the air distribution systems, fan schedules, and design airflow rates should be developed for the ROB, as well as for the rest of the B corridor.

- The analysis of the ventilation system design did reveal several instances in which the design deviated from current ASHRAE and HHS design guidelines. For example, there is no provision for outdoor air supply to the Treatment Area 
reception area. In addition, one copy room has no mechanical ventilation and another is connected to the return air system when it should be exhausted to the outdoors. Several of the laboratory spaces have an excess of supply airflow over exhaust air when they should be exhausted. The ventilation system design should be changed to correct these deficiencies, and the equipment and components should be modified accordingly.

- The inspection of the ROB ventilation system revealed several items that should be repaired. Damaged or missing ceiling tiles need to be replaced. The fan coil units in Linacs \#1 through \#3 are pulling air from the ceiling plenum when they should be drawing air from the occupied space. There are holes in the general exhaust duct serving Level $1 \mathrm{~B}$, reducing the exhaust airflows from the occupied space, and these should be repaired.

- The controls of the smoke/fire dampers in the Treatment Area need to be evaluated to prevent unintentional closing of these dampers and to facilitate the prompt identification of such closings. When the investigation of the ROB began several of these dampers were closed, leading to undesirable air exchange conditions in many locations in the Treatment Area. They were reopened when we notified the maintenance staff, but it is important to prevent future damper closings and to identify them when they occur. A procedure for checking damper positions needs to be developed and implemented.

Tasks 3 and 4 involved physical measurements of the airflow rates and contaminant levels within the ROB. These measurements revealed the following deficiencies in the performance of the ventilation systems which should be corrected.

- The air handling systems throughout the entire $R O B$ are in need of balancing. Fan airflow rates, as well as airflow rates to and from individual rooms, are in many instances quite different from their design values. Some of these circumstances are more critical than others, but all of them should be corrected. The specific areas requiring attention are listed in the section on Task 3.

- A significant amount of duct leakage was identified in the air handling systems, and this needs to be repaired. This duct leakage is leading to some of the differences between measured and design airflow rates to individual rooms. The leakage in the Treatment Area return air duct is of particular concern because the air flowing into this duct is recirculated into the supply air for this space.

- Conditions of poor thermal comfort were identified in several rooms within the $R O B$, including spaces that were too hot and others that were too cold. In addition, the relative humidity within the space was generally quite low. Again, notification of the maintenance staff of the low humidity levels in the Treatment Area led to an improvement in the conditions. There is still a need to evaluate the HVAC controls 
for the ROB, including an analysis of the thermal loads within the spaces. Thermal comfort parameters outside of the recommended limits are almost certainly responsible for some of the complaints and need to be improved.

In addition to the above deficiencies, Tasks 3 and 4 efforts also revealed the importance of interzone airflows and contaminant transport in this building. Interzone airflow and contaminant transport are very important air quality issues for the $R O B$ given the range of activities and associated substances occurring in and near the building. Interzone airflows were shown to exist, creating the potential for contaminant transport within the building and from sources outside of the building. The close proximity of different space types, such as patient care areas and laboratories, is an inherently difficult situation even under ideal circumstances. It is difficult if not impossible to isolate these different activities in terms of airflow, and the only way to eliminate contaminant transport between these spaces is to prohibit their existence in the same building. Similarly, pollutant sources located outside of the building also make interzone airflow an indoor air quality problem, and the only way to eliminate the contaminant transport is to remove the contaminants. Factors contributing to the interzone airflow and contaminant transport problems, and recommendations for their remediation, are discussed below.

- The interzone airflow situation in this building is complicated by the fact that when the supply fan serving Levels B2.5B and B3B was modified, increasing the supply air flow rate, there was no corresponding change to the exhaust airflow rates. This "unbalanced" modification resulted in these zones having a significantly larger amount of supply air relative to exhaust, causing many of the laboratory spaces to be at a positive pressure relative to the hallway. Air should be flowing into the laboratories from the hallways, not the other way around. The hallway on Level B3B is used to transport many patients to the Treatment Area and they will be exposed to the substances migrating from these laboratories on their way to the Treatment Area. The direction of the airflows between these laboratories and the hallway should be corrected, and this can be done by increasing the exhaust airflow rate from Levels $\mathrm{B} 3 \mathrm{~B}$ and $\mathrm{B} 2.5 \mathrm{~B}$. It is not clear, however, how an increase in the exhaust airflow rate for these zones would affect the interzone airflow patterns in the building. Currently, air is flowing from these levels, into the stair and elevator shafts, and then to some of the upper floors of the building. Increasing the exhaust airflow from Levels B3B and B2.5B could reverse these patterns, pulling air into these levels from the stair and elevator shafts. Contaminants from other areas in the building could then be transported to the ROB.

- The numerous exhaust systems for the B corridor, and the configuration of their outlets, presents an undesirable situation. Many of these outlets are pointing down, resulting in the entrainment of contaminated exhaust air by the B corridor air intakes. Such entrainment has been demonstrated and could present a serious 
problem depending on the substances being exhausted at a particular time. The exhaust system situation on the B corridor roof needs to be evaluated using stateof-the-art recommendations regarding outlet design and outlet velocities.

- There are many contaminant sources located within the building and outside of the building including trash dumpsters in the freight elevator lobbies and outside of the loading docks and motor vehicles which idle at the loading docks. Contaminants from these sources are able to migrate into the occupied space of the building causing odor problems and the potential for more significant contaminant exposures to the building occupants. Since it is not possible to eliminate the airflow transporting these contaminants, these sources should be removed. Trash should not be stored within the building, trash dumpsters should not be located close to the building, and motor vehicles should not be operating at or near the building loading docks. The use of an off-site receiving and trash facility, in conjunction with electric carts to transport material to and from the building, would eliminate the source problem. 


\section{ACKNOWLEDGMENTS}

This work was supported by an interagency agreement between the Center for Building Technology at the National Institute of Standards and Technology and the Division of Engineering Services at the National Institutes of Health. The authors wish to acknowledge the assistance of Kenneth Brow, Kenneth Waddell and Paul Hawver of NIH as well as the cooperation of the staff of the Radiation Oncology Branch. 
INTRODUCTION

Facility Description

Indoor Air Quality Complaints

TASK 1: REVIEW OF CURRENT DESIGN.

Sources of Information. . . . . . . . . . . . . . . . . . . . . 3

Ventilation System and Space Descriptlon . . . . . . . . . . . . . 5

Discussion of Ventilation System Design . . . . . . . . . . . . . . . 8

Zonal Airflow Rates. . . . . . . . . . . . . . . . . . . . . . . 8

Room Airflow Rates. . . . . . . . . . . . . . . . . . . . . . . 11

Summary of Task 1 Findings. . . . . . . . . . . . . . . . . . . . 15

TASK 2: ON-SITE INSPECTION . . . . . . . . . . . . . . . . . . 31

Treatment Area . . . . . . . . . . . . . . . . . . . . . . 31

Room-by-Room Inspection . . . . . . . . . . . . . . . . . . . . . 34

Summary of Task 2 Findings. . . . . . . . . . . . . . . . . . . . . 39

tAsk 3: Ventilation eVAluation . . . . . . . . . . . . . . . . . 41

Measurement Procedures . . . . . . . . . . . . . . . . 41

Tracer Gas Measurement System . . . . . . . . . . . . . . . 42

Airflow Rates . . . . . . . . . . . . . . . . . . . . . . . . . 42

Zone-to-Zone Communication and Exhaust Entralnment . . . . . . . . 45

Measurement Results . . . . . . . . . . . . . . . . . . . . . . 46

Zonal and Room Airflow Rates. . . . . . . . . . . . . . . . . . .46

Zone-to-Zone Communication and Exhaust Entralnment . . . . . . . . 51

Summary of Task 3 Findings. . . . . . . . . . . . . . . . . . . . . 56

TASK 4: CONTAMINANT MEASUREMENTS. . . . . . . . . . . . . . . 91

Measurement Procedures . . . . . . . . . . . . . . . . . . . 91

Results and Dlscussion . . . . . . . . . . . . . . . . . . 94

Summary of Task 4 Findings. . . . . . . . . . . . . . . . . . . . .99

TASK 5: RECOMMENDATIONS . . . . . . . . . . . . . . . . . . .111

REFERENCES . . . . . . . . . . . . . . . . . . . . . .115 


\section{List of Tables}

Page

Table 1.1a

Treatment Area (Zone \#1a) Ventilation Specifications

Table 1.1b

Treatment Area (Zone \#1b) Ventilation Specifications

Table 1.1c

Treatment Area (Zone \#1c) Ventilation Specifications

17

Table 1.1d

Treatment Area (Zone \#1d) Ventilation Specifications

Table 1.1e

Treatment Area (Zone \#1e) Ventilation Specifications

18

Table 1.2

Level B3B (Zone \#2) Ventilation Specifications

19

Level B2.5B (Zone \#3) Ventilation Specifications

Level 1B (Zone \#4) Ventilation Specifications 21

Table 1.4

Modified Level B3B (Zone \#2) Ventilation Specifications

22

Modified Level B2.5B (Zone \#3) Ventilation Specifications 23

Table 1.6

Table 1.7

Zonal Airflows and Fan Specifications

24

Table 1.8

B Corridor Ventilation Specifications

25

Air Sample Locations $\quad 60$

Table 3.1

System Airflow Rates for Treatment Area

61

Measured Room Airflow Rates in Treatment Area (Zone \#1a) 62

Table 3.3a

Table 3.3b

Measured Room Airflow Rates in Treatment Area (Zone \#1b)

63

Measured Room Airflow Rates in Treatment Area (Zone \#1c)

64

Measured Room Airflow Rates in Treatment Area (Zone \#1d)

65

Table 3.3d

Measured Room Airflow Rates in Treatment Area (Zone \#1e)

66

Summary of Airflow Rate Measurements in Treatment Area 67

System Airflow Rates for Zones \#2 and \#3

68

Measured Room Airflow Rates on Level B3B (Zone \#2) East 69

Measured Room Airflow Rates on Level B3B (Zone \#2) West 70

Measured Room Airflow Rates on Level B2.5B (Zone \#3) East 71

Measured Room Airflow Rates on Level B2.5B (Zone \#3) West 72

Summary of Airflow Rate Measurements on Levels B3B and B2.5B 73

Measured Room Airflow Rates on Level 1B (Zone \#4) 74

Daily Peak $\mathrm{CO}_{2}$ Concentrations $\quad 101$

Measured Formaldehyde Concentrations $\quad 102$

$\begin{array}{ll}\text { Measured Radon Levels } & 103\end{array}$

Results of Particulate Measurements $\quad 104$

$\begin{array}{lr}\text { Results of VOC Measurements } & 105\end{array}$

$\begin{array}{ll}\text { Results of Temperature Survey } & 106\end{array}$

$\begin{array}{ll}\text { Results of Temperature and Humidity Survey } & 107\end{array}$ 


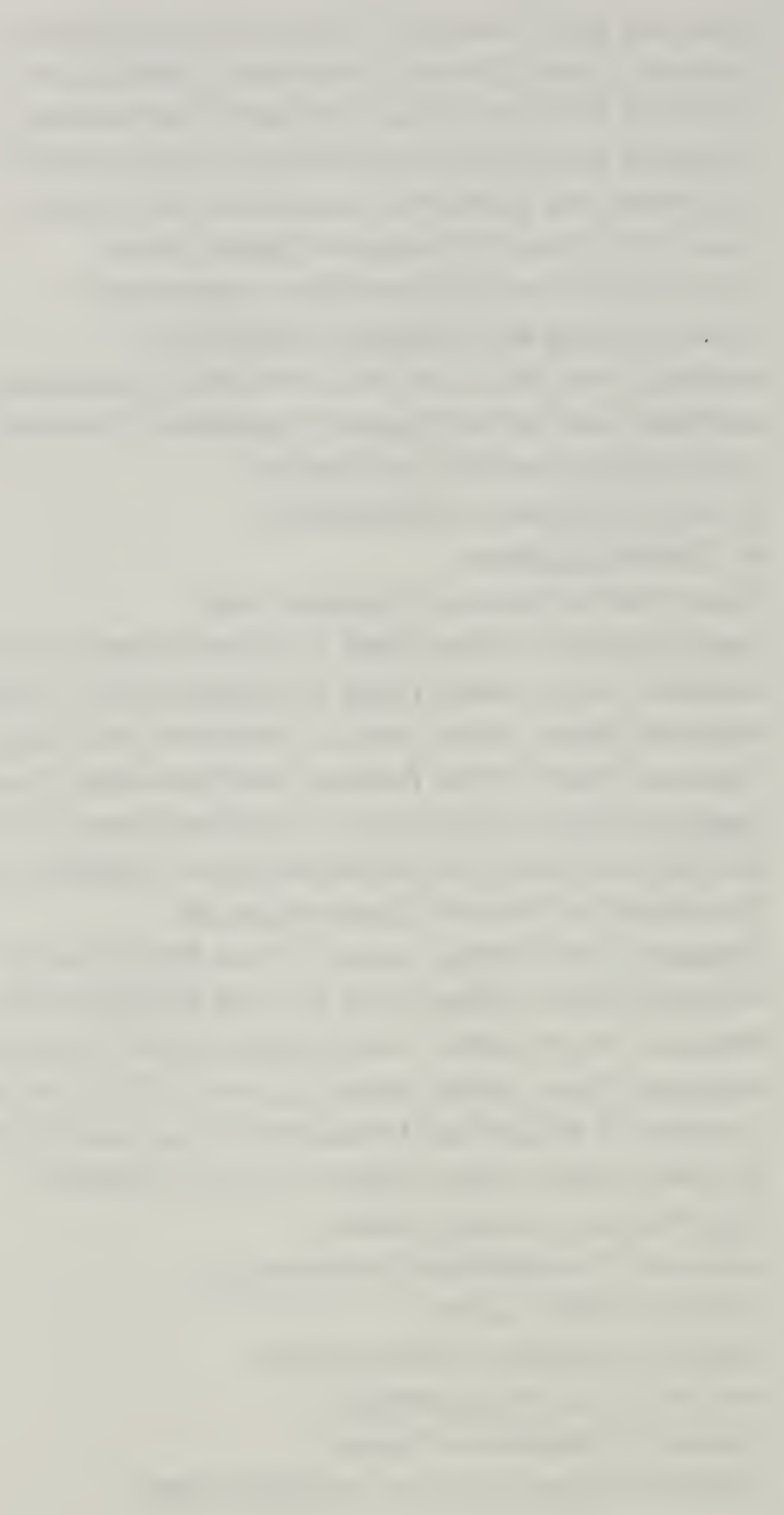




\section{List of Figures}

Figure 1.1

Figure 1.2

Figure 1.3

Figure 1.4

Figure 1.5

Figure 2.1

Figure 3.1

Figure 3.2

Figure 3.3

Figure 3.4

Figure 3.5

Figure 3.6

Figure 3.7

Figure 3.8

Figure 3.9

Figure 3.10

Figure 3.11

Figure 3.12

Figure 3.13

Figure 3.14

Figure 3.15

Figure 4.1

Figure 4.2
Schematic of $B$ Corridor and ROB in Building 10

26

Floor Plan of Treatment Area (Zone \#1)

Floor Plan of Level B3B (Zone \#2)

28

Floor Plan of Level B2.5B (Zone \#3)

29

Floor Plan of Level 1B (Zone \#4)

30

Actual Ductwork Layout in Linac \#4 Area

40

Percent Outdoor Air Intake vs. Outdoor Temperature

75

Measured Airflow Rates in Treatment Area (Zone \#1)

76

Measured Airflow Rates in Level B3B (Zone \#2)

77

78

Measured Airflow Rates in Level B2.5B (Zone \#3)

79

Tracer Gas Injection in Treatment Area

80

Tracer Gas Injection in Level B3B and B2.5B Supply Duct

81

Tracer Gas Injection in 1B Hallway

82

Airflow Patterns from Smoke Tests

83

Results of Stairwell Smoke Tests

84

Schematic of Treatment Area and B Corridor

85

86

Tracer Gas Injection at Stair \#5 Loading Dock

87

88

Tracer Gas Injection at Treatment Area Exhaust

89

Tracer Gas Injection into B Corridor Exhaust

108

Carbon Dioxide Concentrations in Treatment Area

109 



\section{INTRODUCTION}

The Radiation Oncology Branch (ROB) is part of the Clinical Center at the National Institutes of Health, located in Bethesda, Maryland outside of Washington, DC. The ROB is a multi-use facility, as is the rest of the Clinical Center, including offices, laboratories and patient treatment areas. The occupants of the facility have expressed dissatisfaction with the indoor air quality for several years and the NIST investigation was intended to address this situation. This report begins with a brief introduction containing a description of the facility and a discussion of the indoor air quality complaints. The five subsequent sections discuss each of the five tasks comprising the NIST effort: (1) a review of the HVAC system design, (2) an inspection of the HVAC system, (3) a study of air exchange in the facility using tracer gas and other techniques, (4) measurement of contaminant levels in the facility, and (5) the recommendation of modifications to the facility.

\section{Facility Description}

The ROB facility is part of the Clinical Center (Building 10) at NIH and is contained within the eight story "B" corridor of the building (see Figure 1.1). The facility consists of two main sections: the Treatment Area which has a floor area of approximately $14,000 \mathrm{ft} 2$ and is located underground; and the support section with a floor area of about $18,000 \mathrm{ft} 2$, located on three different levels - two underground (Levels B3B and B2.5B) and one above ground (Level 1B). The Treatment Area and Level $B 3 B$ are at the same elevation, connected directly to each other. Level $\mathrm{B} 2.5 \mathrm{~B}$ is located directly above Level B3B, and Level $1 \mathrm{~B}$ is three floors above B2.5B. In this report, the Treatment Area is referred to as Zone \#1 and Levels B3B, $\mathrm{B} 2.5 \mathrm{~B}$ and $1 \mathrm{~B}$ are referred to as Zones \#2, \#3 and \#4 respectively. Floor plans of Zones \#1 through \#4 are shown in Figures 1.2 through 1.5.

The B corridor of Building 10 was constructed in the late 1940's, and most of the spaces within the building have been remodeled and renovated several times since then. The Treatment Area was added to the building in the late 1970's and has not changed very much since then. Levels B3B and B2.5B underwent a major renovation in 1987. Level $1 \mathrm{~B}$ has had several renovation projects over the years in different areas, the latest of these projects having just been completed. The Treatment Area is used for patient reception and examination, radiation therapy, office and computer work, and various supporting activities such as film processing. The support areas, Zones \#2 through \#4, include offices, laboratories, and other work areas.

The Treatment Area (Zone \#1) is served by an HVAC system that is located in a mechanical penthouse above the zone (see Figure 1.1). This system consists of 
an exhaust fan, a single return fan, and two supply fans which feed into a single supply air distribution system. Levels B3B and B2.5B (Zones \#2 and \#3) are served by a supply air fan installed during the 1987 renovation, located in the $B$ corridor penthouse mechanical room. Before the renovation of 1987 , this space was served by the $B$ corridor air handling system. These two floors are still served by the $\mathrm{B}$ corridor general exhaust fans. Level $1 \mathrm{~B}$ is served by the $\mathrm{B}$ corridor air handling system consisting of four supply air fans, three general exhaust fans, and numerous laboratory and fume hood exhaust fans. There are several fume hoods on $1 \mathrm{~B}$, which are connected to two dedicated hood exhaust systems. There is a supply fan on Level 1B that provides make-up air to these fume hoods.

\section{Indoor Air Quality Complaints}

The indoor air quality complaints in the ROB are of several types, including a range of thermal comfort complaints that vary with time and location. These include uncomfortable levels of air motion (too much and too little) and air temperature (too hot and too cold). Complaints about stuffiness and air distribution also exist, in that certain areas are perceived as receiving more or less ventilation air than others. Odor complaints are common, with the occupants attributing these odors to particular sources such as animal laboratories (some of which are located on Level $\mathrm{B} 2 \mathrm{~B})$, the trash bins located on various levels by the freight elevators, and trash and motor vehicles located at the loading docks on the B1 level. In addition to thermal comfort and odor complaints, there have been many complaints of typical "sick building syndrome" symptoms such as eye and respiratory irritation, often described by the occupants as "allergic" reactions. Most of the problems are reported to have started after the $\mathrm{B} 3 \mathrm{~B}$ and $\mathrm{B} 2.5 \mathrm{~B}$ levels were renovated in March of 1987. There has not been a systematic assessment of the occupants' satisfaction with the environment, and such a survey would be of value. The above description of the complaints is based on anecdotal reports by the ROB staff. 


\section{TASK 1: REVIEW OF CURRENT DESIGN}

The first task of the ROB study was to review the current design documents of the HVAC systems, conduct a detailed engineering review of the ventilation system design, and compare the design to current ventilation standards and design guidelines. As this task began, it became apparent that a complete and up-to-date description of the ROB ventilation systems did not exist, and therefore such a description had to be developed. This involved locating and collecting current floor plans and mechanical drawings, fan schedules, and other relevant documentation. This information was carefully examined for completeness and consistency to develop the following description of the ventilation systems serving the ROB.

In considering the ROB ventilation system design, it is important to keep in mind that this facility is only a portion of the larger $B$ Corridor which itself is only a portion of Building 10. Airflows between the ROB and other areas in the building may be expected to impact the air quality within the ROB. The NIH/NIST agreement involves only the ROB facility, but its relation to the rest of the building must be considered. Very little current information on the $B$ Corridor ventilation system exists, but given the potential importance of interzone airflows to and from the ROB this additional information needs to be documented in order to evaluate the $R O B$ ventilation system in the context of the whole building.

\section{Sources of Information}

Several pieces of documentation were used to develop the description of the $R O B$ ventilation system including floor plans, mechanical drawings, fan schedules, and air balance reports. The following drawings were used: 
Treatment Area

$\begin{array}{ll}6-07594 & \text { A-5 } \\ 6-07594 & \text { A-6 } \\ 6-07594 & \text { A-13 } \\ 6-07594 & \text { M-4 } \\ & \text { B3B-003 } \\ 6-07594 & \text { M-5 } \\ 6-07594 & \text { M-6 } \\ 6-07594 & \text { M-7 } \\ 6-07594 & \text { M-9 } \\ 765-68 & \text { ATC-1 } \\ 765-68 & \text { ATC-3 }\end{array}$

Floor Plan

Basement \& Tower Plans

Building Sections

Floor Plan - HVAC

Floor Plan

Parts Plan - Mechanical

Penthouse Plans \& Sections

Control \& Piping Diagrams

Schedules

AHU 1 \& 2 (Supply) Control

Misc. Controls
$12 / 77$

$12 / 77$

$12 / 77$

$12 / 77$

$8 / 77$

$8 / 77$

$12 / 77$

$12 / 77$

$2 / 80$

$11 / 80$

\section{B3B/B2.5B Levels}

$\begin{array}{ll}206389 & 5733 \mathrm{MP}-1 \\ 6-07594 & 5716-A 5 \\ 6-07594 & 5716-A 7 \\ 6-07594 & 5716-A 8 \\ 6-07594 & 5716-A 9 \\ 6-07594 & 5716-A 10 \\ 6-07594 & 5716-M-1 \\ 6-07594 & 5716-M-2 \\ 6-07594 & 5716-M-9\end{array}$

Renovate Rm B3B56A - Mechanical

$9 / 82$

Floor Plan - Level B3B

$1 / 85$

Floor Plan - Level B3B South

$1 / 85$

Floor Plan - Level B3B North

$1 / 85$

Floor Plan - Level B2.5B South $\quad 1 / 85$

Floor Plan - Level B2.5B North $\quad 1 / 85$

Level B3B - HVAC $\quad 11 / 85$

Level B2.5B - HVAC $\quad 11 / 85$

Schedules \& Details $\quad 1 / 85$

1BLevel

$\begin{array}{ll}206389 & 10-A-B-100 \\ 206389 & 5733 A-1 \\ 206389 & 5733 A-2 \\ 206389 & 5733 A-3 \\ 206389 & 5733 \mathrm{M}-1 \\ 206389 & 5733 \mathrm{M}-2 \\ 206389 & 5733 \mathrm{M}-3 \\ 206389 & 5733 \mathrm{M}-4 \\ 701882 & \\ 701882 & \\ 701882 & \\ 701557 & \mathrm{M} 1 \\ 705370 & \end{array}$

Bldg.10, 1st Floor Plan

$9 / 68$

Renovate 1B Corridor - Demolition $\quad 9 / 82$

Renovate 1B Corridor - Part A New Work $\quad 9 / 82$

Renovate 1B Corridor - Part B New Work $\quad 9 / 82$

Renovate 1B Corridor - Sections \& Details $\quad 9 / 82$

Renovate 1B Corridor - Demolition $\quad 9 / 82$

Renovate 1B Corridor - Demolition $\quad 9 / 82$

Renovate 1B Corridor - Part A New Work $\quad 9 / 82$

Renovate 1B Corridor - Part B New Work $\quad 9 / 82$

Modify Room 1 B50 $\quad 4 / 87$

Renovate Room $1 B 46 \quad 4 / 87$

Renovate 1B Corridor $\quad 4 / 87$

Renovate Rooms $1 \mathrm{B34} \& 1 \mathrm{~B} 40 \quad 7 / 87$

Install Exhaust Risers - Wing-B - Mech-Arch $\quad 12 / 87$

BComidor

Bldg. 10 Partial Low Pressure Air Handling Unit Schedule - Corrective Work Fumehood Study - Bldg. 10 - Scheme I Riser Diagram Wing C

$18-063$

$9-\mathrm{H}-42$

Sixth Floor Plan Unit "C" 
The following balance reports were used:

Company

Comfort Control Inc.

Comfort Control Inc.

Comfort Control Inc.

Comfort Control Inc.

Wendes Engineering and

Contracting Services

Comfort Control Inc.
Area or Fan Tested

Date

B3B/B2.5B Supply Vents

$3 / 87$

B3B/B2.5B Supply Fan

$3 / 87$

$B 3 B / B 2.5 B$ Exhaust Vents

B3B/B2.5B Exhaust Fan

$4 / 87$

B3B/B2.5B Supply Fan

$4 / 87$

$6 / 87$

B3B/B2.5B Supply Fan

In addition to these drawings and balance reports, the ROB ventilation system description is based on visual inspections of the equipment and spaces, as well as discussions with building engineering staff.

\section{Ventilation System and Space Description}

This section presents the description of the ROB facility and its ventilation system developed in Task 1. It is presented in tabular form in Tables 1.1 through 1.5 and in schematic form in Figures 1.2 through 1.5. The tables list, for each zone, the spaces or rooms within that zone, their floor areas and volumes, and the supply, exhaust and return design airflow rates for each room in cubic feet per minute (cfm). Each room is associated with a space number that comes from the building plans, as well as a room number. The net airflow rates to or from each room (supply minus exhaust minus return) are also given, as well as the design air change rate of each room. The design air change rate in units of air changes per hour is equal to the total mechanical airflow into or out of the room (whichever is larger) divided by the room volume. Table 1.1, describing the Treatment Area, also contains the design values for the minimum outdoor air intake rate for each room. The values in parentheses in Table 1.1 are the design minimum outdoor air intake rate for each room in air changes per hour, when applicable. In Tables 1.2 through 1.4 the value in parentheses is the design air change rate based on the supply airflow rate, only if different from the design rate based on the larger of the supply and exhaust airflow rates for the room. Figures 1.2 through 1.5 are schematic floor plans of the four zones of the ROB, providing some descriptive information on space use. The number in the upper left hand corner of each room corresponds to the space number in the tables. Table 1.1 and Figure 1.2 describe Zone \#1, the Treatment Area, which is arbitrarily divided into five sections (\#1a through \#1e) for ease of presentation. Tables 1.2 through 1.4 describe Zones \#2 (Level B3B), \#3 (Level B2.5B) and \#4 (Level 1B), respectively. 
The Treatment Area is unique in that it is the only zone within the ROB with a return air system, enabling the recirculation of return air from the occupied space. This return air is drawn primarily from the office space within the Treatment Area. According to the ventilation system description in the fan schedules, the amount of return air that is mixed with the supply air ranges from none, under $100 \%$ outdoor air intake conditions, to more than $4000 \mathrm{cfm}$ under minimum outdoor air intake conditions. The design minimum outdoor air intake rate is $9400 \mathrm{cfm}$ (as shown in Table 1.7) corresponding to 3.1 air changes per hour of outdoor air. Under $100 \%$ outdoor air intake, all of the supply air is outdoor air (about 14,000 cfm) and both the exhaust airflow $(9300 \mathrm{cfm})$ and the return airflow $(4400 \mathrm{cfm})$ are exhausted to the outdoors. All of the other zones of the ROB run at $100 \%$ outdoor air intake all of the time with no capability of recirculating any return air.

Another unique feature of the Treatment Area ventilation system is the existence of smoke/fire control dampers and inlet dampers in the ventilation system ductwork. The smoke/fire control dampers are thermally fused to close in the event of a fire and are located in the supply, exhaust and return ductwork at points where this ductwork crosses the major interior partitions (smoke barriers) in the space. When one of these dampers does close, it must be reopened and refused manually. There are about 20 of these smoke/fire control dampers in the Treatment Area. The inlet dampers are located in the supply ductwork and are designed to close when one of the two supply fans stops operating, in order to assure that supply air gets to critical areas. These dampers close when pressure sensors in the supply ductwork sense the drop in static pressure that occurs when one of the supply fans shuts down. There are about 15 such inlet dampers, located upstream of areas which are deemed to be less critical than patient treatment areas, e.g. conference rooms and some staff areas.

Tables 1.2 and 1.3 and Figures 1.3 and 1.4 describe Zones \#2 and \#3 (Levels $\mathrm{B} 3 \mathrm{~B}$ and $\mathrm{B} 2.5 \mathrm{~B}$ ) respectively. These two floors are served by a single supply fan that was installed during the 1987 renovation and the $B$ corridor general exhaust system. There is one fume hood on B3B and two on B2.5B that are connected to a fume hood exhaust system. The airflow rates for Zones \#2 and \#3 in Tables 1.2 and 1.3 reflect the original design of the 1987 renovation. Shortly after the renovation of these two floors, the supply fan for this space was replaced, or modified, to provide a larger airflow rate. The renovation originally called for a supply airflow rate of $7570 \mathrm{cfm}$, and the modification increased this to $11,000 \mathrm{cfm}$. It is not clear exactly why this change was made; several explanations have been given. One explanation is that additional airflow was required for the proposed renovation (not yet begun) of the large space in the southwest corner of Levels B3B and $\mathrm{B} 2.5 \mathrm{~B}$. Another explanation is that the original supply airflow rate did not provide sufficient ventilation airflows to many rooms on these two floors and the 
larger airflow rate was needed to correct these deficits. Regardless of the reason for the change, when the supply airflow rate was increased to $11,000 \mathrm{cfm}$, there was no corresponding change in the design airflow rates for the supply air diffusers for these two floors. Since the supply air fan now moves $3430 \mathrm{cfm}$ more than it did originally, it is clear that these design airflow rates need to be updated. When the change in the supply fan was made, there was no corresponding change in the exhaust airflow rates. With the supply airflow rate increased by $45 \%$, it is therefore not clear how much of the additional supply air is moving through the exhaust air system and how much is moving to other portions of the building. Tables 1.2 and 1.3 provide the design airflow rates for each room on Levels $\mathrm{B} 3 \mathrm{~B}$ and $\mathrm{B} 2.5 \mathrm{~B}$, based on the original supply airflow rate of $7570 \mathrm{cfm}$. Tables 1.5 and 1.6 present these room airflow rates using the new supply airflow rate of $11,000 \mathrm{cfm}$. In these "modified" tables, the supply airflows for each room are simply the original airflow rates multiplied by 1.45 and the exhaust airflow rates are left "as is."

Table 1.7 summarizes the airflow rate design information for each zone, listing the total floor areas, volumes, and design airflow rates for each zone. These zonal airflow rates are simply the sums of the airflow rates for all of the supply air diffusers and exhaust (return) air registers in each zone. Zones \#2 and \#3 are combined since they are served by a single air handling system. The design airflow rates for the fans serving the Treatment Area and Levels B3B and B2.5B are also given for comparison to the sums of the diffuser and register design values. Both the original and modified versions of the Level $\mathrm{B} 3 \mathrm{~B}$ and $\mathrm{B} 2.5 \mathrm{~B}$ information are given in this table. The design values for the fan airflow rates agree with the sum of the diffuser and register airflow rates for Zones \#1 through \#3. No design values for the system airflow rates for Level $1 \mathrm{~B}$ are available.

As mentioned above, there is little or no documentation on the B Corridor ventilation system. Table 1.8 summarizes the information that has been located, some of which is almost 40 years old. This table shows the supply and exhaust design airflow rates for each floor based on an old riser diagram, but this information is clearly out of date and incomplete. The table does not include numerous fume hood exhausts, particularly on the fifth floor. Also, since this riser diagram was developed a new supply fan (\#18A) has been added, Level B3B has been renovated into two levels (B3B and $\mathrm{B} 2.5 \mathrm{~B}$ ), and a separate supply fan has been installed for these two levels. Two recent balance reports on fans \#18 and \#19 show their design airflow rates, but no recent information is available for any of the other fans nor for any of the individual floors. Such information could be developed from mechanical drawings for individual floors, but this would require a long and involved process that was not part of the current NIH/NIST agreement. However, supply and exhaust airflow rates for individual floors are crucial in 
understanding the movement of air between the ROB and the rest of the B-corridor, and between the B-corridor and the rest of Building 10 .

\section{Discussion of Ventilation System Design}

The airflow rates presented above are based on the ventilation system design, and the actual airflow rates in the building may be different from these design values. Experience in many other buildings indicates that the actual system airflow rates are often significantly different from their design values and that envelope infiltration (leakage) and airflows from other building zones often play important roles in the air exchange and air movement characteristics of mechanically ventilated buildings [Persily and Grot 1985a and 1985b, Persily and Norford 1987]. The ventilation system design for the $R O B$ is discussed and compared to standards and guidelines below, but one must bear in mind that the system design does not necessarily reflect the actual ventilation performance of these spaces. The aim of Task 1 is to evaluate only the design of the ROB ventilation system. Actual performance issues will be considered in other tasks. Specifically, Task 2 addresses the installation of the ventilation system and its current condition, and Task 3 involves the measurement of airflow rates.

The discussion of the ventilation system design does not reflect the existence of a small number of supply diffusers and exhaust registers in the space that are not on the mechanical drawings. These additional fixtures were noted during the Task 2 inspection and are itemized later in this report. Since they do not appear on any of the available mechanical drawings, there is no way of knowing the design airflow rate associated with each.

The ROB ventilation system design is discussed below in terms of the zonal airflow rates and the airflow rates for individual rooms. The zonal airflow rates, presented in Table 1.7, reflect the total mechanical aiflow rates to or from each of the zones and are discussed below in relation to the movement of air between these zones and other zones of the building. The individual room airflow rates in Tables 1.2 through 1.6 are then discussed in relation to recommended levels of ventilation for these rooms.

\section{Zonal Airflow Rates}

Interzone airflow rates are important in the $R O B$ facility, given the need to prevent the contaminants produced within certain areas of the space from migrating to other areas. The airflow rate from one building zone (including the outdoors) to another depends on their relative air pressures and on the airtightness of the boundary between the two zones. The mechanical airflow rates to and from these zones affect their relative air pressures, and therefore the interzone airflow 
rates. By considering the mechanical airflow rates to and from each zone, we can estimate the expected air movement patterns within the building, but we must bear in mind the numerous other factors that determine the interzone airflow rates and patterns. An up-to-date version of Table 1.8 would be necessary to develop such a description of the building air movement patterns. Unfortunately, the only reliable zonal airflow information is contained in Table 1.7 for the ROB zones, and therefore our discussion must be limited in terms of how these zones may interact with each other and with other building zones.

Table 1.7 summarizes the total mechanical ventilation airflow rates into and out of each of the four ROB zones. Beginning with the Treatment Area, there is a slight excess of supply airflow to this zone, $775 \mathrm{cfm}$ according to the diffuser and register design airflow rates and $300 \mathrm{cfm}$ according to the fan airflow rates. If these design airflow rates were realized and there was no air infiltration though the building envelope, then the space would be under a slight positive pressure and air would tend to flow out of the zone. The Treatment Area is bounded only by the outdoors and Level B3B, and therefore the amount and direction of airflow to or from the Treatment Area also depends on its air pressure relative to these two zones. The amount of excess supply airflow is not very large (only 2 to $5 \%$ of the total supply airflow rate) relative to the expected discrepancies between design and actual mechanical airflow rates. A relatively small difference between the design airflow rates and the actual rates could result in the intended pressurization of the Treatment Area being reversed.

Level B3B is oversupplied by $500 \mathrm{cfm}$ based on the original design aiflow rates for the supply diffusers and exhaust registers. Based on this information alone, it is not clear to what zone this extra air will flow. The direction and quantity of the airflows to or from this zone depend on the exhaust airflow rate for this zone and the air pressure in this zone relative to the adjoining spaces including Zone \#1, and the stair and elevator shafts. Using the modified design airflow rates for Level B3B in Table 1.5, based on the new $11,000 \mathrm{cfm}$ supply fan airflow rate, the Level B3B oversupply increases to about $2600 \mathrm{cfm}$. This additional airflow will tend to reduce the airflow to $\mathrm{B} 3 \mathrm{~B}$ from other zones and increase the airflows out of this zone. On Level B2.5B, the "original" supply fan airflow rate leads to a very slight undersupply on this floor $(-20 \mathrm{cfm})$. The amount of undersupply is small, given the expected uncertainties in the actual airflows rates in even a perfectly installed and maintained system. According to the modified supply fan airflow rate, Level B2.5B is oversupplied by almost $1500 \mathrm{cfm}$. Level 1B is significantly undersupplied according to the design, leading to the expectation that air will flow to it from other zones. 
The zonal design airflow rates for the $R O B$ facility may be summarized as follows:

Treatment Area - This zone is slightly oversupplied by only $300 \mathrm{cfm}$ according to design. A small deviation from design or a flow imbalance in an adjacent zone (Level B3B) could result in the Treatment Area being at a negative pressure in relation to Level $\mathrm{B} 3 \mathrm{~B}$. In this situation, airborne substances generated on $\mathrm{B} 3 \mathrm{~B}$, or generated elsewhere in the building and transported to B3B, would be transported to the Treatment Area.

Level B3B - This zone is slightly oversupplied (500 cfm) according to the original supply air diffuser design. The modification of the supply airflow rate increases this oversupply significantly to about $2500 \mathrm{cfm}$. This oversupply may lead to airflow from Level $B 3 B$ to the Treatment Area or elsewhere, carrying whatever airborne substances that are produced in the B3B laboratories.

Level B2.5B - This zone is very slightly undersupplied $(-20 \mathrm{cfm})$ based on the original supply fan design, but is oversupplied by about $1500 \mathrm{cfm}$ based on the new supply fan airflow rate. This oversupply may lead to the transport of air and airborne contaminants from $\mathrm{B} 2.5 \mathrm{~B}$ to other areas in the building.

Level 1B - This zone is undersupplied (by about $1500 \mathrm{cfm}$ ). The need for air to "make up" for this exhaust flow may lead to airflows from other areas in the building to this level.

Due to the inherently complex nature of airflow between different sections of a building, it is impossible to state with certainty how the above over-and undersupplies will affect the directions and quantities of interzone airflows. Even when a zone is oversupplied in terms of mechanical ventilation airflows, it is the zone's pressure relative to any other zone that determines the direction and amount of airflow to that zone. It is not necessary for two zones to be connected by an open corridor, or other large pathway, for significant amounts of air to flow between them. There are numerous other airflow paths in this building, such as stair and elevator shafts, and plumbing, ductwork and electrical chases that connect the various floors to each other. 
Room Airflow Rates

The design airflow rates for each room in the ROB are discussed below with reference to the following standards and guidelines:

ASHRAE Standard 62-1981, Ventilation for Acceptable Air Quality, American Society of Heating, Refrigerating, and Air-Conditioning Engineers.

ASHRAE Standard 62-1981R, Draft Revision of ASHRAE Standard 62-1981, 15 December 1987.

Guidelines for Construction and Equipment of Hospital and Medical Facilities, 1983/84 Edition, DHHS Publication No. (HRS-M-HF) 84-1,U.S. Department of Health and Human Services.

These documents specify minimum amounts of outdoor air intake and total supply airflow rates for various space uses. Together they cover almost all of the space uses in the ROB. This information is contained in Table 3 (Outdoor Air Requirements for Ventilation) in ASHRAE 62-1981, Table 2 (Outdoor Air Requirements for Ventilation) in ASHRAE 62-1981R, and Table 3 (Ventilation Requirements for Hospital Areas Affecting Patient Care) in the HHS guidelines. The proposed revision of the ASHRAE Standard, 62-1981R, is expected to be published in 1989 , and the ROB ventilation system was obviously not designed with reference to this standard. It is included in this discussion in order to compare the $R O B$ design to current thinking regarding ventilation requirements. The relevant information from these three documents is summarized in the following table. For many space types the standards and guidelines specify the desired direction of air movement into (In) or out of (Out) the space in question relative to adjacent areas. In this table, the term "ach" refers to air changes per hour. All of the values from the ASHRAE standard are minimum amounts of outdoor air, while the HHS Guidelines specify total air changes, not minimum outdoor air. 


\begin{tabular}{|c|c|c|c|}
\hline Space Type & $\begin{array}{c}\text { ASHRAE } \\
62-1981 \\
\end{array}$ & $\begin{array}{l}\text { ASHRAE } \\
62-1981 R \\
\end{array}$ & $\begin{array}{r}\text { HHS 83/84 } \\
\text { Guidelines } \\
\end{array}$ \\
\hline Offices - No-Smoking & $5 \mathrm{cfm} /$ person & - & - \\
\hline Offices - Smoking & $20 \mathrm{cfm} /$ person & - & - \\
\hline Offices & - & $20 \mathrm{cfm} /$ person & - \\
\hline Meeting Spaces - No Smoking & $7 \mathrm{cfm} /$ person & - & - \\
\hline Meeting Spaces - Smoking & $35 \mathrm{cfm} / \mathrm{person}$ & - & - \\
\hline Conference Rooms & - & $20 \mathrm{cfm} /$ person & - \\
\hline Office Reception Areas & - & $15 \mathrm{cfm} / \mathrm{person}$ & - \\
\hline Darkrooms & $20 \mathrm{cfm} /$ person (In) & $0.5 \mathrm{cfm} / \mathrm{ft}^{2}(\mathrm{In})$ & 10 ach $(\operatorname{In})$ \\
\hline \multicolumn{4}{|l|}{ Duplicating and } \\
\hline Printing & $0.5 \mathrm{cfm} / \mathrm{ft} 2(\mathrm{In})$ & $0.5 \mathrm{cfm} / \mathrm{ft} 2(\mathrm{In})$ & - \\
\hline \multicolumn{4}{|l|}{ Medical Facility } \\
\hline Bathrooms & - & - & 10 ach \\
\hline \multicolumn{4}{|l|}{ Medical Facility } \\
\hline Toilet Rooms & - & - & $10 \operatorname{ach}(\ln )$ \\
\hline Patient Exam Rooms & - & - & 6 ach \\
\hline \multicolumn{4}{|l|}{ Medical Procedure Areas } \\
\hline $\begin{array}{l}\text { - No-Smoking } \\
\text { Medical Procedure Areas }\end{array}$ & $7 \mathrm{cfm} /$ person & - & - \\
\hline - Smoking & $35 \mathrm{cfm} /$ person & - & - \\
\hline Medical Procedure Areas & - & $15 \mathrm{cfm} /$ person & - \\
\hline Dirty Linen & - & - & $10 \operatorname{ach}(\ln )$ \\
\hline Clean Linen & - & - & 2 ach \\
\hline Janitor's Closet & - & - & $10 \operatorname{ach}(\operatorname{In})$ \\
\hline \multicolumn{4}{|l|}{ Laboratories } \\
\hline General & - & - & 6 ach \\
\hline Biochemistry & - & - & 6 ach (Out) \\
\hline Histology & - & - & 6 ach $(\ln )$ \\
\hline Bacteriology & - & - & 6 ach $(\ln )$ \\
\hline Serology & - & - & $6 \operatorname{ach}\left(O u^{t}\right)$ \\
\hline Glasswashing & - & - & 10 ach (In) \\
\hline Sterilizing & - & - & $10 \operatorname{ach}(\operatorname{In})$ \\
\hline
\end{tabular}

These ventilation requirements were used to evaluate the design airflow rates for each room in the ROB. Several deviations from these requirements were noted and are discussed below. As noted in the above table, the desired ventilation rate 
and direction for laboratory spaces in the HHS Guidelines depend on the type of laboratory. Most of the laboratories in the ROB can be classified as general or biochemistry, with some bacteriological activities. While these guidelines do not absolutely specify exhaust-dominated ventilation in the ROB laboratories, the nature of the activities and the associated substances suggest the need for exhaust-dominated ventilation. Therefore, laboratory spaces that are not exhaust dominated are noted as such.

\section{Zone \#1 (Treatment Area)}

Space 1, Main Reception - This large space has no provision for the supply of outdoor air. There are two fan coil units at the entrance level and three more in the ceiling, but these provide only reconditioned space air and no outdoor air. There is a small exhaust register located over a coffee bar at one end of the reception area.

Space 60, Copy Room - This area has an adequate design ventilation rate, but it is connected to the return air system instead of the exhaust system. The emissions from the copy machine are therefore recirculated into the supply air, when they should be exhausted to the outdoors (ASHRAE Standard).

\section{Zone \#2 (Level B3B)}

Space 19, Darkroom - This darkroom appears to have an adequate ventilation rate based on the original supply airflow design (5.4 ach), according to the ASHRAE Standard ( $3.8 \mathrm{ach}$ ), but inadequate according to the HHS Guidelines (10 ach). The original ventilation design for this space is balanced (supply and exhaust airflow rates are equal), but based on the modified supply airflow rate this darkroom is oversupplied by $32 \mathrm{cfm}$. The ASHRAE Standard and the HHS Guidelines recommend that darkrooms be ventilated such that there is an excess of exhaust airflow over supply airflow, preventing air movement from the darkroom to other areas.

Space 20, Glass Wash - This space is ventilated at an air change rate of 7.6 air changes per hour, but the HHS Guidelines recommend 10 air changes per hour of exhaust-dominated ventilation. In the original design the ventilation of this room is balanced. Based on the modified supply airflow rate, the air change rate of 11.1 ach is adequate but the room is oversupplied by $109 \mathrm{cfm}$.

Space 27, Tissue Culture - This space is oversupplied by $20 \mathrm{cfm}$ based on the original supply fan design and $111 \mathrm{cfm}$ based on the modified supply airflow rate.

Space 29, Work Lab - This space is oversupplied by $30 \mathrm{cfm}$ based on the original supply fan design and $161 \mathrm{cfm}$ based on the modified supply airflow rate.

Space 32, Work Lab - This space is oversupplied by $20 \mathrm{cfm}$ based on the original supply fan design and $111 \mathrm{cfm}$ based on the modified supply airflow rate. 
Space 33, Tissue Culture - The ventilation of this space is balanced based on the original supply fan design and is oversupplied by $91 \mathrm{cfm}$ based on the modified supply airflow rate.

Space 34, Tissue Culture - This space is oversupplied by $20 \mathrm{cfm}$ based on the original supply fan design and $97 \mathrm{cfm}$ based on the modified supply airflow rate.

Space 41, Laboratory - This space is oversupplied by $100 \mathrm{cfm}$ based on the original supply fan design and by $292 \mathrm{cfm}$ based on the modified supply airflow rate. An adjoining storage area (Space 44) has an exhaust airflow rate of $100 \mathrm{cfm}$, which would lead to the two rooms being balanced, but still oversupplied based on the modified supply airflow rates.

\section{Zone \#3 (Level B2.5B)}

Spaces 53 and 55, Female and Male Bathrooms - These spaces have exhaust ventilation rates of 8.3 and 7.1 air changes per hour respectively. According to the HHS Guidelines, they should be ventilated at 10 air changes per hour.

Space 64, Laboratory - This space is oversupplied by $25 \mathrm{cfm}$ based on the original supply fan design and $91 \mathrm{cfm}$ based on the modified supply airflow rate.

Space 65, Laboratory - This space is appropriately undersupplied by $150 \mathrm{cfm}$ based on the original supply fan design, but based on the modified supply airflow rate it is oversupplied by $122 \mathrm{cfm}$.

Space 66, Laboratory - This space is appropriately undersupplied by $25 \mathrm{cfm}$ based on the original supply fan design, but based on the modified supply airflow rate it is oversupplied by $77 \mathrm{cfm}$.

Space 69, Laboratory - This space is oversupplied by $175 \mathrm{cfm}$ based on the original supply fan design and $254 \mathrm{cfm}$ based on the modified supply airflow rate.

Space 70, Copyroom - This space has no mechanical ventilation at all and is open to the corridor.

\section{Zone \#4 (Level 1B)}

Space 11, Laboratory - This space is oversupplied by $200 \mathrm{cfm}$. The ventilation of this space should be exhaust dominated (HHS Guidelines).

Space 14, Janitor's Closet - This space has an exhaust ventilation rate of 6.7 air changes per hour. According to the HHS Guidelines, it should be ventilated at 10 air changes per hour. 


\section{Summary of Task 1 Findings}

Task 1 of the NIST study of the ROB facility consisted of a thorough analysis of the mechanical ventilation system design. Although not all of the system design information was available, several aspects of the design were identified that require attention as summarized below. While these items should be corrected, their impact on the air quality within the facility cannot be stated without physical measurements of the environmental conditions within the space.

The Treatment Area is only slightly oversupplied according to the ventilation system design. According to the 1983/84 HHS Guidelines this patient treatment area should be pressurized relative to adjacent areas in the building, and the amount of oversupply in the design may not be sufficient to accomplish this.

There is no outdoor air supply for the reception area in the Treatment Area.

The modification of the supply fan serving Levels B3B and B2.5B may have resulted in these spaces being pressurized. The laboratory space on these levels should be depressurized relative to adjacent areas, and the exhaust airflow rates may need to be modified to achieve this. New design values for the supply diffuser airflow rates are needed since the existing values are based on the original supply fan airflow rate.

The ventilation design airflow rates for several individual 'rooms are not in accordance with the levels of ventilation recommended by ASHRAE Standard 62 and the HHS Guidelines. There are rooms which should have exhaust-dominated ventilation, but instead they have oversupplied or balanced ventilation. Other rooms have insufficient design air exchange rates according to the HHS Guidelines. There are also problems in the two copyrooms; one has no mechanical ventilation at all and one is connected to the return air system instead of the exhaust system.

There is a need for updated versions of the mechanical drawings and design airflow rates for the ROB ventilation system that reflect the changes that have occurred in these spaces. Current information is also needed on the ventilation system design for the entire B Corridor. 
Table 1.1a Treatment Area (Zone \#1a) Ventilation Specifications

\begin{tabular}{|c|c|c|c|c|c|c|c|c|c|c|c|}
\hline \multirow[b]{2}{*}{ Space \# } & \multirow[b]{2}{*}{ Room \# } & \multirow[b]{2}{*}{ Description } & \multirow[b]{2}{*}{$\begin{array}{c}\text { Floor Area } \\
\left(\mathrm{ft}^{\wedge} 2\right)\end{array}$} & \multirow[b]{2}{*}{$\begin{array}{l}\text { Volume } \\
\left(\mathrm{ft}^{\wedge} 3\right)\end{array}$} & \multicolumn{5}{|c|}{ Design Airflow Rate (cfm) } & \multirow{2}{*}{\multicolumn{2}{|c|}{$\begin{array}{c}\text { Design Air } \\
\text { Exchange } \\
\text { Rate } \\
(1 / \mathrm{hr}) \\
\end{array}$}} \\
\hline & & & & & Supply & Exhaust & Return & Net & $\begin{array}{l}\text { Minimum } \\
\text { Outdoor } \\
\text { Air Intake }\end{array}$ & & \\
\hline 1 & & Main Reception & 1000 & 40000 & & 100 & & -100 & & 0.2 & \\
\hline 2 & & Corridor A & 866 & 14722 & 345 & & & 345 & 231 & 1.4 & $(0.9)$ \\
\hline 3 & $79 \mathrm{C}$ & Men's Toilet & 60 & 480 & & 120 & & -120 & & 15.0 & \\
\hline 4 & 75 & Men's Toilet & 71 & 568 & 60 & 160 & & -100 & 40 & 16.9 & (4.2) \\
\hline 5 & 77 & Women's Toilet & 73 & 584 & 60 & 160 & & -100 & 40 & 16.4 & (4.1) \\
\hline 6 & $79 \mathrm{~A}$ & Lockers & 131 & 1048 & 100 & & & 100 & 67 & 5.7 & (3.8) \\
\hline 7 & $79 B$ & Women's Toilet & 48 & 384 & & 120 & & -120 & & 18.8 & \\
\hline 8 & 79 & Staff Lounge & 136 & 1088 & 120 & & & 120 & 80 & 6.6 & $(4.4)$ \\
\hline 9 & 81 & Office & 66 & 528 & 60 & & 60 & & 40 & 6.8 & (4.5) \\
\hline 10 & 85 & Conference & 218 & 1744 & 225 & & 225 & & 151 & 7.7 & $(5.2)$ \\
\hline 11 & $85 \mathrm{~A}$ & Storage & 27 & 216 & & & & & & & \\
\hline 12 & & Corridor B & 184 & 1840 & & & & & & & \\
\hline 72 & 83 & Darkroom & 42 & 336 & 120 & 280 & & -160 & 80 & 50.0 & (14.3) \\
\hline
\end{tabular}

Table 1.1b Treatment Area (Zone \#1b) Ventilation Specifications

\begin{tabular}{|c|c|c|c|c|c|c|c|c|c|c|c|}
\hline \multirow[b]{2}{*}{ Space \# } & \multirow[b]{2}{*}{ Room \# } & \multirow[b]{2}{*}{ Description } & \multirow[b]{2}{*}{$\begin{array}{c}\text { Floor Area } \\
\left(\mathrm{ft}^{\wedge} 2\right)\end{array}$} & \multirow[b]{2}{*}{$\begin{array}{l}\text { Volume } \\
\left(t^{\wedge} 3\right)\end{array}$} & \multicolumn{5}{|c|}{ Design Airflow Rate $(\mathrm{cm})$} & \multirow{2}{*}{\multicolumn{2}{|c|}{$\begin{array}{c}\text { Design Air } \\
\text { Exchange } \\
\text { Rate } \\
(1 / \mathrm{hr})\end{array}$}} \\
\hline & & & & & Supply & Exhaust & Return & Net & $\begin{array}{l}\text { Minimum } \\
\text { Outdoor } \\
\text { Air Intake }\end{array}$ & & \\
\hline 13 & & Corridor C & 282 & 2820 & 350 & & & 350 & 235 & 7.4 & $(5.0)$ \\
\hline 14 & 203 & Male changing $\mathrm{rm}$. & 117 & 936 & 200 & & & 200 & 134 & 12.8 & (8.6) \\
\hline 14 & $203 \mathrm{~A}$ & Male bathroom & 28 & 224 & & 100 & & -100 & & 26.8 & \\
\hline 14 & $203 B$ & Male bathroom & 26 & 208 & & 100 & & -100 & & 28.8 & \\
\hline 16 & 201 & Holding & 86 & 688 & 100 & & & 100 & 67 & 8.7 & $(5.8)$ \\
\hline 17 & 301 & Linac \#1 & 532 & 5852 & 680 & 820 & & -140 & 456 & 8.4 & (4.7) \\
\hline 18 & & Control & 254 & 2540 & 350 & & & 350 & 235 & 8.3 & (5.6) \\
\hline 19 & 303 & Linac \#2 & 532 & 5852 & 680 & 820 & & -140 & 456 & 8.4 & (4.7) \\
\hline 21 & 205 & Fem. changing $\mathrm{rm}$ & 117 & 936 & 200 & & & 200 & 134 & 12.8 & (8.6) \\
\hline 21 & $205 B$ & Female bathroom & 26 & 208 & & 100 & & -100 & & 28.8 & \\
\hline 21 & $205 A$ & Female bathroom & 28 & 224 & & 100 & & -100 & & 26.8 & \\
\hline 24 & & Waiting area & 840 & 10080 & 440 & & & 440 & 295 & 2.6 & (1.8) \\
\hline 25 & & Stairwell \#5 & 180 & 7200 & & & & & & & \\
\hline 26 & 401 & Storage & 325 & 6500 & & & & & & & \\
\hline 27 & $401 \mathrm{~A}$ & Internal comm. & 100 & 800 & & & & & & & \\
\hline 66 & $301 \mathrm{~A}$ & Storage & 10 & 100 & & & & & & & \\
\hline 67 & $303 \mathrm{~A}$ & Storage & 10 & 100 & & & & & & & \\
\hline
\end{tabular}


Table 1.1c Treatment Area (Zone \#1c) Ventilation Specifications

\begin{tabular}{|c|c|c|c|c|c|c|c|c|c|c|}
\hline \multirow[b]{2}{*}{ Space \# } & \multirow[b]{2}{*}{ Room \# } & \multirow[b]{2}{*}{ Description } & \multirow[b]{2}{*}{$\begin{array}{c}\text { Floor Area } \\
\left(\mathrm{ft}^{\wedge} 2\right)\end{array}$} & \multirow[b]{2}{*}{$\begin{array}{l}\text { Volume } \\
\left(f^{\wedge} 3\right)\end{array}$} & \multicolumn{5}{|c|}{ Design Airflow Rate $(\mathrm{cfm})$} & \multirow{2}{*}{$\begin{array}{c}\text { Design Air } \\
\text { Exchange } \\
\text { Rate } \\
(1 / \mathrm{hr}) \\
\end{array}$} \\
\hline & & & & & Supply & Exhaust & Return & Net & $\begin{array}{l}\text { Minimum } \\
\text { Outdoor } \\
\text { Air Intake }\end{array}$ & \\
\hline 15 & & Corridor D & 212 & 2120 & & & 470 & -470 & & 13.3 \\
\hline 22 & 208 & Clean linen & 35 & 280 & 70 & 60 & & 10 & 47 & 15.0 \\
\hline 23 & $204 \mathrm{~A}$ & Residents & 87 & 696 & 110 & & 120 & -10 & & 10.3 \\
\hline 34 & 200 & Nurses station & 62 & 496 & 100 & & & 100 & 67 & 12.1 \\
\hline 35 & 402 & Janitor's closet & 28 & 224 & & 50 & & -50 & & 13.4 \\
\hline 36 & 210 & Dirty linen & 27 & 216 & 50 & 60 & & -10 & 34 & 16.7 \\
\hline 38 & $406 \mathrm{~F}$ & Office & 113 & 904 & 110 & & 110 & & & 7.3 \\
\hline 39 & 406E & Office & 96 & 768 & 110 & & 110 & & 74 & 8.6 \\
\hline 40 & $406 D$ & Office & 96 & 768 & 110 & & 110 & & 74 & 8.6 \\
\hline 41 & $204 \mathrm{C}$ & Exam room $A$ & 102 & 816 & 130 & & 130 & & 87 & 9.6 \\
\hline 42 & 204B & Exam room $B$ & 102 & 816 & 130 & T & 130 & & 87 & 9.6 \\
\hline 43 & $101 \mathrm{~B}$ & Exam room $\mathrm{C}$ & 102 & 816 & 130 & & 130 & & 87 & 9.6 \\
\hline 44 & $101 \mathrm{~A}$ & Exam room D & 102 & 816 & 130 & & 130 & & 87 & 9.6 \\
\hline 45 & $101 \mathrm{C}$ & Planning & 132 & 1056 & 115 & & 110 & 5 & 77 & 6.5 \\
\hline 47 & $406 \mathrm{C}$ & Office & 107 & 856 & 110 & & 110 & & 74 & 7.7 \\
\hline 48 & $406 \mathrm{~B}$ & Office & 118 & 944 & 110 & & 110 & & 74 & 7.0 \\
\hline 49 & $406 \mathrm{~A}$ & Office & 93 & 744 & 110 & & 110 & & 74 & 8.9 \\
\hline 70 & & Secretarial Space & 605 & 4840 & 460 & & 460 & & 308 & 5.7 \\
\hline
\end{tabular}

Table 1.1d Treatment Area (Zone \#1d) Ventilation Specifications

\begin{tabular}{|c|c|c|c|c|c|c|c|c|c|c|}
\hline \multirow[b]{2}{*}{ Space \# } & \multirow[b]{2}{*}{ Room \# } & \multirow[b]{2}{*}{ Description } & \multirow[b]{2}{*}{$\begin{array}{c}\text { Floor Area } \\
\left(\mathrm{ft}^{\wedge} 2\right)\end{array}$} & \multirow[b]{2}{*}{$\begin{array}{l}\text { Volume } \\
\left(\mathrm{ft}^{\wedge} 3\right)\end{array}$} & \multicolumn{5}{|c|}{ Design Airflow Rate $(\mathrm{cfm})$} & \multirow{2}{*}{$\begin{array}{c}\text { Design Air } \\
\text { Exchange } \\
\text { Rate } \\
(1 / \mathrm{hr})\end{array}$} \\
\hline & & & & & Supply & Exhaust & Return & Net & $\begin{array}{l}\text { Minimum } \\
\text { Outdoor } \\
\text { Air Intake }\end{array}$ & \\
\hline 50 & 100 & Consultant office & 103 & 824 & 110 & & 110 & & & 8.0 \\
\hline 51 & $102 \mathrm{C}$ & Physicist office & 110 & 880 & 110 & & 110 & & 74 & 7.5 \\
\hline 52 & $102 B$ & Physics Lab & 148 & 1184 & 210 & 210 & & & & 10.6 \\
\hline 53 & 104 & Computer room & 153 & 1224 & 135 & & 135 & & 90 & 6.6 \\
\hline 54 & $413 \mathrm{~A}$ & Patient bathroom & 30 & 240 & & 100 & & -100 & & 25.0 \\
\hline 55 & 412 & Janitor closet & 28 & 224 & 50 & 75 & & -25 & 34 & 20.1 \\
\hline 56 & 409 & Film room & 97 & 776 & 120 & 280 & & -160 & & 21.6 \\
\hline 57 & $413 B$ & Simulator Control & 56 & 560 & 260 & & 680 & -420 & 174 & 72.9 \\
\hline 58 & 413 & Simulator & 530 & 5300 & 520 & & & 520 & 348 & 5.9 \\
\hline 59 & $106 \mathrm{~A}$ & Storage room & 17 & 136 & & & & & & \\
\hline 60 & 106 & Copy room & 138 & 1104 & 115 & & 135 & -20 & 77 & 7.3 \\
\hline 61 & 106B & Office & 110 & 880 & 135 & & 135 & & 90 & 9.2 \\
\hline 62 & 411 & Dark room & 15 & 120 & & 140 & & -140 & & 70.0 \\
\hline 71 & $102 A$ & Computer room & 188 & 1880 & 100 & & 100 & & 67 & 3.2 \\
\hline 73 & & Corridor $F$ & 416 & 4160 & 330 & & & 330 & 221 & 4.8 \\
\hline
\end{tabular}


Table 1.1e Treatment Area (Zone \#1e) Ventilation Specifications

\begin{tabular}{|c|c|c|c|c|c|c|c|c|c|c|}
\hline \multirow[b]{2}{*}{ Space \# } & \multirow[b]{2}{*}{ Room \# } & \multirow[b]{2}{*}{ Description } & \multirow[b]{2}{*}{$\begin{array}{c}\text { Floor Area } \\
\left(\mathrm{ft}^{\wedge} 2\right)\end{array}$} & \multirow[b]{2}{*}{$\begin{array}{l}\text { Volume } \\
\left(\mathrm{ft}^{\wedge} 3\right)\end{array}$} & \multicolumn{5}{|c|}{ Design Airflow Rate (cfm) } & \multirow{2}{*}{$\begin{array}{c}\text { Design Air } \\
\text { Exchange } \\
\text { Rate } \\
(1 / \mathrm{hr})\end{array}$} \\
\hline & & & & & Supply & Exhaust & Retum & Net & \begin{tabular}{|c|} 
Minimum \\
Outdoor \\
Air Intake \\
\end{tabular} & \\
\hline 20 & & Corridor E & 440 & 4400 & 500 & & & 500 & & 6.8 \\
\hline 28 & 403 & Linac \#3 & 600 & 6600 & 1100 & 1320 & & -220 & 737 & 12.0 \\
\hline 29 & $405 \mathrm{~A}$ & Upper Hall & 44 & 352 & 780 & 900 & & -120 & & 153.4 \\
\hline 30 & 405 & Hall & 161 & 1610 & 325 & 780 & & -455 & 218 & 29.1 \\
\hline 30 & $405 E$ & Closet & 10 & 100 & & & & & & \\
\hline 31 & & Control & 424 & 4240 & 700 & & & 700 & 469 & 9.9 \\
\hline 32 & $407 B$ & Cylclotron & 297 & 3267 & 780 & 900 & & -120 & & 16.5 \\
\hline 33 & 407 & Linac \#4 & 598 & 5980 & 1100 & 1320 & & -220 & 737 & 13.2 \\
\hline 37 & 405D1 & Closet & 14 & 140 & & & & & & \\
\hline 37 & $405 C 4 D$ & Equipment Storage & 78 & 780 & & & & & & \\
\hline 46 & $405 C 2$ & Bathroom & 34 & 272 & & & & & & \\
\hline 63 & $405 \mathrm{C} 1$ & Lower room & 272 & 2176 & & & & & & \\
\hline 64 & $405 C$ & Back room & 158 & 1580 & 325 & & & 325 & 218 & 12.3 \\
\hline 68 & 403A & Storage & 38 & 380 & & & & & & \\
\hline 69 & 407A & Storage & 38 & 304 & & & & & & \\
\hline 74 & & Broom Closet & 12 & 96 & & & & & & \\
\hline 75 & $405 A 3$ & Changing room & 44 & 352 & & & & & & \\
\hline 76 & $405 A 2$ & Shower & 20 & 160 & & & & & & \\
\hline 77 & $405 A 1$ & Changing room & 42 & 336 & & & & & & \\
\hline
\end{tabular}


Table 1.2 Level B3B (Zone \#2) Ventilation Specifications

\begin{tabular}{|c|c|c|c|c|c|c|c|c|c|}
\hline \multirow[b]{2}{*}{ Space \# } & \multirow[b]{2}{*}{ Room \# } & \multirow[b]{2}{*}{ Description } & \multirow[b]{2}{*}{$\begin{array}{c}\text { Floor Area } \\
\left(\mathrm{ft}^{\wedge} 2\right)\end{array}$} & \multirow[b]{2}{*}{$\begin{array}{l}\text { Volume } \\
\left(\mathrm{ft}^{\wedge} 3\right)\end{array}$} & \multicolumn{4}{|c|}{ Design Airflow Rate (cfm) } & \multirow{2}{*}{$\begin{array}{c}\text { Design Air } \\
\text { Exchange } \\
\text { Rate } \\
(1 / \mathrm{hr})\end{array}$} \\
\hline & & & & & Supply & Exhaust & $\begin{array}{l}\text { Fume } \\
\text { Hoods }\end{array}$ & Net & \\
\hline 1 & & Corridor & 717 & 5736 & & & & & \\
\hline 8 & 47 & Office & 168 & 1344 & 170 & & & 170 & 7.6 \\
\hline 9 & 47 & Office & 156 & 1248 & 175 & 400 & & -225 & 19.2 \\
\hline 10 & 48 & Secretary & 162 & 1296 & 120 & & & 120 & 5.6 \\
\hline 11 & 48 & Office & 106 & 848 & 90 & & & 90 & 6.4 \\
\hline 12 & 48 & Office & 106 & 848 & 90 & & & 90 & 6.4 \\
\hline 13 & & Corridor & 581 & 4648 & & & & & \\
\hline 14 & 44 & Cobalt 60 console & 102 & 816 & 130 & & & 130 & 9.6 \\
\hline 16 & 44 & Cobalt 60 unit & 348 & 3132 & 220 & 220 & & & 4.2 \\
\hline 17 & 36 & Work lab & 183 & 1464 & 210 & 250 & & & 8.6 \\
\hline 18 & 36 & Instruments & 70 & 560 & 70 & & & 70 & 7.5 \\
\hline 19 & 36 & Darkroom & 97 & 776 & 70 & 70 & & & 5.4 \\
\hline 20 & 36 & Glass wash & 237 & 1896 & 240 & 240 & & & 7.6 \\
\hline 21 & 34 & Office & 137 & 1096 & 110 & & & 110 & 6.0 \\
\hline 22 & 32 & Work lab & 237 & 1896 & 480 & & 750 & -270 & 23.7 \\
\hline 26 & 31 & Office & 86 & 688 & 75 & & & 75 & 6.5 \\
\hline 27 & 35 & Tissue culture & 197 & 1576 & 200 & 180 & & 20 & 7.6 \\
\hline 28 & 33 & Office & 90 & 720 & 70 & & & 70 & 5.8 \\
\hline 29 & 35 & Work Lab & 258 & 2064 & 290 & 260 & & 30 & 8.4 \\
\hline 30 & 35 & Tissue culture & 143 & 1144 & 210 & 190 & & 20 & 11.0 \\
\hline 31 & 39 & Closet & 28 & 224 & 100 & & & 100 & 26.8 \\
\hline 32 & 39 & Work Lab & 172 & 1376 & 200 & 180 & & 20 & 8.7 \\
\hline 33 & 39 & Tissue culture & 167 & 1336 & 200 & 200 & & & 9.0 \\
\hline 34 & 39 & Tissue culture & 80 & 640 & 170 & 150 & & 20 & 15.9 \\
\hline 35 & 41 & Female bathroom & 63 & 504 & & 100 & & -100 & 11.9 \\
\hline 36 & 43 & Male bathroom & 45 & 360 & & 70 & & -70 & 11.7 \\
\hline 37 & 45 & Janitor closet & 19 & 152 & & 50 & & -50 & 19.7 \\
\hline 38 & 47 & Photocopy & 80 & 640 & 105 & & & 105 & 9.8 \\
\hline 39 & 49 & Procurement & 106 & 848 & 105 & & & 105 & 7.4 \\
\hline 40 & 44 & Cobalt 60 storage & 60 & 480 & & 130 & & -130 & 16.3 \\
\hline 41 & 51 & Laboratory & 578 & 4624 & 300 & 300 & & 0 & 3.9 \\
\hline 46 & 56 & Machine Room & 516 & 4128 & 410 & 410 & & & 6.0 \\
\hline & 50 & Future Lab Space & 1900 & 15200 & & & & & \\
\hline
\end{tabular}


Table 1.3 Level B2.5B (Zone \#3) Ventilation Specifications

\begin{tabular}{|c|c|c|c|c|c|c|c|c|c|}
\hline \multirow[b]{2}{*}{ Space \# } & \multirow[b]{2}{*}{ Room \# } & \multirow[b]{2}{*}{ Description } & \multirow[b]{2}{*}{$\begin{array}{c}\text { Floor Area } \\
\left(\mathrm{ft}^{\wedge} 2\right)\end{array}$} & \multirow[b]{2}{*}{$\begin{array}{l}\text { Volume } \\
\left(\mathrm{ft}^{\wedge} 3\right)\end{array}$} & \multicolumn{4}{|c|}{ Design Airflow Rate (cfm) } & \multirow{2}{*}{$\begin{array}{c}\text { Design Air } \\
\text { Exchange } \\
\text { Rate } \\
(1 / \mathrm{hr})\end{array}$} \\
\hline & & & & & Supply & Exhaust & $\begin{array}{l}\text { Fume } \\
\text { Hoods }\end{array}$ & Net & \\
\hline 46 & & Corridor & 505 & 4040 & & & & & \\
\hline 48 & & Storage & 160 & 960 & & & & & \\
\hline 49 & 48 & Secretary & 177 & 1416 & 120 & & & 120 & 5.1 \\
\hline 50 & 48 & Office & 164 & 1312 & 120 & & & 120 & 5.5 \\
\hline 51 & & Corridor & 278 & 2224 & & & & & \\
\hline 53 & 44 & Female bathroom & 45 & 360 & & 50 & & -50 & 8.3 \\
\hline 54 & & Janitor closet & 16 & 160 & & 50 & & -50 & 18.8 \\
\hline 55 & 46 & Male bathroom & 126 & 1008 & & 120 & & -120 & 7.1 \\
\hline 56 & & Storage & 23 & 184 & & 150 & & -150 & 48.9 \\
\hline 57 & 57 & Conference room & 383 & 3447 & 50 & 500 & & & 8.7 \\
\hline 59 & & Corridor & 319 & 2552 & 30 & & & & \\
\hline 62 & 33 & Storage & 95 & 760 & 0 & & & & \\
\hline 63 & 33 & Laboratory & 199 & 1592 & 200 & 220 & 750 & -770 & 36.6 \\
\hline 64 & 33 & Laboratory & 80 & 640 & 145 & 120 & & 25 & 13.6 \\
\hline 65 & 35 & Laboratory & 65 & 520 & 600 & & 750 & -150 & 86.5 \\
\hline 66 & 35 & Laboratory & 66 & 528 & 225 & 250 & & -25 & 28.4 \\
\hline 67 & 41 & Storage & 64 & 512 & 170 & 170 & & 170 & 19.9 \\
\hline 68 & 39 & Laboratory & 130 & 1040 & 175 & 175 & & & 10.1 \\
\hline 69 & 41 & Laboratory & 132 & 1056 & 175 & & & 175 & 9.9 \\
\hline 70 & & Copy room & 24 & 216 & & & & & \\
\hline 71 & 45 & Office & 88 & 704 & 150 & & & 150 & 12.8 \\
\hline 72 & 49 & Office & 122 & 976 & 90 & & & 90 & 5.5 \\
\hline 73 & 49 & Secretary & 181 & 1448 & 130 & & & 130 & 5.4 \\
\hline 74 & 49 & Office & 105 & 840 & 85 & & & 85 & 6.1 \\
\hline 75 & 53 & Office & 118 & 944 & 85 & & & 85 & 5.4 \\
\hline 76 & 53 & Secretary & 202 & 1616 & 145 & & & 145 & 5.4 \\
\hline 77 & 53 & Office & 217 & 1736 & 120 & 120 & & & 4.1 \\
\hline
\end{tabular}


Table 1.4 Level 1B (Zone \#4) Ventilation Specifications

\begin{tabular}{|c|c|c|c|c|c|c|c|c|c|}
\hline \multirow[b]{2}{*}{ Space \# } & \multirow[b]{2}{*}{ Room \# } & \multirow[b]{2}{*}{ Description } & \multirow[b]{2}{*}{$\begin{array}{c}\text { Floor Area } \\
\left(f t^{\wedge} 2\right)\end{array}$} & \multirow[b]{2}{*}{$\begin{array}{c}\text { Volume } \\
\left(\mathrm{f}^{\wedge} \wedge\right)\end{array}$} & \multicolumn{4}{|c|}{ Design Airflow Rate (cfm) } & \multirow{2}{*}{$\begin{array}{c}\text { Design Air } \\
\text { Exchange } \\
\text { Rate } \\
(1 / \mathrm{hr})\end{array}$} \\
\hline & & & & & Supply & Exhaust & $\begin{array}{l}\text { Fume } \\
\text { Hoods }\end{array}$ & Net & \\
\hline$\overline{1}$ & $53 \mathrm{C}$ & Office & 90 & 720 & 145 & 145 & & & 12.1 \\
\hline 2 & 538 & Office & 97 & 776 & 165 & 165 & & & 12.8 \\
\hline 3 & $51 B$ & Office & 127 & 1016 & 200 & 200 & & & 11.8 \\
\hline 4 & $53 \mathrm{~A}$ & Office & 105 & 840 & 125 & 125 & & & 8.9 \\
\hline 5 & $51 C$ & Office & 138 & 1104 & 125 & 125 & & & 6.8 \\
\hline 6 & $51 A$ & Office & 144 & 1152 & 225 & 225 & & & 11.7 \\
\hline 7 & $47 C$ & Office & 127 & 1016 & 200 & 200 & & & 11.8 \\
\hline 8 & $47 \mathrm{~B}$ & Office & 129 & 1032 & 200 & 200 & & & 11.6 \\
\hline 9 & $47 D$ & Office & 108 & 864 & 125 & 125 & & & 8.7 \\
\hline 10 & $47 A$ & Office & 84 & 672 & 125 & 125 & & & 11.2 \\
\hline 11 & 45 & Laboratory & 215 & 1720 & 350 & 150 & & 200 & 12.2 \\
\hline 12 & $43 A$ & Closet & 28 & 224 & & & & & \\
\hline 13 & 43 & Laboratory & 218 & 1744 & 250 & 550 & & -300 & 18.9 \\
\hline 14 & $41 B$ & Janitor & 56 & 448 & & 50 & & -50 & 6.7 \\
\hline 15 & $41 C$ & Male bathroom & 75 & 600 & 100 & 200 & & -100 & 20.0 \\
\hline 16 & $41 \mathrm{~A}$ & Female bathroom & 65 & 520 & & 150 & & -150 & 17.3 \\
\hline 17 & $37 A$ & Office & 150 & 1200 & 250 & 250 & & & 12.5 \\
\hline 18 & $37 B$ & Office & 116 & 928 & 125 & 125 & & & 8.1 \\
\hline 19 & 35 & Storage & 220 & 1760 & 250 & 250 & & & 8.5 \\
\hline 20 & 58 & Laboratory & 424 & 3392 & 550 & & 600 & -50 & 10.6 \\
\hline 21 & 54 & Laboratory & 228 & 1824 & 525 & 575 & & -50 & 18.9 \\
\hline 22 & 52 & Mould Lab & 113 & 904 & 125 & 175 & & -50 & 11.6 \\
\hline 23 & $46 / 50$ & Entry way & 248 & 1984 & 225 & & & 225 & 6.8 \\
\hline 25 & $46 \mathrm{~A}$ & Radiation Lab & 175 & 1400 & 235 & & 815 & -580 & 34.9 \\
\hline 26 & $46 B$ & Laboratory & 89 & 712 & 125 & & & 125 & 10.5 \\
\hline 27 & $50 A$ & Laboratory & 175 & 1400 & 250 & & 750 & -500 & 32.1 \\
\hline 28 & 44 & Cylinder Storage & 70 & 560 & & 100 & & -100 & 10.7 \\
\hline $\begin{array}{l}29 \\
30\end{array}$ & $42 A$ & $\begin{array}{l}\text { Laboratory } \\
\text { Hall }\end{array}$ & $\begin{array}{r}120 \\
33\end{array}$ & $\begin{array}{l}960 \\
264\end{array}$ & 100 & 150 & & -50 & 9.4 \\
\hline 31 & $44 A$ & Laboratory & 145 & 1160 & 225 & 225 & & & 11.6 \\
\hline 32 & $40 A$ & Laboratory & 80 & 640 & 150 & 150 & & & 14.1 \\
\hline 33 & 40 & Lab - Animal cages & 320 & 2560 & 395 & 470 & & -75 & 11.0 \\
\hline 34 & $38 \mathrm{~A}$ & Lab - Animal cages & 80 & 640 & 75 & 100 & & -25 & 9.4 \\
\hline 35 & 34 & Lab & 160 & 1280 & & & & & \\
\hline 36 & $34 A$ & Lab & 152 & 1216 & 50 & 100 & & -50 & 4.9 \\
\hline 37 & $34 B$ & Lab & 65 & 520 & 50 & & & 50 & 5.8 \\
\hline $\begin{array}{l}38 \\
39 \\
\end{array}$ & $36 \mathrm{C}$ & $\begin{array}{l}\text { Lab } \\
\text { Corridor }\end{array}$ & $\begin{array}{l}110 \\
905 \\
\end{array}$ & $\begin{array}{r}880 \\
7240 \\
\end{array}$ & 100 & 150 & & -50 & 10.2 \\
\hline
\end{tabular}


Table 1.5 Modified Level B3B (Zone\#2) Ventilation Specifications

\begin{tabular}{|c|c|c|c|c|c|c|c|c|c|}
\hline \multirow[b]{2}{*}{ Space \# } & \multirow[b]{2}{*}{ Room \# } & \multirow[b]{2}{*}{ Description } & \multirow[b]{2}{*}{$\begin{array}{c}\text { Floor Area } \\
\left(\left(t^{\wedge} 2\right)\right.\end{array}$} & \multirow[b]{2}{*}{$\begin{array}{c}\text { Volume } \\
\left(\mathrm{ft}^{\wedge} 3\right)\end{array}$} & \multicolumn{4}{|c|}{ Design Airflow Rate (cim) } & \multirow{2}{*}{$\begin{array}{c}\text { Design Air } \\
\text { Exchange } \\
\text { Rate } \\
(1 / \mathrm{hr}) \\
\end{array}$} \\
\hline & & & & & Supply & Exhaust & $\begin{array}{l}\text { Fume } \\
\text { Hoods }\end{array}$ & Net & \\
\hline$\overline{1}$ & & Corridor & 717 & 5736 & & & & & \\
\hline 8 & 47 & Office & 168 & 1344 & 247 & & & 247 & 11.0 \\
\hline 9 & 47 & Office & 156 & 1248 & 254 & 400 & & -146 & 19.2 \\
\hline 10 & 48 & Secretary & 162 & 1296 & 174 & & & 174 & 8.1 \\
\hline 11 & 48 & Office & 106 & 848 & 131 & & & 131 & 9.3 \\
\hline 12 & 48 & Office & 106 & 848 & 131 & & & 131 & 9.3 \\
\hline 13 & & Corridor & 581 & 4648 & & & & & \\
\hline 14 & 44 & Cobalt 60 console & 102 & 816 & 189 & & & 189 & 13.9 \\
\hline 16 & 44 & Cobalt 60 unit & 348 & 3132 & 320 & 220 & & 100 & 6.1 \\
\hline 17 & 36 & Work lab & 183 & 1464 & 305 & 210 & & 95 & 12.5 \\
\hline 18 & 36 & Instruments & 70 & 560 & 102 & & & 102 & 10.9 \\
\hline 19 & 36 & Darkroom & 97 & 776 & 102 & 70 & & 32 & 7.9 \\
\hline 20 & 36 & Glass wash & 237 & 1896 & 349 & 240 & & 109 & 11.0 \\
\hline 21 & 34 & Office & 137 & 1096 & 160 & & & 160 & 8.8 \\
\hline 22 & 32 & Work lab & 237 & 1896 & 697 & & 750 & -53 & 23.7 \\
\hline 26 & 31 & Office & 86 & 688 & 109 & & & 109 & 9.5 \\
\hline 27 & 35 & Tissue culture & 197 & 1576 & 291 & 180 & & 111 & 11.1 \\
\hline 28 & 33 & Office & 90 & 720 & 102 & & & 102 & 8.5 \\
\hline 29 & 35 & Work Lab & 258 & 2064 & 421 & 260 & & 161 & 12.3 \\
\hline 30 & 35 & Tissue culture & 143 & 1144 & 305 & 190 & & 115 & 16.0 \\
\hline 31 & 39 & Closet & 28 & 224 & 145 & & & 145 & 38.9 \\
\hline 32 & 39 & Work Lab & 172 & 1376 & 291 & 180 & & 111 & 12.7 \\
\hline 33 & 39 & Tissue culture & 167 & 1336 & 291 & 200 & & 91 & 13.1 \\
\hline 34 & 39 & Tissue culture & 80 & 640 & 247 & 150 & & 97 & 23.2 \\
\hline 35 & 41 & Female bathroom & 63 & 504 & & 100 & & -100 & 11.9 \\
\hline 36 & 43 & Male bathroom & 45 & 360 & & 70 & & -70 & 11.7 \\
\hline 37 & 45 & Janitor closet & 19 & 152 & & 50 & & -50 & 19.7 \\
\hline 38 & 47 & Photocopy & 80 & 640 & 153 & & & 153 & 14.3 \\
\hline 39 & 49 & Procurement & 106 & 848 & 153 & & & 153 & 10.8 \\
\hline 40 & 44 & Cobalt 60 storage & 60 & 480 & & 130 & & -130 & 16.3 \\
\hline 41 & 51 & Laboratory & 512 & 4096 & 436 & 200 & & 236 & 6.4 \\
\hline 44 & 55 & Storage & 66 & 528 & & 100 & & -100 & 11.4 \\
\hline 46 & $\begin{array}{l}56 \\
50 \\
\end{array}$ & $\begin{array}{l}\text { Machine Room } \\
\text { Future Lab Space }\end{array}$ & $\begin{array}{r}516 \\
1900 \\
\end{array}$ & $\begin{array}{r}4128 \\
15200 \\
\end{array}$ & 596 & 410 & & 186 & 8.7 \\
\hline
\end{tabular}


Table 1.6 Modified Level B2.5B (Zone \#3) Ventilation Specifications

\begin{tabular}{|c|c|c|c|c|c|c|c|c|c|}
\hline \multirow[b]{2}{*}{ Space \# } & \multirow[b]{2}{*}{ Room \# } & \multirow[b]{2}{*}{ Description } & \multirow[b]{2}{*}{$\begin{array}{c}\text { Floor Area } \\
\left(f \mathrm{ft}^{\wedge} 2\right)\end{array}$} & \multirow[b]{2}{*}{$\begin{array}{l}\text { Volume } \\
\left(\mathrm{ft}^{\wedge} 3\right)\end{array}$} & \multicolumn{4}{|c|}{ Design Airflow Rate (cfm) } & \multirow{2}{*}{$\begin{array}{c}\text { Design Air } \\
\text { Exchange } \\
\text { Rate } \\
(1 / \mathrm{hr})\end{array}$} \\
\hline & & & & & Supply & Exhaust & $\begin{array}{l}\text { Fume } \\
\text { Hoods }\end{array}$ & Net & \\
\hline $\begin{array}{l}46 \\
48\end{array}$ & & $\begin{array}{l}\text { Corridor } \\
\text { Storage }\end{array}$ & 505 & $\begin{array}{r}4040 \\
960\end{array}$ & & & & & \\
\hline $\begin{array}{l}48 \\
49\end{array}$ & 48 & $\begin{array}{l}\text { Storage } \\
\text { Secretary }\end{array}$ & $\begin{array}{l}160 \\
177\end{array}$ & $\begin{array}{r}960 \\
1416\end{array}$ & 174 & & & 174 & 7.4 \\
\hline 50 & 48 & Office & 164 & 1312 & 174 & & & 174 & 8.0 \\
\hline 51 & & Corridor & 278 & 2224 & & & & & \\
\hline 53 & 44 & Female bathroom & 45 & 360 & & 50 & & -50 & 8.3 \\
\hline 54 & & Janitor closet & 16 & 160 & & 50 & & -50 & 18.8 \\
\hline 55 & 46 & Male bathroom & 126 & 1008 & & 120 & & -120 & 7.1 \\
\hline 56 & & Storage & 23 & 184 & & 150 & & -150 & 48.9 \\
\hline 57 & 38 & Conference room & 383 & 3447 & 727 & 500 & & 227 & 12.6 \\
\hline 59 & & Corridor & 319 & 2552 & & & & & \\
\hline 62 & 33 & Storage & 95 & 760 & & & & & \\
\hline 63 & 33 & Laboratory & 199 & 1592 & 291 & 220 & 750 & -679 & 36.6 \\
\hline 64 & 33 & Laboratory & 80 & 640 & 211 & 120 & & 91 & 19.8 \\
\hline 65 & 35 & Laboratory & 65 & 520 & 872 & & 750 & 122 & 100.6 \\
\hline 66 & 35 & Laboratory & 66 & 528 & 327 & 250 & & 77 & 37.2 \\
\hline 67 & 41 & Storage & 64 & 512 & 247 & & & 247 & 28.9 \\
\hline 68 & 39 & Laboratory & 130 & 1040 & 254 & 175 & & 79 & 14.7 \\
\hline 69 & 41 & Laboratory & 132 & 1056 & 254 & & & 254 & 14.4 \\
\hline 70 & & Copy room & 24 & 216 & & & & & \\
\hline 71 & 45 & Office & 88 & 704 & 218 & & & 218 & 18.6 \\
\hline 72 & 49 & Office & 122 & 976 & 131 & & & 131 & 8.0 \\
\hline 73 & 49 & Secretary & 181 & 1448 & 189 & & & 189 & 7.8 \\
\hline 74 & 49 & Office & 105 & 840 & 124 & & & 124 & 8.8 \\
\hline 75 & 53 & Office & 118 & 944 & 124 & & & 124 & 7.9 \\
\hline 76 & 53 & Secretary & 202 & 1616 & 211 & & & 211 & 7.8 \\
\hline 77 & 53 & Office & 217 & 1736 & 174 & 120 & & 54 & 6.0 \\
\hline
\end{tabular}


TREATMENT AREA

\begin{tabular}{|l|c|c|c|c|c|c|c|c|}
\hline & \multirow{2}{*}{$\begin{array}{c}\text { Floor Area } \\
\left(\mathrm{ft} \mathrm{t}^{\wedge} 2\right)\end{array}$} & \multirow{2}{*}{$\begin{array}{c}\text { Volume } \\
(\mathrm{ft} \wedge)\end{array}$} & Supply & Exhaust & Return & Net & $\begin{array}{c}\text { Minimum } \\
\text { Outdoor } \\
\text { Air Intake }\end{array}$ & $\begin{array}{c}\text { Design Air } \\
\text { Exchange } \\
\text { Rate } \\
(1 / \mathrm{hr})\end{array}$ \\
\hline Totals & 14,097 & 179,599 & 13,980 & 9,175 & 4,030 & 775 & 9,367 & 4.7 \\
\hline Fan specifications & - & & 14,000 & 9,300 & 4,400 & 300 & 9,380 & 4.7 \\
\hline
\end{tabular}

LEVELS B3B \& B2.5B

\begin{tabular}{|c|c|c|c|c|c|c|c|}
\hline \multirow[b]{2}{*}{ t } & \multirow[b]{2}{*}{$\begin{array}{l}\text { Floor Area } \\
\qquad\left(\mathrm{ft}^{\wedge} 2\right)\end{array}$} & \multirow[b]{2}{*}{$\begin{array}{c}\text { Volume } \\
\left(\mathrm{ft}^{\wedge} 3\right)\end{array}$} & \multicolumn{4}{|c|}{ Flow $(\mathrm{cfm})$} & \multirow{2}{*}{$\begin{array}{c}\text { Design Air } \\
\text { Exchange } \\
\text { Rate } \\
(1 / \mathrm{hr})\end{array}$} \\
\hline & & & Supply & Exhaust & $\begin{array}{l}\text { Fume } \\
\text { Hoods }\end{array}$ & Net & \\
\hline $\begin{array}{l}\text { Zone } 2 \text { - Level B3B } \\
\text { Zone } 3 \text { - Level B2.5B }\end{array}$ & $\begin{array}{l}7,995 \\
4,084\end{array}$ & $\begin{array}{l}64,308 \\
32.791\end{array}$ & $\begin{array}{l}4,610 \\
3,235\end{array}$ & $\begin{array}{l}3,400 \\
1,925\end{array}$ & $\begin{array}{c}750 \\
1,500\end{array}$ & $\begin{array}{l}500 \\
-20\end{array}$ & $\begin{array}{l}4.3 \\
6.0\end{array}$ \\
\hline Totals & 12,079 & 97,099 & 7,845 & 5,325 & 2,250 & 480 & 4.8 \\
\hline Fan specifications & - & - & 7,570 & 5,105 & 2,250 & 215 & 4.7 \\
\hline
\end{tabular}

\section{MODIFIED LEVELS B3B \& B2.5B}

\begin{tabular}{|l|c|c|c|c|c|c|c|}
\hline & \multirow{2}{*}{$\begin{array}{c}\text { Floor Area } \\
\left(\mathrm{ft}^{\wedge} 2\right)\end{array}$} & \multirow{2}{*}{$\begin{array}{c}\text { Volume } \\
\left(\mathrm{ft}^{\wedge} 3\right)\end{array}$} & Supply & Exhaust & $\begin{array}{c}\text { Fume } \\
\text { Hoods }\end{array}$ & Net & $\begin{array}{c}\text { Exchange } \\
\text { Rate } \\
(1 / \mathrm{hr})\end{array}$ \\
\hline Zone 2-Level B3B & 7,995 & 64,308 & 6,698 & 3,400 & 750 \\
1,500 & $\begin{array}{c}2,588 \\
1,445\end{array}$ & $\begin{array}{c}4.3 \\
6.0\end{array}$ \\
\hline Zone 3-Level B2.5B & 4,084 & 32,791 & 4,700 & 1,925 & 1,500 & 7.0 \\
\hline Totals & 12,079 & 97,099 & 11,398 & 5,325 & 2,250 & 4,033 & 7,8 \\
\hline
\end{tabular}

LEVEL 18

\begin{tabular}{|l|c|c|c|c|c|c|c|}
\hline & \multirow{2}{*}{$\begin{array}{c}\text { Floor Area } \\
\left(\mathrm{ft}^{\wedge} 2\right)\end{array}$} & $\begin{array}{c}\text { Volume } \\
\left(\mathrm{ft}^{\wedge} 3\right)\end{array}$ & Supply & Exhaust & $\begin{array}{c}\text { Fume } \\
\text { Hoods }\end{array}$ & Net & $\begin{array}{c}\text { Exchange } \\
\text { Rate } \\
(1 / \mathrm{hr})\end{array}$ \\
\hline Totals & 5,984 & 47,872 & 6,140 & 5,555 & 2,165 & $-1,580$ & 9.7 \\
\hline Fan Specifications & \multicolumn{7}{|c|}{ INFORMATION NOT AVAILABLE } \\
\hline
\end{tabular}


Table 1.8 B Corridor Ventilation Specifications

\begin{tabular}{|c|c|c|c|c|c|c|c|c|c|}
\hline FLOOR FAN & $\begin{array}{l}\text { Supply } \\
\# 18 \\
\end{array}$ & $\begin{array}{l}\text { Supply } \\
\# 19 \\
\end{array}$ & $\begin{array}{r}\text { Supply } \\
\# 20-1 / 2 \\
\end{array}$ & $\begin{array}{l}\text { TOTAL } \\
\text { SUPPLY } \\
\end{array}$ & $\begin{array}{c}\text { Exhaust } \\
\# 39\end{array}$ & $\begin{array}{c}\text { Exhaust } \\
\# 40\end{array}$ & $\begin{array}{c}\text { Exhaust } \\
\# 41 \\
\end{array}$ & $\begin{array}{l}\text { TOTAL } \\
\text { EXHAUST }\end{array}$ & $\begin{array}{l}\text { NET } \\
\text { FLOW }\end{array}$ \\
\hline 5 th & 950 & 1,100 & 19,800 & 21,850 & 1,050 & 1,200 & & 2,250 & 19,600 \\
\hline 4 th & 2,625 & 4,950 & & 7,575 & & 6,325 & 1,500 & 7,825 & -250 \\
\hline $3 r d$ & 1,275 & 2,100 & & 3,375 & 4,200 & 800 & 1,500 & 6,500 & $-3,125$ \\
\hline 2nd & 1,275 & 2,100 & & 3,375 & 4,200 & 800 & 1,500 & 6,500 & $-3,125$ \\
\hline $1 \mathrm{st}$ & 3,100 & 3,250 & & 6,350 & 5,375 & 250 & 3,000 & 8,625 & $-2,275$ \\
\hline B1 & 2,100 & 3,650 & & 5,750 & 5,375 & & 1,000 & 6,375 & -625 \\
\hline B2 & 1,800 & 4,700 & & 6,500 & 8,200 & & & 8,200 & $-1,700$ \\
\hline B3 & 10,500 & & & 10,500 & 8,750 & & & 8,750 & 1,750 \\
\hline TOTAL & 23,625 & 21,850 & 19,800 & 65,275 & 37,150 & 9,375 & 8,500 & 55,025 & 10,250 \\
\hline $\begin{array}{c}\text { Balance Report } \\
9 / 86 \\
\end{array}$ & 23,223 & - & - & & & & & & \\
\hline $\begin{array}{c}\text { Balance Report } \\
4 / 87 \\
\end{array}$ & $\cdots$ & 30,420 & -- & & & & & & \\
\hline \multicolumn{4}{|c|}{$\begin{array}{l}\text { From Partial Low Pressure Air Handling Unit Schedule } \\
\text { (date unknown) }\end{array}$} & & & & & & \\
\hline Revised & 24,800 & 30,420 & 18,540 & & & & & & \\
\hline
\end{tabular}

All airflow rates in cfm 


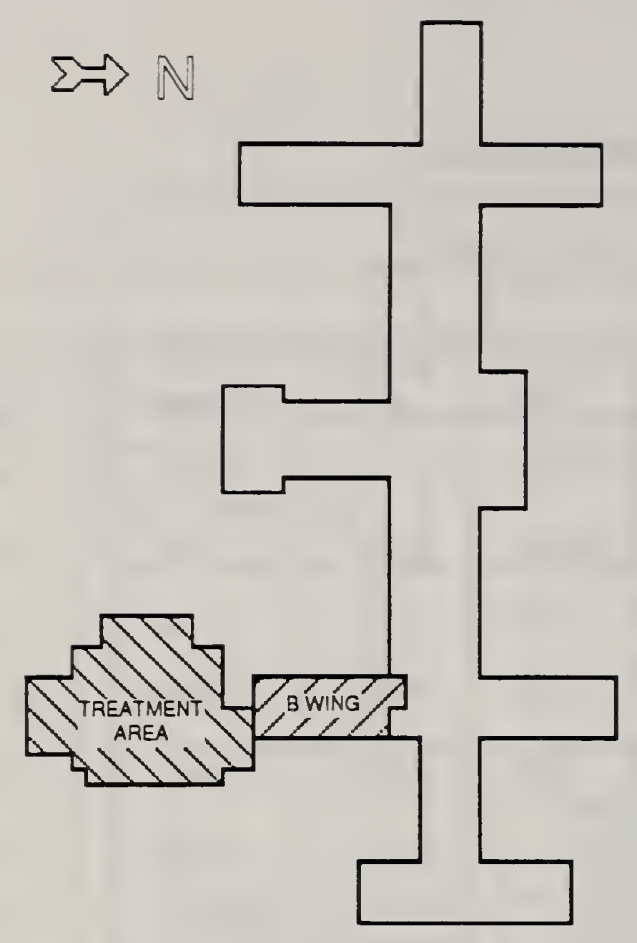

B CORRIDOR OF BUILDING 10

BUILDING 10

(from above)

(elevation)

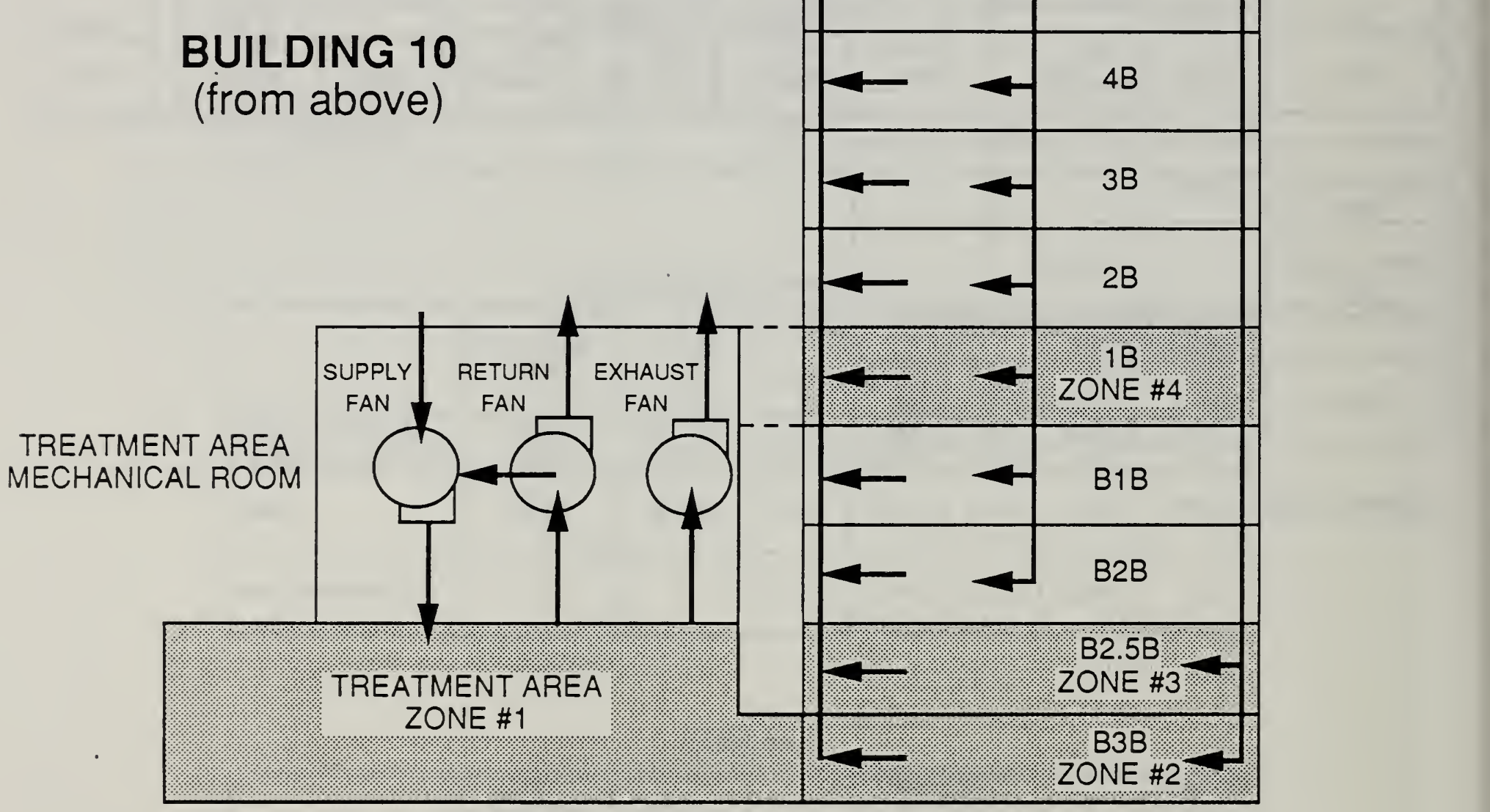

RADIATION ONCOLOGY BRANCH

Figure 1.1 Schematic of B Corridor and ROB in Building 10 


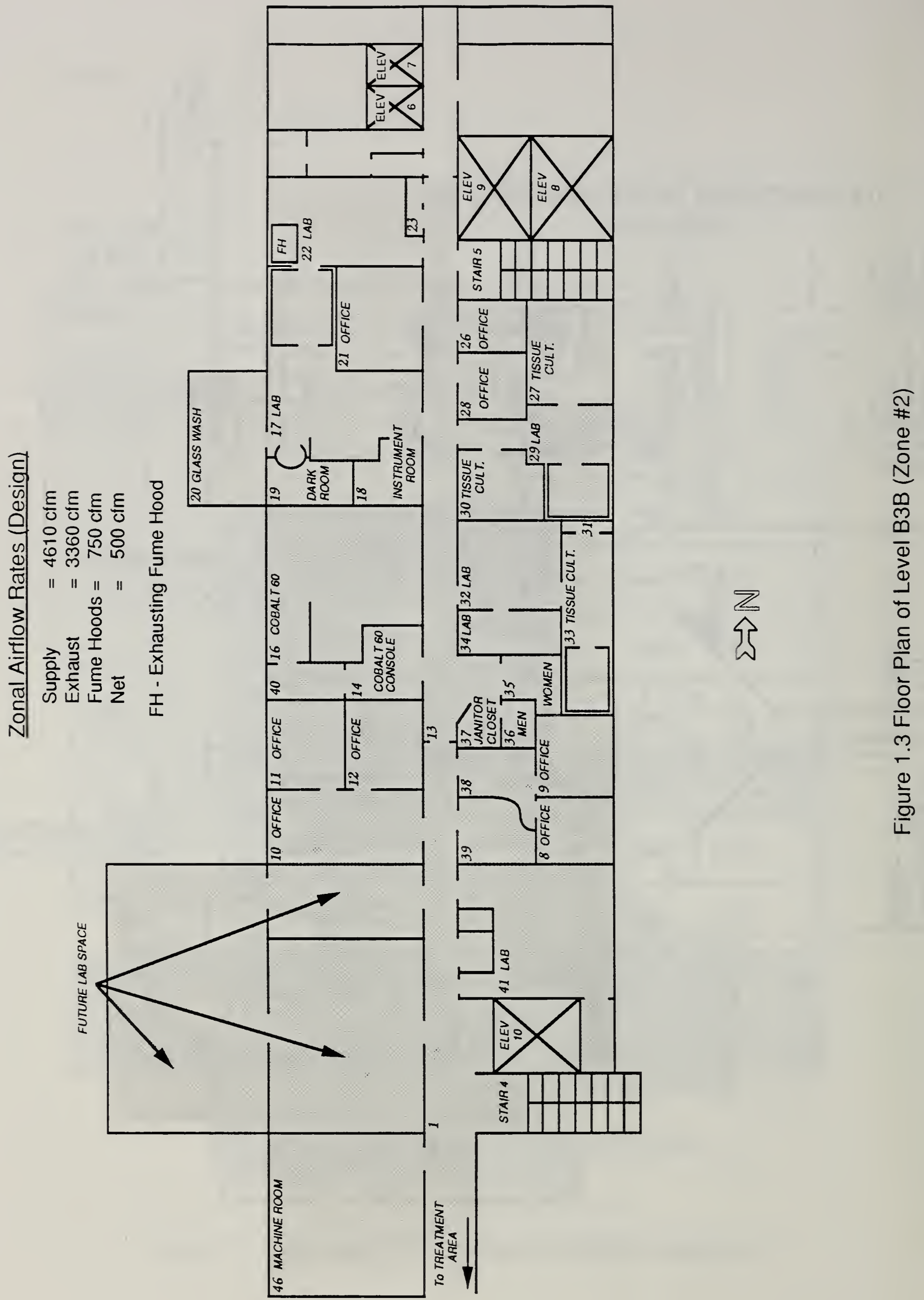



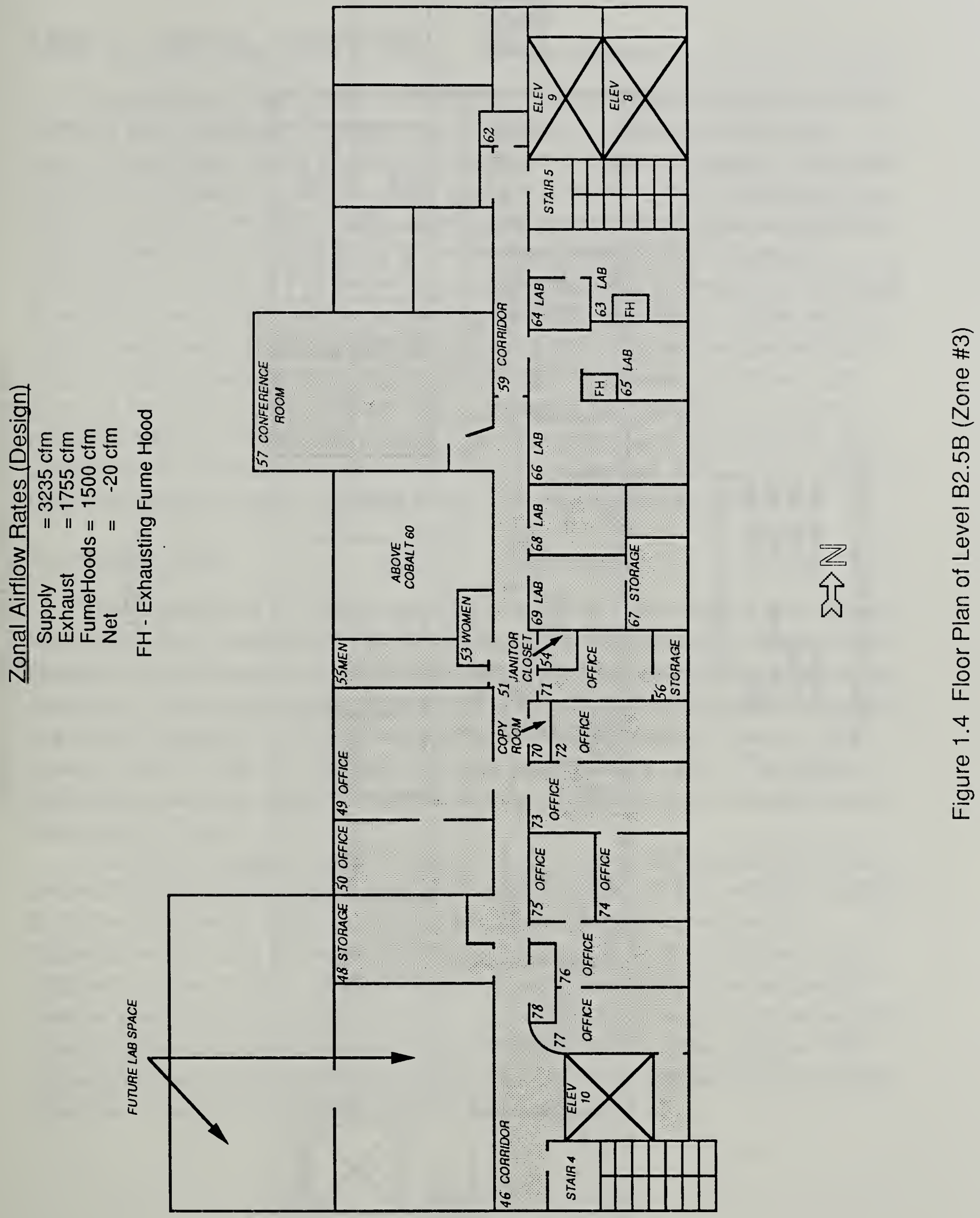


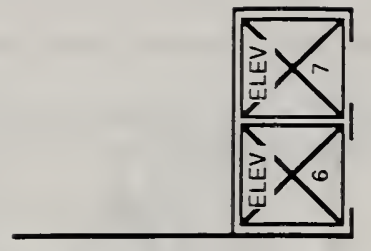

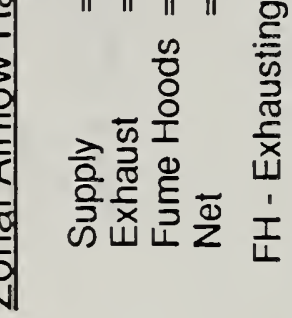
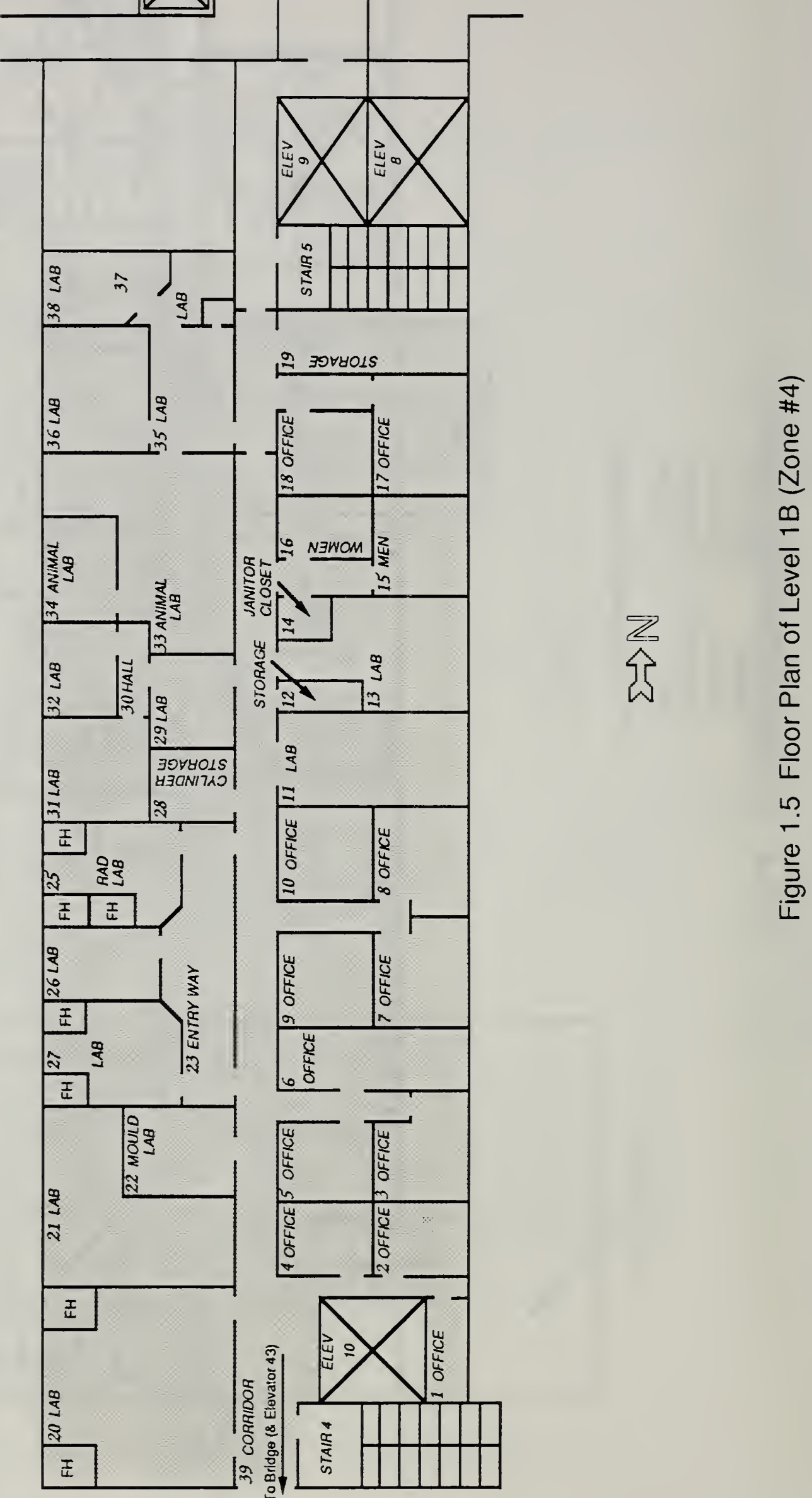


\section{TASK 2: ON-SITE INSPECTION}

The purpose of Task 2 was to inspect the ROB ventilation systems in order to compare their installation to design and to determine if certain events have occurred that might lead to a system that does not function as intended. This effort involved an inspection of the occupied space and the suspended ceiling plenum space throughout the ROB in order to compare the location and type of air diffuser and register in each room with the information contained in the mechanical drawings, to compare the ductwork layout with that shown in these same drawings, to evaluate the condition of the ductwork contained in the plenum space, and to look for water leaks or damage due to previous leaks. This section presents the results of this inspection, conducted during the first two weeks of October 1988. Some of the deficiencies identified in this inspection have since been corrected and are noted as such below. Several important issues were identified that are specific to the Treatment Area and these are discussed first, followed by a room-byroom description of other significant findings for the entire ROB facility.

\section{Treatment Area}

The inspection of the Treatment Area revealed two features that are unique to this space. First, it was found that the actual layout of the ductwork, diffusers and registers in the Linac \#4 area was very different from the layout in the mechanical drawings. The actual ductwork layout for this area, based on the Task 2 inspection, is shown in Figure 2.1. The individual diffusers and registers are shown in this drawing, but we have no information on their design airflow rates. The design airflow rates from the original drawings, which are different from the actual layout, were used in Table 1.1.

During the inspection of the Treatment Area it was noted that several of the smoke/fire control and inlet dampers were closed, cutting off the ventilation airflows to and/or from certain spaces. This situation was identified through visual inspection with smoke sticks and flow hood measurements at the diffusers and registers in these spaces. In some cases we were able to identify exactly which damper was closed; in other cases we could only say that it was one of several in a specific length of ductwork. In response to this finding during the October 1988 inspection, the building maintenance staff returned these dampers to their proper positions. The spaces that were affected are itemized below: 
Space 6, Lockers

Space 8, Staff Lounge

Space 9, Office

Space 10, Conference Room
No supply airflow

No supply airflow

No supply airflow

No return airflow

No supply airflow

No return airflow

There are several different dampers (both smoke control and inlet dampers) located in the supply ducts serving these rooms, and at least one of these must have been closed. There is a smoke damper located in the return air duct above Space 14, Zone \#1b (Men's Bathroom) that was closed.

Space 72, Darkroom

No exhaust airflow No supply airflow

There is a closed smoke damper in the exhaust duct serving this space. The damper is located above Space 8 (Staff Lounge).

Space 17, Linac \#1

Space 19, Linac \#2

Space 14, Male Bathrooms (2) off Changing Room

Space 21, Female Bathrooms (2)

off Changing Room
No exhaust airflow

No exhaust airflow

No exhaust airflow

No exhaust airflow

There is a smoke and an inlet damper located in the exhaust duct above Space 40, Zone \#1c (Office). One or both of these dampers were closed.

Space 22, Clean Linen

No exhaust airflow

There was a closed smoke damper located in the exhaust duct above this room.

Space 22, Clean Linen

Space 36, Dirty Linen

Space 39, Office
No supply airflow

No supply airflow

No supply airflow

There was a closed smoke damper in the supply duct serving these three spaces, located above Space 38 (Office).

Space 36, Dirty Linen

No exhaust airflow

There was a closed smoke damper in the exhaust duct serving this area, located above Space 38.

Space 23, Residents

No supply airflow

There was a closed smoke damper in the supply duct coming from the hall, Corridor D. 
Space 40, Office

No supply airflow

There was a closed smoke damper in the supply duct coming from the hall, Corridor D.

Space 48, Office

No supply airflow

There is a smoke damper and an inlet damper in the supply duct coming from the hall, Corridor F. One or both of these dampers were closed.

Space 49, Office

No supply airflow

There is a smoke damper and an inlet damper in the supply duct coming from the hall, Corridor E. One or both of these dampers were closed.

Space 34, Nurse's Station

Space 41, Exam Room A

Space 42, Exam Room B

Space 43, Exam Room C

Space 44, Exam Room D
Low supply airflow

Low supply airflow

Low supply airflow

Low supply airflow

Low supply airflow

There was a closed inlet damper, perhaps only partially closed, in the supply duct coming from the hall, Corridor $F$.

Space 56, Film Room

Space 62, Darkroom
No exhaust airflow

No exhaust airflow

There was a closed damper in the exhaust duct serving these rooms. The type and location of this damper is not clear.

The fact that so many of these dampers were closed left several spaces with little or no mechanical ventilation. Of particular concern were the two darkrooms in the Treatment Area, which should always be exhausted to the outdoors. Neither of them were being exhausted at the time of the inspection, allowing the film processing chemical fumes to migrate throughout the Treatment Area. Since the time of the HVAC inspections during the fall of 1988, all of these dampers have been reopened and the ventilation airflows to these spaces have been restored. It is not clear how long these dampers had been closed, nor how their being closed had affected the net airflow rate of the zone. 


\section{Room-by-Room Inspection}

The rooms in the ROB and the suspended ceiling plenum space was inspected for water damage, the condition of the ductwork, and agreement between the ventilation system layout as depicted in the mechanical drawings and as installed. The actual ventilation system layout generally corresponded closely to the system design, and most of the ductwork is in good condition. The exceptions that were found in the inspection are outlined below. Some of the deficiencies identified in this inspection have since been repaired and are noted as such below.

\section{Zone \#1/Treatment Area}

Space 17, Linac \#1

There are damaged ceiling tiles from a past water leak near FCU (Fan Coil Unit) \#11. The tiles are currently dry, and the leak was apparently from an old condensate drain pan. The condensate from the FCU is now carried away by a drain pipe.

FCU \#11 is drawing air from the plenum space, not from the occupied space as it was designed to do.

Space 19, Linac \#2

There are damaged ceiling tiles from a past water leak near FCU \#10. The tiles are currently dry, and the leak was apparently from an old condensate drain pan. The condensate from the FCU is now carried away by a drain pipe.

FCU \#10 is drawing air from the plenum space, not from the occupied space as it was designed to do.

Some ceiling tiles are missing.

Space 28, Linac \#3

There are damaged ceiling tiles from a past water leak near FCU \#8. The tiles are currently dry, and the leak was apparently from an old condensate drain pan. The condensate from the FCU is now carried away by a drain pipe.

FCU \#8 is drawing air from the plenum space, not from the occupied space as it was designed to do.

Some ceiling tiles are missing. 
Space 31, Control

The supply air ducts running above this space through the ceiling plenum, serving Zone \#1c, are uninsulated.

The supply air duct serving Linac \#4 is disconnected just upstream of the fan box, discharging supply air directly into the plenum space and not providing the Linac space with its ventilation air. (REPAIRED SINCE INSPECTION)

Space 69, Linac \#4 Service Area

There is an exhaust register and a supply diffuser in the sink area that is not shown on the mechanical drawings. They are shown in Figure 2.1 of this report.

\section{Space 32, Cyclotron}

There are several ceiling tiles missing.

Space 33, Linac\#4

There are two additional exhaust registers in this space, located at floor level, that are not on the drawing. They are shown in Figure 6 of this report.

Space 35, Janitor's Closet

The exhaust duct serving this space has a disconnected inlet damper, and the exhaust airflow rate out of this space is extremely high.

Ceiling Plenum above Space 45 (Planning)

The main exhaust duct collapsed in the past due to the inadvertent closing of a damper. The sides of the duct are still somewhat buckled-in, but probably not enough to significantly restrict the airflow through the duct.

Space 47, Office (406C)

The supply air diffuser in the room has been blocked off by the occupant.

There are damaged ceiling tiles from a past water leak, but they are currently dry.

There is no obvious source of the leakage.

Space 51, Physicist's Office (102C)

There are damaged ceiling tiles from a past water leak, but they are currently dry. There is no obvious source of the leakage.

Space 52, Physics Laboratory

The damper on the exhaust register has been closed by the occupant.

Some ceiling tiles are missing. 
Space 57, Simulator Control

The return air grill from this space is very dirty.

Space 64, Room 405C

Some ceiling tiles are missing.

There is a supply duct hanging from the the ceiling, with no diffusers attached, discharging air into this room.

Space 72, Darkroom

There is a film processor exhausting air from this room, and there is no design value for this exhaust airflow rate.

\section{Zone \#2/Level B3B}

Space 8, Office (47A)

There are damaged ceiling tiles from a past water leak, but they are currently dry.

There is no obvious source of the leakage.

Space 9, Office (47B)

There are damaged ceiling tiles from a past water leak, but they are currently dry. There is no obvious source of the leakage.

Spaces 8 and 9

There is a transfer grille in the wall between these two rooms that is blocked. Only Space 9 has an exhaust register and Space 8 is supposed to be exhausted by the register in Space 9 via this transfer grille. The transfer grille was blocked by the occupants to reduce noise transmission.

Space 10, Office (48)

The supply diffuser in this space has been blocked by the occupant.

Spaces 21 and 22, Office (34) and Work Lab

There is a transfer grille in the wall between these two rooms that is blocked. Space 22 has a fume hood exhaust and no exhaust register. The design intention may be to exhaust Space 21 through the fume hood in Space 22 via this transfer grille.

Space 21

The supply diffuser in this space has been blocked by the occupant. 
Spaces 22

The supply diffuser in this space has been covered with cheesecloth by the occupant based on concerns about dirt in the supply air and in an attempt to reduce the airflow rate into the room.

Space 41, Laboratory

There are wet areas on the ceiling tiles due to a leaky actuator valve on FCU \#6.

\section{Zone \#3/Level B2.5B}

Space 62, Storage Closet

There is a supply duct running through this space that is leaking air.

Zone \#4/Level $1 \mathrm{~B}$

Space 2, Office (53B)

Some ceiling tiles are missing.

Space 6,Office (51A)

There are some wet ceiling tiles in this space with water dripping from the supply air duct above the tiles.

Space 10, Office (47A)

There is a hole (about 3 inches in diameter) in the exhaust duct passing through the ceiling plenum space above this room.

Space 21, Laboratory and Space 22, Mould Lab

Each room has an exhaust register and there is no air flowing through either of them.

Space 23, Entry Way to Rooms 46 and 50

There is a register in this room that is connected to a register in the hallway by three lengths of flex-duct. None of this is shown on the mechanical drawings.

Space 31, Closet

Some ceiling tiles are missing and there are wet areas on some of the tiles.

Spaces 33 and 34, Animal Laboratories

The animal cages in these laboratories are fitted to an exhaust duct, but there are no design values for the exhaust airflow rates from these cages. 
Space 36, Laboratory

The exhaust grille in the space has been blocked off by the occupant.

Space 37, Laboratory

The exhaust duct serving this zone passes through the plenum space above the ceiling of this room, and there is a large hole in the duct pulling air from this plenum space.

Space 38, Laboratory

The design calls for a supply air diffuser in this space, but none exists.

Space 39, Hallway

There is an exhaust register pulling air from the plenum space (not the occupied space) in the hallway, outside of Room 43 . This register is not on the mechanical drawings. 


\section{Summary of Task 2 Findings}

The inspection of the ROB ventilation system identified several deficiencies in the current condition of the system. While some of these items require attention and repair, it can not be stated how they may be affecting the air quality within the occupied space without making physical measurements of airflow rates and contaminant levels. The major items identified in Task 2 are summarized below:

There are several discrepancies between the ventilation system design and installation such as the existence of registers and ductwork that are not in the mechanical drawings, for example the area around Linac \#4. There are no design values for the airflow rates for these registers for use in testing their performance. The ventilation system design documentation should updated in order to reflect these additional installations.

Many ceiling tiles are damaged from past and current water leaks. The water leaks should be repaired and the damaged tiles, as well as missing tiles, should be replaced.

The fan coil units in the ceiling plenums over Linacs \#1 through \#3 are pulling air from the plenum space and supplying this air to the occupied space. These units should be recirculating air from the occupied space, and this situation should be corrected.

Several smoke/fire control and inlet dampers in the Treatment Area were closed during the inspection, cutting off ventilation airflows to many rooms. These dampers were reopened, but their controls should be examined and a system should be developed so that future closings are quickly identified and corrected.

There are several supply air diffusers, and one exhaust air grille, that have been blocked by the occupants because of uncomfortable air speeds and noise, due to excessive airflow rates. These diffusers and grilles should be adjusted so that these spaces can be provided their design airflows without causing occupant discomfort.

There are several openings in the exhaust duct serving Level $1 \mathrm{~B}$, including an old exhaust grille located above the suspended ceiling. These openings are leading to significant airflows from the plenum space into the exhaust air system, thereby decreasing the exhaust airflow rates into the individual rooms on this level.

There is a disconnected supply air duct hanging into Space 64 , Room $405 \mathrm{C}$ in the Treatment Area. This duct should be reconnected. 


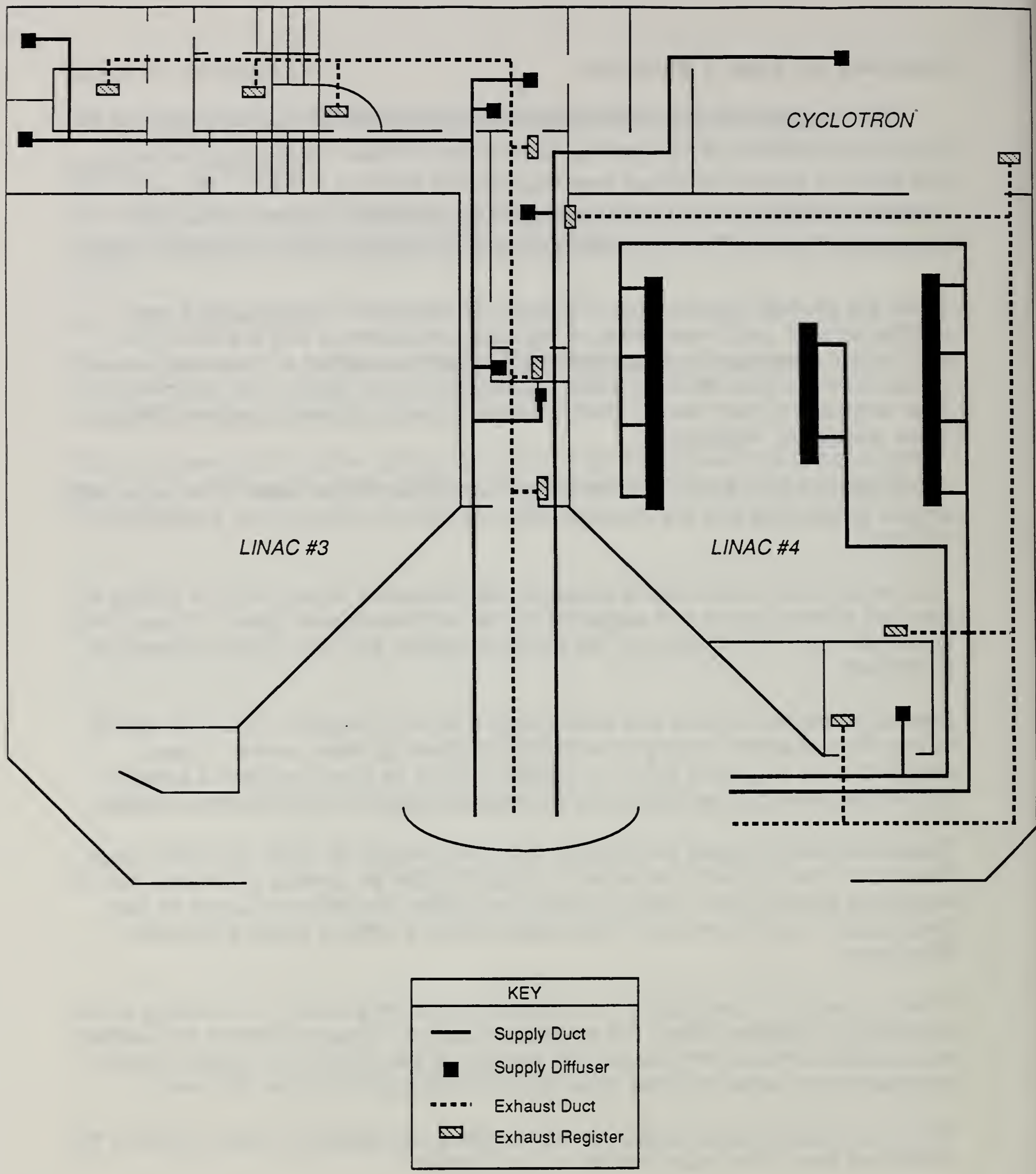

Figure 2.1 Actual Ductwork Layout in Linac \#4 Area 


\section{TASK 3: VENTILATION EVALUATION}

The third task of the NIST investigation of indoor air quality in the Radiation Oncology Branch involved the evaluation of the facility's ventilation and airflow characteristics. Ventilation is obviously an important factor with respect to indoor air quality, and ventilation standards and guidelines exist that provide recommendations on building ventilation levels intended to maintain acceptable indoor air quality (ASHRAE 1981, DHHS 1984). However, no particular ventilation rate can insure acceptable indoor air quality without the control of pollutant source strengths. The ventilation and air movement characteristics of the ROB were investigated to compare the ventilation rates in this space to the building design values and to current standards and guidelines. Other aspects of the ventilation evaluation addressed concerns about air movement between the zones of the building and the associated transport of pollutants. Ventilation rates and interzone air movement were discussed in the previous sections of this report, however, this discussion was based entirely on the ventilation system design and not on the actual ventilation performance of the building. This section addresses the measured ventilation system performance and air movement patterns for this facility.

This evaluation employed several different measurement techniques to examine different aspects of the building's ventilation characteristics, including aiflow rates in ducts, out of diffusers, and into grilles and the percent of outdoor air being brought into the building. Tracer gas techniques were used to measure some of the above quantities and to study the movement of air between zones of the building, the entrainment of building exhaust air, and the flow of air into the building from locations outside of the building. This section describes the procedures used in the ventilation evaluation of the ROB and presents the results of these measurements. These results are discussed with reference to the building ventilation system design, the ASHRAE and HHS ventilation standards, and the implications for interzone air movement and pollutant transport. 


\section{Measurement Procedures}

A variety of procedures were employed to measure airflow rates and to study the flow of air between different zones of the building and the entrainment of exhaust air by the building air intakes.

\section{Tracer Gas Measurement System}

Many of the measurements in the ventilation evaluation of the building employed tracer gas techniques, and an automated tracer gas measurement system was installed in the Treatment Area mechanical room to facilitate these measurements. This measurement system consisted of an air sampling system, a tracer gas injection system, a tracer gas monitor, and a microcomputer-based data acquisition and control system. The tracer gas that was used was sulfur hexafluoride $\left(S F_{6}\right)$, a chemically and physiologically inert gas that has been used as a tracer gas in building ventilation studies for years for safety reasons and because it is detectable at very low concentrations. In the measurements in the $\mathrm{ROB}$, the $\mathrm{SF}_{6}$ concentrations ranged from about 5 to 250 parts per billion (ppb) and were measured with a gas chromatograph equipped with an electron capture detector. The tracer gas monitor was capable of measuring the $\mathrm{SF}_{6}$ concentration of an air sample with an accuracy of about $1 \%$.

An air sampling system was used to bring air from various locations within the building to the measurement system. The air sampling system consisted of $3 / 8$ th in. OD polyethylene tubes connecting the measurement system in the mechanical room to the air sampling points in the building. Ten air sample pumps, located in the mechanical room, were used to pull air from the sampling points. An electronic valve was used to select one of the ten air sample pump outflows and direct it to the $\mathrm{SF}_{6}$ monitor. The air sampling locations that were employed in the measurements are listed in Table 3.1. They include 24 points in the occupied space, about 4 feet off the floor. Additional air sample tubes were run to various ventilation ducts in the ROB air handling systems.

The tracer gas injection system consisted of a cylinder of $\mathrm{SF}_{6}$, a solenoid valve and flowmeter to control the injection rate and duration, and a 1/8th in. $O D$ nylon tube running from the flowmeter outlet to the Treatment Area air intake vent. This arrangement enabled the automated injection of tracer gas into the Treatment Area, via the supply air distribution system. The microcomputer-based data acquisition and control system controlled the air sampling, tracer gas injection and tracer gas concentration measurement, and recorded the concentration data during the tests. 
Airflow rates were measured in ventilation system ducts, out of supply diffusers, into exhaust and return grilles, and into exhaust fume hoods. The duct airflow rate measurements were made using pitot and hot-wire traverses and a tracer gas technique using pulse injections of tracer gas. The pitot traverse measurements employed standard procedures (ASHRAE 1989) in which a pitot tube is used to measure the velocity pressure at numerous points along a crosssection of a duct, with the number of points depending on the size of the duct.

These velocity pressures were then averaged and converted to an airspeed. The average air speed was then multiplied by the cross-sectional area of the duct being measured. The measured volumetric airflow rates (in units of $\mathrm{cfm}$ ) are accurate within 1 to $5 \%$ when the air speed in the duct is greater than about $200 \mathrm{fpm}$.

In the hot-wire traverse technique a constant-temperature, hot-wire anemometer is used to measure the air speed at several locations along a crosssection of a duct, with the number of points again depending on the size of the duct. The readings are averaged, and this average air speed is multiplied by the crosssectional area of the duct to yield the volumetric airflow rate through the duct. The readings of the anemometer are accurate within $2 \%$ of full-scale, yielding airflow rate measurements with an accuracy similar to that of a pitot tube traverse. The measurement accuracy stated for both techniques applies to situations in which there are long lengths of straight ductwork upstream of the measurement point, on the order of 7.5 duct diameters from the nearest disturbance (e.g., a turn in the ductwork). Such long lengths of ductwork are rare in the field, and the measurement errors associated with traverse measurements when there is an insufficient length of ductwork are impractical to quantify. None of the traverse measurements in this building had sufficient lengths of ductwork, and the errors associated with these measurements are estimated to be $10 \%$.

Some of the duct airflow rates were measured using a tracer gas technique employing pulse injections of tracer gas. In the so-called duct pulse technique (Persily and Axley 1989), a small volume or pulse of tracer is released into the airstream in a duct over a relatively short period of time. The tracer gas concentration response is then measured downstream of the pulse. One then equates the total volume of tracer gas released with the total amount of tracer gas flowing past the downstream measurement point. If the airflow rate does not change significantly during the measurement period, usually only a few minutes, then one can solve for the airflow rate. Expressing the volumetric tracer gas injection rate as $\mathrm{G}$, the airflow rate through the duct as $\mathrm{q}$, and the tracer gas concentration at the measurement point as $C$, one can write the integral mass balance of tracer gas in the duct as 


$$
\int G(t) d t=q \int C(t) d t
$$

The airflow rate through the duct $q$ is simply the integral of the tracer gas injection rate, i.e., the amount of tracer gas injected, divided by the concentration integral. The accuracy of this technique is determined by the uncertainty in the tracer gas concentration measurement and in the measurement of the volume of the tracer gas that is injected into the duct. In the applications of the duct pulse technique in this building, the concentration integral was determined from the average tracer gas concentration at the sample location, obtained by filling an air sample bag at a constant rate during the measurement period. The integral of $G$ was simply set equal to the total volume of the tracer gas injection. Given the procedures and equipment used in this building, these measurements are accurate to within about $2 \%$.

Airflow rates out of supply air diffusers and into exhaust or return air grilles were measured with a flow hood. This device consists of a fabric hood, sized to fit over a specific diffuser, that is connected to an airflow measurement device. This device consists of a grid of hollow tubes with a pattern of regularly spaced holes and determines the airflow rate through the grid based on the velocity flowing past these sensing holes. The flow hood has four ranges, 250, 500, 1000 and $2000 \mathrm{cfm}$ full scale, and the accuracy for each range is $3 \%$ of full scale. For situations in which the location of the diffuser or grille made the use of the flow hood impossible, the velocity in the duct leading to the diffuser or grille was measured with a hot-wire anemometer. The measured air velocity was then multiplied by the cross-sectional area of the duct to yield the volumetric airflow rate.

One very important parameter in the operation of a mechanical ventilation system is the rate at which outdoor air is brought into the building by the air handlers. The outdoor air intake rate is often expressed as a fraction of the supply airflow rate, i.e., the percent of outdoor air. The air handlers serving Levels B3B, $\mathrm{B} 2.5 \mathrm{~B}$ and $1 \mathrm{~B}$ always operate at $100 \%$ outdoor air. The air handler for the Treatment Area has the capability of recirculating return air from the occupied space into the supply airstream. The Treatment Area air handling system has a design value for the minimum outdoor air intake rate of $67 \%$ of the supply air. Minimum outdoor air intake occurs when the outdoor air temperature is above $50^{\circ} \mathrm{F}$. At lower outdoor air temperatures the amount of outdoor air intake is modulated to achieve a certain supply air temperature, with the maximum outdoor air intake rate being $100 \%$ of the supply airflow rate.

The percent of outdoor air intake in the Treatment Area air handling system 
was measured with a tracer gas technique. In this procedure, sulfur hexafluoride was injected into the Treatment Area supply air duct and allowed to mix with the air in the occupied space. After about 20 minutes of mixing, the SF6 concentration was monitored in the return and supply air ducts of the Treatment Area air handling system. These concentrations were monitored every few minutes until the tracer gas concentration decreased to almost zero. The data collected during this period was fit to an equation of the form

$$
C(t)=C_{0} e^{-t / T}
$$

where $C(t)$ is the tracer gas concentration at time $t, C_{0}$ is the concentration at $t=0$, and $T$ is the system time constant. Separate equations were fit to the concentrations measured in the return and supply air ducts. These equations were then used to calculate the tracer gas concentrations in the supply and return ducts at the midpoint of the measurement period. The ratio of these two concentrations was used to determine the percent of outdoor air intake according to the following formula

$$
\% O A=1-C_{S} / C_{r}
$$

where $\mathrm{C}_{\mathrm{S}}$ is the tracer gas concentration in the supply duct and $\mathrm{C}_{\mathrm{r}}$ is the concentration in the return. It turns out that $\mathrm{SF}_{6}$ is used as an electric insulator in some of the radiation treatment machines in the Treatment Area. Because of a slow leak in one of the systems there is a constant source of $\mathrm{SF}_{6}$ in the Treatment Area. Since the leak is small and constant, the above equations are easily modified to account for this effect. Numerous measurements of the percent of outdoor air intake were made under a range of weather conditions and times of day.

\section{Zone-to-Zone Communication and Exhaust Entrainment}

As discussed earlier, airflow between the various zones of the building is a matter of concern because of the possibility of the transport of contaminants arising from the range of activities occurring in this building. For example, patients are often use the Zone \#2 hallway to get to the Treatment Area (Zone \#1), and this hallway contains several laboratories. Airflow from these laboratories to this hallway will result in these patients being exposed to the substances used in these laboratories. Interzone airflow is driven by pressure differences between building zones and occurs via many airflow paths including stair and elevator shafts, services chases, and other openings. Pressure differences arise from mechanical ventilation airflows to and from the various zones and air temperature differences 
between inside and out, referred to as the stack effect.

Interzone air movement was investigated in this building using tracer gas. In these tests, one zone was seeded with sulfur hexafluoride and the concentration response in other zones was monitored using the tracer gas measurement system. The primary zones that were considered were the four zones of the ROB, i.e., the Treatment Area (\#1), Level B3B (\#2), Level B2.5B (\#3) and Level 1B (\#4). For example, tracer gas was injected into Zone \#1 for approximately 10 minutes using the automated system and the tracer gas response in the other zones was monitored. The response was typically monitored in several rooms of the zone and in the exhaust duct of the zone. The tracer gas injections into Zones \#2 through \#4 were made by hand, using a large syringe filled with $S F_{6}$. The results of these measurements consist of a time series of tracer gas concentrations at the various sampling locations. This procedure provides a qualitative indication of air movement from the seeded zone to other zones in the building. It does not provide information on the actual airflow rate in $\mathrm{cfm}$.

Another issue of concern in the ROB is the quality of the air being brought into the building and the potential for intake air contamination by the entrainment of exhaust air. This building has numerous exhaust air systems for handling both general spaces and specific laboratories. The outlets for the $B$ corridor exhausts are located on the roof of the sixth floor of the B corridor. The air intakes for the air handlers are located on both the east and west sides of the corridor, just below roof level. The outlets of exhaust air systems should be located such that the exhaust air is carried away from the building by the wind, and there are differences in the ability of given exhaust outlet designs to perform this task (ASHRAE 1989). Locating air intakes in close proximity to exhausts aggravates the situation.

In order to investigate the existence of exhaust air entrainment by the building air intakes, tracer gas was released into the exhaust airstreams. The tracer gas concentrations at various locations in the building and its air handling systems were then monitored. The existence of entrainment leads to significant tracer gas concentrations at these sampling locations. As in the case of the interzone airflow tracer gas tests, these measurement results are strictly qualitative, indicating the existence of entrainment and not the quantity.

Similar tests were conducted to examine the existence of airflows into the building from outdoor pollutant sources such as trash dumpsters and motor vehicles parked at loading docks. In these tests $\mathrm{SF}_{6}$ was released at these outdoor locations and the concentration response was measured in the building. 


\section{Measurement Results}

This section presents and discusses the results of the ventilation and airflow evaluation of the ROB. The measurement results include mechanical ventilation system airflow rates for each of the zones and system airflow rates to and from each room. These airflow rates are discussed with reference to their design values and their implications for interzone air movement and pollutant transport. The results of the tracer gas studies of zone-to-zone communication and exhaust entrainment are also discussed.

\section{Zonal and Room Airflow Rates}

The mechanical ventilation system airflow rates to and from each zone of the $R O B$ were measured using pitot and hot-wire traverses and the pulse injection tracer gas technique. The results for the Treatment Area air handling system are presented in Table 3.2. The supply, exhaust, and return fan airflow rates were measured on several occasions between November 1988 and April 1989, and the results of each measurement are listed in the table along with the average measured value of each airflow rate. The average measured supply airflow rate is within $5 \%$ of the design value. The measured exhaust airflow rate is about 1300 cfm (14\%) below design and the return airflow rate is about $1400 \mathrm{cfm}(32 \%)$ higher than the design value. During these measurements all of the return air was being recirculated into the supply airstream, i.e., the system was operating under minimum outdoor air intake conditions. Therefore, the supply airflow rate minus the return airflow rate is equal to the outdoor air intake rate, and this value is presented in the table. The average of these calculated intake rates is about $1900 \mathrm{cfm}(20 \%)$ lower than the design value. The net mechanical airflow rate for the zone (supply minus return minus exhaust), based on the average measured airflow rates, is -500 cfm, i.e., the net system airflow is out of the zone. This compares to the design value of $300 \mathrm{cfm}$ more air being supplied to the zone than returned and exhausted. The actual net airflow rate for the zone also includes air exchange with the outdoors, with Level B3B and with Level $1 \mathrm{~B}$ via the elevator shaft.

The calculated and design values of the percent of outdoor air intake are also given in Table 3.2, and there is essentially no variation in this percentage among the different test days. As discussed earlier, the amount of outdoor air intake is supposed to be at its design minimum of $67 \%$ when the outdoor temperature is greater than $50^{\circ} \mathrm{F}$, with higher percentages being brought in when the outdoor temperature is below $50^{\circ} \mathrm{F}$. The percent of outdoor air intake was measured over a range of outdoor temperatures using tracer techniques discussed earlier. The results of these measurements are shown in Figure 3.1, which is a plot of the 
percent of outdoor air intake versus the outdoor temperature. The measured values of the percent of outdoor air are constant all the way down to about $30^{\circ} \mathrm{F}$, with an average value of $59 \%$, less than the design value and close to the calculated values in Table 3.2 .

To summarize these measurements, the Treatment Area air handling system was bringing in less outdoor air than its design value and was operating at minimum intake conditions regardless of the outdoor temperature. The total supply airflow rate was close to its design value, the exhaust airflow rate was somewhat low, and the return was high. The sum of the exhaust and return airflow rates was close to the sum of the design values, and therefore the net mechanical airflow rate for the zone was close to its design value. The fact that the exhaust airflow rate was below its design value will lead to some spaces within the zone being exhausted at lower rates than design. The return airflow rate being higher than design will lead to some rooms having higher return airflow rates than design and possibly being at a negative pressure relative to surrounding areas.

The ventilation system airflow rates to and from individual rooms were measured in the Treatment Area using a flow hood and hot-wire traverses. The results of these measurements are presented in Table 3.3, in which the zone is divided into five sections \#1a through \#1e. These tables present the design airflow rates for each room along with the corresponding measured values. The measurements of individual room airflow rates presented in these tables are generally close to their design levels with some exceptions. The measurement results that are at least $25 \%$ different from their design values are in bold type. The supply and exhaust airflow rates for all of the linacs, except for the \#4 supply, are low. Linac \#4 is also the only linac with a net positive mechanical airflow. As discussed above, many of the return airlow rates in the Treatment Area are higher than design, leading to some rooms having negative net mechanical airflow rates. All of the exam rooms (spaces 41-44) and the offices around the central core of the Treatment Area (spaces 38-40, 47-49, and 70) have higher return airflow rates than design, leading to airflow from other areas of the zone to these spaces.

Figure 3.2 is a schematic of the Treatment Area showing the results of the airflow rate measurements in each room. The numbers in each room are the net mechanical airflow rate to (positive) or from (negative) that room. As mentioned above, almost all of the offices and exam rooms in the central area of the zone have a negative net mechanical airflow rate.

The results of the individual room measurements are summarized for all of Zone \#1 in Table 3.4. The table shows the supply, exhaust, and return fan airflow rate design values and the averages of the measurements of these three quantities from Table 3.2. The sums of all of the airflow rates measured in the individual 
supply air diffusers, exhaust air grilles, and return air grilles are also shown. In all cases the measured fan airflow rates are larger than the sum of the individual diffusers and grilles connected to these fans. This difference is an indication of duct leakage in all three distribution systems. This leakage corresponds to about $18 \%$ of the supply airflow rate, $16 \%$ of the exhaust, and $28 \%$ of the return. The table also lists the sum of all of the individual supply, exhaust and return diffuser and grille design airflow rates, which is incomplete in that design values were not available for all of the individual grilles and diffusers. These values are followed by the sum of the measured airflow rates for only those diffusers and grilles for which there was a design airflow rate. The sum of these measured airflow rates are less than the sum of the corresponding design values, again presumably due to air leakage from the ductwork.

Table 3.5 presents the ventilation system airflow rate measurements for Zones $\# 2$ and \#3. The supply fan serving these zones is located on the roof of the sixth floor mechanical room in the $B$ corridor. The supply duct from this fan passes through the mechanical room on its way down to Levels B2.5B and B3B. Measurements of the supply airflow rate were made at two locations in this duct, one on the roof and the other within the mechanical room. Both of the locations were almost immediately downstream of turns in the ductwork, and therefore the hot-wire traverse measurements are not expected to be especially accurate. The results in the table show that the measurements in the mechanical room are consistently higher than those on the roof, probably due to the airflow conditions within the duct at these locations. The tracer pulse measurement on 4/7/89 involved the entire length of ductwork from the roof into the mechanical room, and the value obtained with this measurement technique is between the other two results. The average measured value for the supply airflow rate is $14,200 \mathrm{cfm}$, compared to the design value of $11,000 \mathrm{cfm}$. Therefore, this fan is moving about $30 \%$ more air than its design value.

Levels B2.5B and B3B are exhausted by the B corridor general exhaust system. There are separate exhaust ducts serving the east and west sides of the two floors, and the airflow rates through these ducts were measured using hot-wire traverses. The results of these measurements are given at the bottom of Table 3.5. The sum of these two measured airflow rates is almost $1000 \mathrm{cfm}$ greater than the design airflow rate, which is based on the sum of the individual exhaust grille airflow rates. As in the case of the supply airflow rate measurement for Levels B2.5B and B3B, the hot-wire measurement locations are not optimal in terms of ductwork configuration upstream of the measurement plane, and therefore the measured airflow rates are not expected to be very accurate.

Table 3.6 presents the results of the ventilation airflow rate measurements in the individual rooms on Levels B2.5B and B3B. The results are divided into four 
sections, a through d, corresponding to the east and west sides of Levels B2.5B and $\mathrm{B} 3 \mathrm{~B}$. The measurement results that are at least $25 \%$ different from their design values are in bold type. Comparison of the design and measured airflow rates for the individual rooms reveals many significant differences, especially for the exhaust airflow rates. The southeast portion of Level B3B tends to have low exhaust airflow rates compared to design, as does the entire west side of Level B2.5B. Most of the rooms on the west side of Level B3B have higher supply airflow rates than design. Of particular concern is the darkroom on Level B3B-West (space 19 in room B3B36), which is oversupplied, causing air to flow out of the darkroom instead of being exhausted. In three rooms on Level B3B-West the supply air diffusers have been blocked off by the occupants due to excessive airflow rates and noise, and despite these efforts the supply airflow rates in two of these rooms (B3B34 and B3B32) are still above design.

Figures 3.3 and 3.4 are schematics of Levels B3B and B2.5B showing the results of the airflow rate measurements in each room. The numbers in each room are the net mechanical airflow rate into (positive) or from (negative) that room. These net airflow rates neglect any other airflows to or from these rooms from other than the mechanical systems. The arrows in the figures show the direction of airflow into or out of each doonway based on the measured mechanical ventilation airflows only. These figures show that the direction of the airflows from many laboratories are into the hall, when they should be flowing the other way. This airflow reversal leads to the transport of contaminants from the laboratories to the hallways and other areas in the building. Such contaminant transport to the hall is of particular concern on Level B3B because many patients are taken to the Treatment Area via this hallway. All of the offices on these two levels have positive airflows relative to the halls, reducing the contaminant transport from the halls to the offices, although there will still be some residual transport from the halls into these rooms.

The individual room airflow rate measurements for Levels $\mathrm{B} 2.5 \mathrm{~B}$ and $\mathrm{B} 3 \mathrm{~B}$ are summarized in Table 3.7. This table shows the sum of the specified airlow rates and the sum of the measured airflow rates for the east and west sides of Levels $\mathrm{B} 2.5 \mathrm{~B}$ and $\mathrm{B} 3 \mathrm{~B}$. The design and actual values of the supply airflow rates are close to each other, except on Level B3B-West in which the measured airflow rates are about $700 \mathrm{cfm}$ higher. The total measured supply airflow rate for both levels is given as $8345 \mathrm{cfm}$ which is about $600 \mathrm{cfm}$ above the design value. However, this total of the delivered supply airflow rate is much less than the average aiflow rate measured at the supply fan; in fact it is about $40 \%$ less. This difference is an indication of air leakage from the supply air duct.

Table 3.7 also summarizes the airflow rate measurements on Levels $B 2.5 B$ 
and B3B for the exhaust air grilles and the laboratory fume hoods. The measured exhaust airflow rates are well below their design values, particularly on Level B3BEast and Level B2.5B-West. The total exhaust airflow rate for the two levels is about $1600 \mathrm{cfm}$ ( $31 \%$ ) below design and about $2400 \mathrm{cfm}$ ( $40 \%$ ) below the measurement in the duct given in Table 3.5. This difference between the aiflow rates at the diffusers and the airflow rate in the main exhaust duct is an indication of a significant amount of duct leakage. The fume hoods are operating close to their design airflow rates.

The bottom of Table 3.7 lists the net airflow rates for the east and west sides of Levels $\mathrm{B} 2.5 \mathrm{~B}$ and $\mathrm{B} 3 \mathrm{~B}$, based on both the design and the measured values. Because of the modification in the supply fan serving these two floors, the measured airflow rates indicate an oversupply of these two levels, except on the east side of Level B2.5B. This excess of supply air is aggravated by the low exhaust airflow rates relative to the design values.

Table 3.8 lists the results of the ventilation airflow rate measurements in the rooms on Level 1B, and Figure 3.5 shows the net airflow rates for each room in schematic form. The measurement results that are at least $25 \%$ different from their design values are in bold type in the table. Several of the measured room airflow rates differ significantly from the design values, with a tendency towards the exhaust airflow rates being below design. On the east side of the floor, spaces 1 through 19, the exhaust flows are particularly low, especially in the southeast corner. Several of the laboratories have net airflows into the hall, resulting in the transport of contaminants to this common area and elsewhere in the building. The mould room (space 22, room 1B52) has an insufficient exhaust airflow rate, which is of particular concern given the substances used in this room. Many patients on the way to the Treatment Area use the 1B hallway and are exposed to whatever contaminants are flowing from these rooms into the hall.

The individual measurements are summarized at the bottom of Table 3.8 where the sum of the design flows are compared to the sum of the measured flows. The total supply airflow rate is close to its design, while the measured exhaust airflow rate is about one-half of its design value. There is a large hole in the exhaust duct for this zone, located above the ceiling of space \#37, which is pulling in about $1100 \mathrm{cfm}$ from the space above the ceiling. In addition, there is an old exhaust grille above the ceiling in the hallway, located outside of space \#13, exhausting about $700 \mathrm{cfm}$ from the space above the ceiling. Adding these two exhaust airflows to the sum of the measured airflow rates from the room exhaust grilles results in a total exhaust airflow that is close to the design value. 
The movement of air between the zones of the building, and the associated transport of contaminants, is an issue of concern in this facility. In order to investigate the existence and direction of interzone aiflow, a series of tracer gas and smoke tests were conducted. In addition, tracer gas testing was conducted to examine the entrainment of building exhaust air by the air handler intakes and airflow into the building from outdoor sources of contaminants.

Air movement between the four zones of the ROB was examined by releasing tracer gas in one of the zones and monitoring the tracer gas concentration response in all of the zones using the automated tracer gas measurement system. Figure 3.6 shows the results for two tests in which sulfur hexafluoride was injected into the Treatment Area (Zone \#1) supply air system. In the first test the tracer gas was injected during unoccupied hours, when most office and laboratory doors were closed. Other than the Treatment Area itself, characterized by the Zone \#1 average concentration, the tracer is seen only at air sample location 2/46 in the hallway of Level B3B. (In these discussions, a sample location designation consists of a zone number and a space number or description separated by a slash.) All of the rooms on this level, and the exhaust duct which serves them, show no measurable tracer gas concentration. Though not shown in this plot, there was no tracer gas response on Levels $\mathrm{B} 2.5 \mathrm{~B}$ or $1 \mathrm{~B}$

The second plot in Figure 3.6 shows the results of an $\mathrm{SF}_{6}$ injection into the Treatment Area during the day, when most of the office and laboratory doors to the hallway are open. Again we see tracer in the Level B3B hallway, but this time we also see a concentration response in several of the rooms on this level. The highest concentrations are in space $2 / 29$, a laboratory for which the measured ventilation flows indicated that the ventilation of this space was dominated by exhaust. Therefore, air and tracer gas flows from the hall into this space. All of the other rooms shown in this plot have an excess of supply airflow relative to exhaust, and therefore they have relatively low tracer gas responses. Even though these spaces have an excess supply airflow, a small amount of tracer gas still gets into these rooms due to turbulence at doorways and other variations in the average airflow patterns. There was no measurable tracer gas response on Levels $B 2.5 B$ (Zone \#3) and $1 \mathrm{~B}$ (Zone \#4) in this second test, again indicating no significant airflow from the Treatment Area to these two levels. These two tests show that air moves from the Treatment Area to the Level B3B hallway, but not to Levels B2.5B or $1 B$. Whether air flows from the B3B hallway to individual rooms on this level depends on whether the door to the room is open and on the sign of the net mechanical ventilation airflow rate for that room. 
The three plots in Figure 3.7 show the tracer gas response to an injection into the supply duct serving Zones \#2 and \#3. In the first plot we see that there is no response to this injection in either the Treatment Area or on Level 1B. The low, but constant, $\mathrm{SF}_{6}$ concentration in the Treatment Area exhaust is due to a small $\mathrm{SF}_{6}$ leak in one of the radiation treatment machines. The response to this injection in the individual rooms in Zones \#2 and \#3 are shown in the other two plots of Figure 3.7. These room responses are relatively uniform, indicating that the supply air is well distributed among the rooms.

Figure 3.8 shows the tracer gas response within the $R O B$ to an injection into the hallway of Level $1 \mathrm{~B}$. The first plot shows that there is no response in any of the other ROB zones. The second plot shows the response in individual rooms on Level 1B. As expected, those rooms which have an excess of exhaust airflow relative to supply have more significant tracer gas responses than those which are oversupplied.

These tracer gas tests indicate that air flows from the Treatment Area to the Level B3B hallway, and that there are no other significant airflows between any of the other zones of the ROB. The fact that air flows from the Treatment Area to Level $\mathrm{B} 3 \mathrm{~B}$, and that there is a large excess of supply airflow to Levels B3B and B2.5B, leads to the question of where this extra supply air goes to from these levels. These circumstances seem to indicate that air flows within the building through paths other than those associated with the mechanical ventilation system, such as the stair and elevator shafts of the B corridor. Smoke tests were conducted to investigate the direction of airflow between the zones of the ROB and these vertical shafts, and Figure 3.9 shows the results of these smoke tests. These tests indicate that air flows from the hallways on all three ROB levels into the stair and elevator shafts. These tests also indicate that air flows from the Treatment Area into the Level B3B hallway, consistent with the results of the tracer gas tests. On Level $\mathrm{B} 3 \mathrm{~B}$, air from the hallway also flows to the elevator lobby at the north end of the hall. On Level 1B air flows into the hallway from the elevator lobbies at both ends of the hallway, but air still flows from the hallway into the stair and elevator shafts. Therefore, air flows from these three floors into all of the available vertical shafts, preventing any significant airflows between these floors.

This tendency for air to flow from these floors to the stair and elevator shafts appears to be caused by strong exhaust airflows on other levels in the B corridor that pull air from these shafts, resulting in their being at a strong negative pressure. Other floors in the corridor, particularly B2B (an animal facility), do have very powerful exhaust air systems. Additional smoke testing was conducted in the stair shafts of the B corridor and the results are presented schematically in Figure 3.10. This figure shows the direction of the airflows to and from the two stair shafts and the $B$ corridor and other portions of Building 10. The solid black arrows indicate 
airflow from the stair shaft to the space, while the gray arrows indicate airflow to the shaft from the space. On most of the floors, air flows from the stair shafts to the space, presumably due to strong exhaust airflows on these floors. These airflows result in the shaft being at a negative air pressure, inducing airflow to the shafts on the other floors, including those of the ROB. Therefore, any airborne contaminants in the ROB are most likely either generated in the facility or are the result of contaminated intake air. An exception to this would occur on Level 1B which has airflow into the hallway from the north elevator lobby. While this airflow pattern is similar to that induced by a stack or temperature effect, these tests were conducted in May when the interior temperature was below the outdoor temperature.

Therefore, this pattern is probably induced by the mechanical exhaust flows in the building.

The impact of the excess mechanical supply airflow over exhaust on Levels $\mathrm{B} 3 \mathrm{~B}$ and $\mathrm{B} 2.5 \mathrm{~B}$, or its correction, is not clear. If these ventilation airflows were modified such that the laboratories on these two levels were exhaust dominated, it is not clear where the "make-up" air for these exhaust airflows would come from. It is conceivable that making these laboratories exhaust dominated could pull air, and possibly contaminants, from other portions in the building to Levels $B 3 B$ and $B 2.5 B$ of the ROB via the stair and elevator shafts.

Additional tracer tests were conducted to investigate air movement from outdoor locations containing contaminant sources to the occupied space of the $R O B$, and to investigate the entrainment of building exhaust air. As in the interzone tracer tests, $\mathrm{SF}_{6}$ was released at selected locations and the concentration response in the ROB was monitored. Figure 3.11 is a floor plan of the B1 level of the Treatment Area and the B corridor, showing several locations at which contaminant and odor sources exist, including the Treatment Area exhaust grille, the trash dumpsters, and the loading docks. Several paths for the transport of these contaminants into the ROB can be identified in the schematic including the intake grille for the Treatment Area air handling system, the outside doors to stair shafts \#4 and \#5, and the two loading docks themselves. In addition, the air intakes for the $B$ corridor are located on the east and west sides of this corridor at the sixth floor level at roughly the midpoint of the corridor.

Tracer gas pulses were released at three different locations and the concentration response was measured in the ROB. These injection locations include the loading dock by stairway \#5 at the north end of the $B$ corridor. This location is associated with motor vehicle exhaust and trash dumpsters, and the possibility exists for contaminants to enter the building through the loading dock and the outside door into the stairway. Tracer gas was also released near the cafeteria loading dock which is associated with motor vehicle exhaust and the trash 
dumpsters by stairway \#4. Contaminants from these sources can enter the building through the loading dock, the outside door to stairway \#4, and the Treatment Area air intake. Finally, tracer gas was injected into the Treatment Area exhaust airstream in order to determine whether this exhaust air was being entrained by the air intake around the corner from the exhaust. The results of all of these tracer gas tests are clearly dependent on the weather and building operation conditions that exist during the test. Under different conditions, the test results may be different.

Figure 3.12 shows the tracer gas response in the four zones of the ROB to an injection of $\mathrm{SF}_{6}$ at the loading dock by stairway \#5. There is a strong response in Zone \#4 (Level 1B), but no response anywhere else in the ROB. Therefore, air and contaminants are transported from this area to Level 1B. This air enters the building through the loading dock and probably travels to Level $1 \mathrm{~B}$ via the freight elevator shafts. The airflow to the 1B hallway from the north elevator lobby (see Figure 3.9) provides a means by which the air and contaminants can enter the $1 \mathrm{~B}$ level.

Figure 3.13 shows the tracer gas response to an injection at the cafeteria loading dock. The first plot shows a very strong response in the Treatment Area with a lesser response on Level 1B. Levels B3B and B2.5B exhibit even lower responses to this tracer gas injection. The second plot gives an indication of how the tracer gas gets into the ROB. This plot shows a very strong response in the Treatment Area mechanical room, but essentially no tracer gas in the Treatment Area air intake. Therefore the tracer gas is not getting into the Treatment Area through the air intake system. It is getting into the mechanical room, presumably through a ventilation grille for the penthouse located in the wall, near the exhaust grille. Once in the mechanical room, this air can get into the Treatment Area via leaks in the return air ductwork or other airflow paths. A small concentration response is seen in the supply duct serving Zones \#2 and \#3, indicating that some of this tracer gas is being entrained by the air intake of the supply fan serving these two zones.

Figure 3.14 shows the tracer gas response in the ROB to an injection of $\mathrm{SF}_{6}$ into the exhaust of the Treatment Area. The first plot shows that there are significant concentration responses in all four zones of the ROB, with the largest concentrations in the Treatment Area. The second plot shows the concentration response in the Treatment Area mechanical room, the Treatment Area air intake and the supply duct for Zones \#2 and \#3. Very high SF 6 concentrations were measured in the mechanical room, with a very low response in the Treatment Area air intake. As in the case of the tracer gas injection at the cafeteria loading dock, the tracer does not move into the Treatment Area via the air intake, but rather it flows into the mechanical room and then into the space. A low concentration response is seen in the supply air duct for Zones \#2 and \#3, indicating a small 
amount of entrainment of the Treatment Area exhaust into this air handling system. However, the concentrations in these two zones in the first plot of Figure 3.14 indicate that tracer is getting into these zones via pathways other than the air handling system.

These three tracer gas tests indicate the existence of airflows from outdoor sources of contaminants into the occupied space of the ROB. Air from these outdoor locations appears to be entering the building through doorways, loading docks, and the ventilation grille in the Treatment Area mechanical room wall. The movement of this air into and within the building is complex and not completely understood, but appears to be driven at least in part by large exhaust airflows in the $B$ corridor, causing the space to be at a negative pressure relative to the outdoors. As mentioned earlier, these airflow patterns are affected by weather conditions and the operation of the mechanical ventilation equipment, and they could be quite different under different conditions.

Another issue of concern in this building is the entrainment of exhaust air by the building air intakes. This was investigated for the Treatment Area and found not to occur at the time of the test, although the exhaust air entered the zone through other means. Exhaust air entrainment was also investigated for the $B$ corridor air handling systems. There are numerous exhaust outlets on this roof, some of them associated with the corridor's general exhausts and others from specific laboratories and fume hoods. As mentioned earlier, the air intakes for the corridor are located just below roof level on both sides of the B corridor, close to the exhaust vents. Exhaust air entrainment is always undesirable, and the situation is somewhat more critical in this building given the substances being exhausted by some these systems.

Tracer gas was injected into the outlets of two of the exhaust systems on the roof of the sixth floor mechanical room. The results of these tracer gas tests are shown in Figure 3.15. The first plot is for a situation in which the exhaust outlet discharged upward with a high air velocity. This is a good exhaust outlet design [ACGIH 1982], and as can be seen in the plot, there is no tracer gas response in the space. The second plot in Figure 3.15 is for a tracer gas injection into an exhaust outlet which points down. Such a "gooseneck" design is intended to avoid rain falling into the system, but it tends to perform poorly in terms of getting the exhaust air away from the building. The results show a large tracer gas response on Level 1B, with lesser responses on Levels B3B and B2.5B. Additional tests, not shown here, show the same effects, i.e., exhaust air systems which discharge upward do not result in any significant exhaust air entrainment. Airflow from systems which discharge downward gets entrained by the building air intakes. Exhaust air entrainment in this building is a potentially serious problem given the 
substances being exhausted by some of these systems. This entrainment can also explain some of the odor complaints in the space.

\section{Summary of Task 3 Findings}

The measurements of airflow rates and air exchange characteristics in the ROB revealed some significant differences between the system design and its actual performance, as well as other important factors related to air exchange and air movement in the facility. These findings of the ventilation evaluation are summarized in this section.

The measurements of the Treatment Area air handling system showed that the supply airflow rate was close to its design value, the exhaust fan airflow rate was about $1300 \mathrm{cfm}(14 \%)$ below design, and the return fan was about $1400 \mathrm{cfm}(32 \%)$ above design. These differences imply that there is insufficient exhaust from some of the rooms of the Treatment Area and excessive return airflow rates from others. Such a situation could lead to ineffective removal of contaminants from the spaces with low exhaust airflow rates. In rooms with high return airflow rates, air can be drawn into these rooms from the surrounding areas, potentially bringing contaminants into these spaces. The measurements also showed that the outdoor air intake rate for the Treatment Area was about $1900 \mathrm{cfm}(20 \%)$ below the minimum intake design value, and it was always operating at minimum intake during the measurements. A significant amount of duct leakage was noted in the air handling system: supply air $18 \%$, exhaust air $16 \%$, and return air $28 \%$. Air leakage in the supply air duct results in lower airflows to individual rooms, including lesser amounts of outdoor air. The return air duct leakage is a matter of particular concern because this leakage presumably occurs in spaces such as ceiling plenums, service chases, and equipment rooms. These spaces are generally quite dirty and the air that leaks into the return ducts from these spaces is recirculated into the supply airflow, along with any contaminants picked up from these spaces.

The measurements of mechanical ventilation airflow rates in the individual rooms of the Treatment Area revealed many differences between design and actual airflow rates. At least some of these differences are due to the differences between the actual and design airflow rates of the return and exhaust fans. These differences are itemized in Tables 3.3, 3.6 and 3.8. In particular the ventilation airflow rates to Lnacs \#1 through \#3 and to the Simulator are well below their design values. The central offices and examination rooms in the Treatment Area have excessive return airflow rates, although the design calls for a balance of the supply and return ventilation airflow rates in these rooms.

The supply fan serving Levels $\mathrm{B} 3 \mathrm{~B}$ and $\mathrm{B} 2.5 \mathrm{~B}$ has an airlow rate that is about 
$30 \%(3200 \mathrm{cfm})$ above its design value. The exhaust air system is moving about $1000 \mathrm{cfm}$ less than design. There is also a significant amount of duct leakage in these two systems, about $40 \%$ in each. As in the Treatment Area, there are many rooms on these two levels with significant differences between the design and measured airflow rates at the supply diffusers and the exhaust grilles. The southeast portion of Level B3B tends to have low exhaust airflow rates compared to design, as does the entire west side of Level B2.5B. Most of the rooms on the west side of Level B3B have higher supply airlow rates than design. Three rooms on Level B3B-West have such high supply airflows rates that the occupants have attempted to block off the diffusers. Most of the laboratories on these two levels are at a positive pressure relative to the hallway because of the excessive supply airflow rates. Some of these cases of oversupplied laboratories are presumably due to the modification of the supply air fan without an accompanying change in the exhaust air system. This situation leads to contaminant transport from the laboratories to the hallway, where building occupants, including patients on their way to the Treatment Area, are exposed to these substances.

On Level 1B, many differences were detected between the design and actual ventilation airflow rates to and from individual rooms. The exhaust airflow rates were low on the east side of the floor, particularly in the southeast corner. The mould room has an insufficient exhaust airflow rate, leading to the transport into the hallway of the substances associated with the mould-making process. Some of the laboratories on this level have an excess of supply air, also leading to airlow into the hallway. Many of the room exhaust airflow rates are low because of a large hole in the exhaust duct and an old exhaust grille located above the ceiling.

Tracer gas and smoke tests were conducted to examine interzone air movement and the entrainment of exhaust air into the building air intakes. Within the ROB, air flows from the Treatment Area to the Level B3B hallway, and the air from all three of the $B$ corridor hallways flows into the stair and elevator shafts. These shafts are depressurized relative to the ROB space presumably because of large mechanical exhaust airflow rates on the other floors of the B corridor and the rest of Building 10. Air is being pulled from these shafts on these other floors, causing the shafts to be at significant negative pressures relative to the floors of the ROB.

The movement of air, and potentially contaminants, into the ROB from several outdoor pollutant sources was examined with tracer gas testing. These tests showed that there was airflow from the loading dock by stair \#5 to Level 1B, presumably via the freight elevator shaft. Airflow from the cafeteria loading dock to the Treatment Area was also identified, although it was not coming in through the Treatment Area air intake. Instead air from the loading dock was pulled into the 
zone's mechanical room through a grille in the wall, and then flowed into the building interior though other paths. Lesser amounts of airflow to Levels $1 \mathrm{~B}, \mathrm{~B} 2.5 \mathrm{~B}$ and $\mathrm{B} 3 \mathrm{~B}$ were also seen from the cafeteria loading dock. Treatment Area exhaust air was also observed to flow into the occupied space of the Treatment Area. As in the case of the cafeteria loading dock it was not entrained by the air intake, but entered through a grille in the mechanical room wall. Some of the Treatment Area exhaust air was also seen in the rest of the ROB. Entrainment of exhaust air from the numerous exhaust air systems on the roof of the B corridor was also examined. Tests of an exhaust outlet pointing upward from the building showed that this outlet design did not result in significant exhaust air entrainment by the $B$ corridor air handling systems. Tests of an outlet pointing downward revealed significant amounts of entrainment, enabling contaminant transport to the occupied space of the $\mathrm{B}$ corridor.

The ventilation evaluation of the ROB uncovered differences between the design and actual airflow rates in the air handlers serving the facility as well as in the ventilation airflows to and from individual rooms. These conditions contribute to many of the laboratories being at a positive pressure relative to the hallway, creating the possibility for contaminant transport from the laboratories into the hallways. In addition, significant amounts of duct leakage were noted in the air handling systems. Tracer gas and smoke visualization tests demonstrated the potential for significant air movement and contaminant transport within the building and from outdoor pollutant sources (including exhaust airstreams) to spaces in the ROB. 
Table 3.1 Air Sample Locations

\begin{tabular}{|c|c|c|}
\hline SPACE \# & ROOM \# & DESCRIPTION \\
\hline \multicolumn{3}{|c|}{ TREATMENT AREA } \\
\hline$\overline{10}$ & 85 & Nurse's Conference Room \\
\hline 24 & - & Waiting Area \\
\hline 34 & 200 & Nurse's Station \\
\hline 52 & - & Hallway \\
\hline 57 & $413 B$ & Simulator Control \\
\hline 70 & 101 & Secretaries' Area \\
\hline - & - & Supply Air Duct \\
\hline - & - & Return Air Duct \\
\hline - & - & Exhaust Air Duct \\
\hline - & - & Outdoor Air Intake Grille \\
\hline \multicolumn{3}{|l|}{ LEVEL B3B } \\
\hline 8 & B3B 47 & Office \\
\hline 10 & B3B 48 & Office \\
\hline 21 & B3B 34 & Office \\
\hline 29 & В3В 35 & Laboratory \\
\hline 46 & - & Hallway - South \\
\hline 23 & - & Hallway - North \\
\hline - & - & B3B/B2.5B Exhaust Air Duct - East \\
\hline- & - & B3B/B2.5B Exhaust Air Duct - West \\
\hline \multicolumn{3}{|l|}{ LEVEL B2.5B } \\
\hline 57 & B2.5B 38 & Conference Room \\
\hline 66 & B2.5B 35 & Laboratory \\
\hline 77 & $82.5 B 53$ & Office \\
\hline 46 & - & Hallway - South \\
\hline 62 & - & Hallway - North \\
\hline - & - & B3B/B2.5B Supply Air Duct - East \\
\hline \multicolumn{3}{|l|}{ LEVEL $1 B$} \\
\hline 7 & 1B 47C & Office \\
\hline 18 & 18378 & Office \\
\hline 22 & 1852 & Mould Laboratory \\
\hline 23 & 1850 & Laboratory \\
\hline 39 & - & Hallway - South \\
\hline 19 & $\cdot$ & Hallway - North \\
\hline & & 1B Exhaust Air Duct \\
\hline
\end{tabular}


Table 3.2 System Airflow Rates for Treatment Area (cfm)

\begin{tabular}{|c|c|c|c|c|c|c|}
\hline $\begin{array}{c}\text { DATE } \\
\text { MEASURED }\end{array}$ & TECHNIQUE & $\begin{array}{c}\text { SUPPLY } \\
\text { AIRFLOW } \\
\text { RATE } \\
\end{array}$ & $\begin{array}{c}\text { EXHAUST } \\
\text { AIRFLOW } \\
\text { RATE } \\
\end{array}$ & $\begin{array}{l}\text { RETURN } \\
\text { AIRFLOW } \\
\text { RATE } \\
\end{array}$ & $\begin{array}{c}\text { OUTDOOR } \\
\text { AIR INTAKE } \\
\text { RATE* }\end{array}$ & $\begin{array}{c}\text { PERCENT } \\
\text { OUTDOOR } \\
\text { AIR INTAKE } \\
\end{array}$ \\
\hline $11 / 21 / 88$ & $\begin{array}{c}\text { Pitot } \\
\text { Hot-Wire }\end{array}$ & $\begin{array}{l}13,500 \\
13,100\end{array}$ & $\begin{array}{l}7,800 \\
7,800\end{array}$ & $\begin{array}{l}5,800 \\
6,000\end{array}$ & $\begin{array}{l}7700 \\
7100\end{array}$ & $\begin{array}{l}57 \% \\
54 \%\end{array}$ \\
\hline $2 / 21 / 89$ & $\begin{array}{c}\text { Pitot } \\
\text { Hot-Wire }\end{array}$ & $\begin{array}{l}13,000 \\
13,000\end{array}$ & - & : & - & . \\
\hline $3 / 8 / 89$ & $\begin{array}{c}\text { Pitot } \\
\text { Hot-Wire }\end{array}$ & $\begin{array}{l}12,700 \\
13,700\end{array}$ & $\begin{array}{l}7,900 \\
8,100\end{array}$ & $\begin{array}{l}5,400 \\
6,200\end{array}$ & $\begin{array}{l}7300 \\
7500\end{array}$ & $\begin{array}{l}57 \% \\
55 \%\end{array}$ \\
\hline $3 / 30 / 89$ & Hot-Wire & 14,200 & - & - & - & - \\
\hline $4 / 4 / 89$ & $\begin{array}{l}\text { Tracer Gas } \\
\text { Pulse } \\
\text { Hot-Wire }\end{array}$ & 13,400 & 8,300 & 5,700 & 7700 & $57 \%$ \\
\hline \multicolumn{2}{|l|}{ AVERAGES } & 13,300 & 8,000 & 5,800 & 7,500 & $56 \%$ \\
\hline \multicolumn{2}{|c|}{ DESIGN SPECIFICATIONS } & 14,000 & 9,300 & 4,400 & 9,380 & $67 \%$ \\
\hline
\end{tabular}

- Calculated by subtracting the return airflow rate from the supply airflow rate 


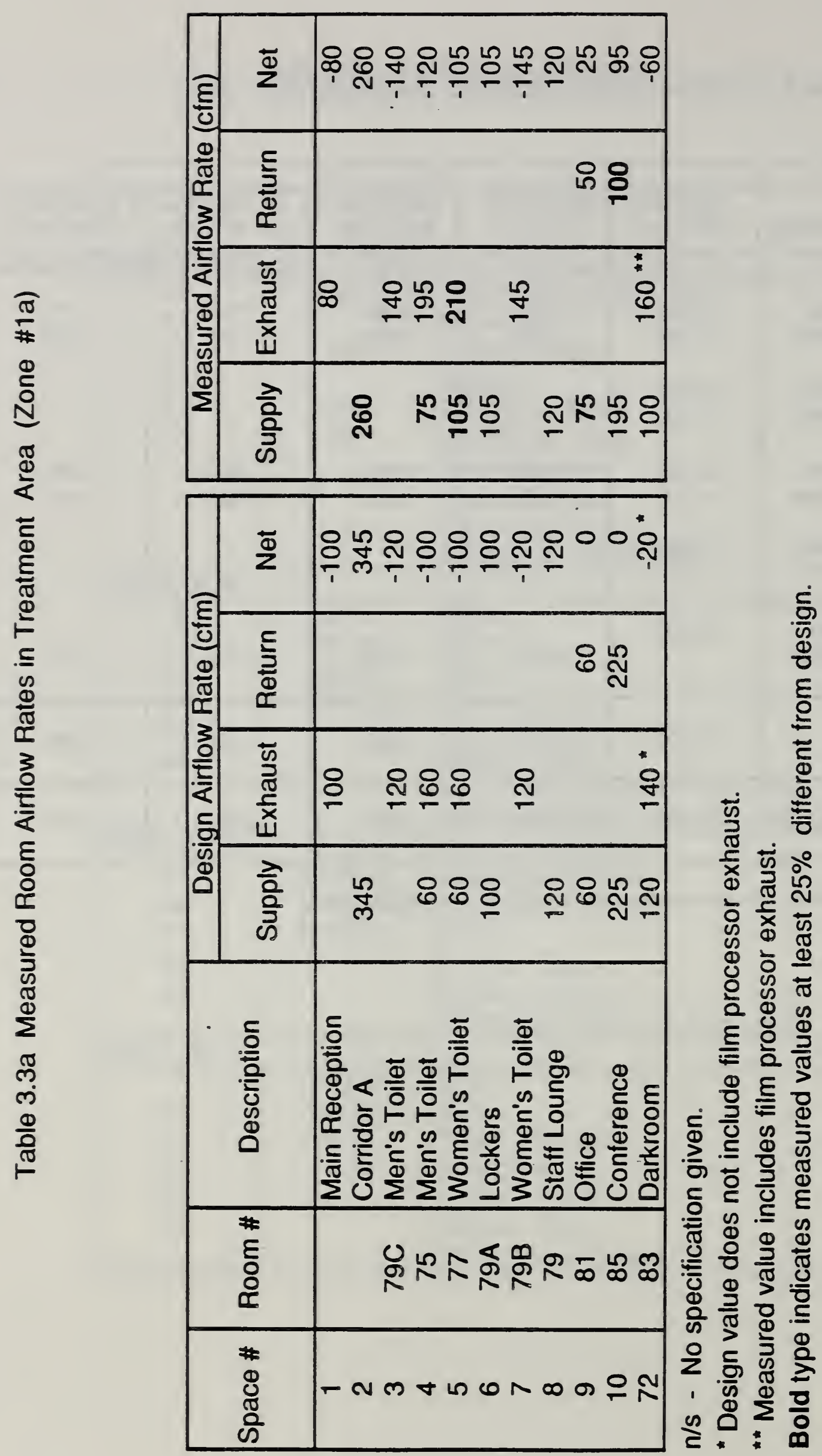




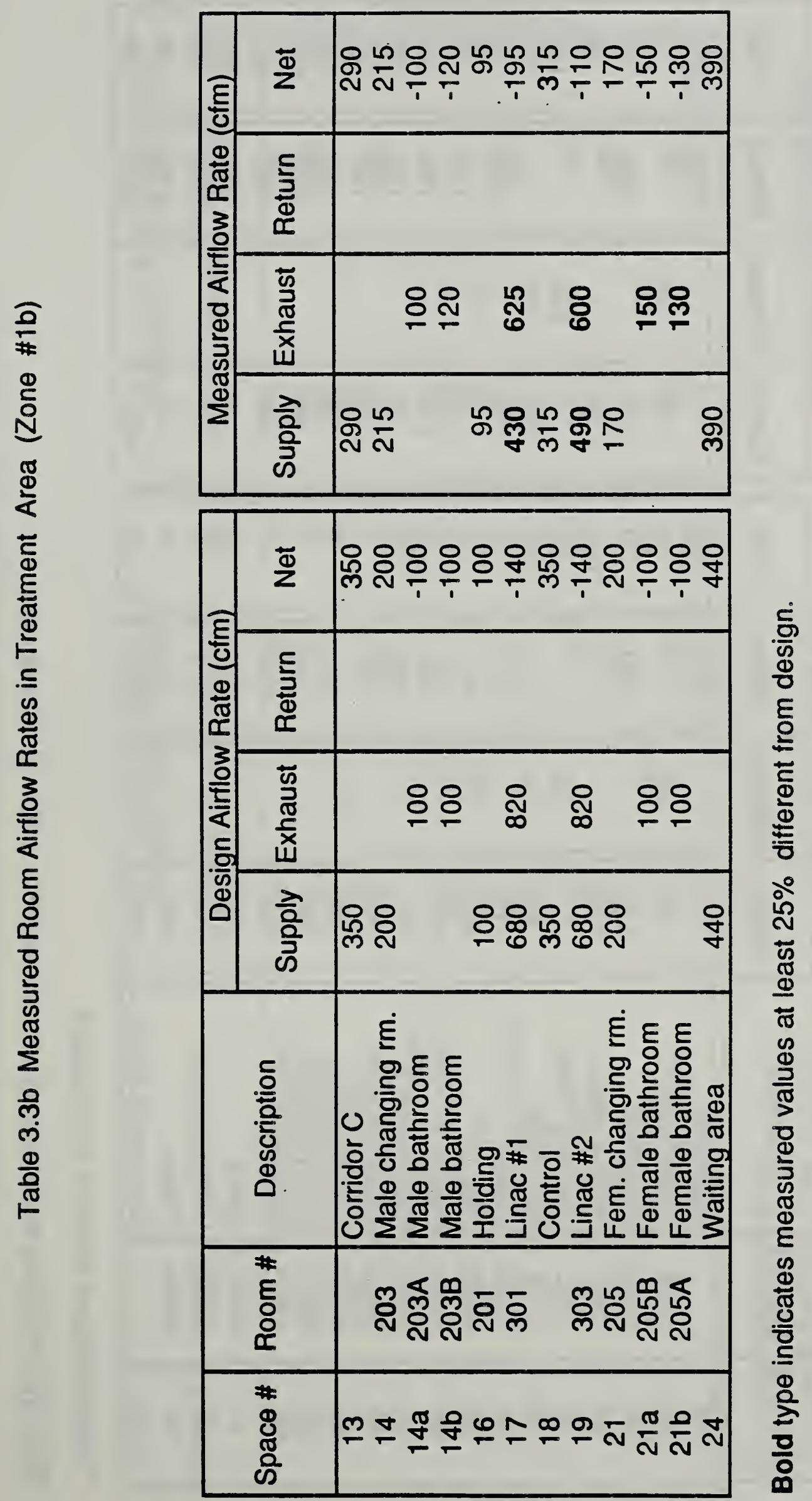




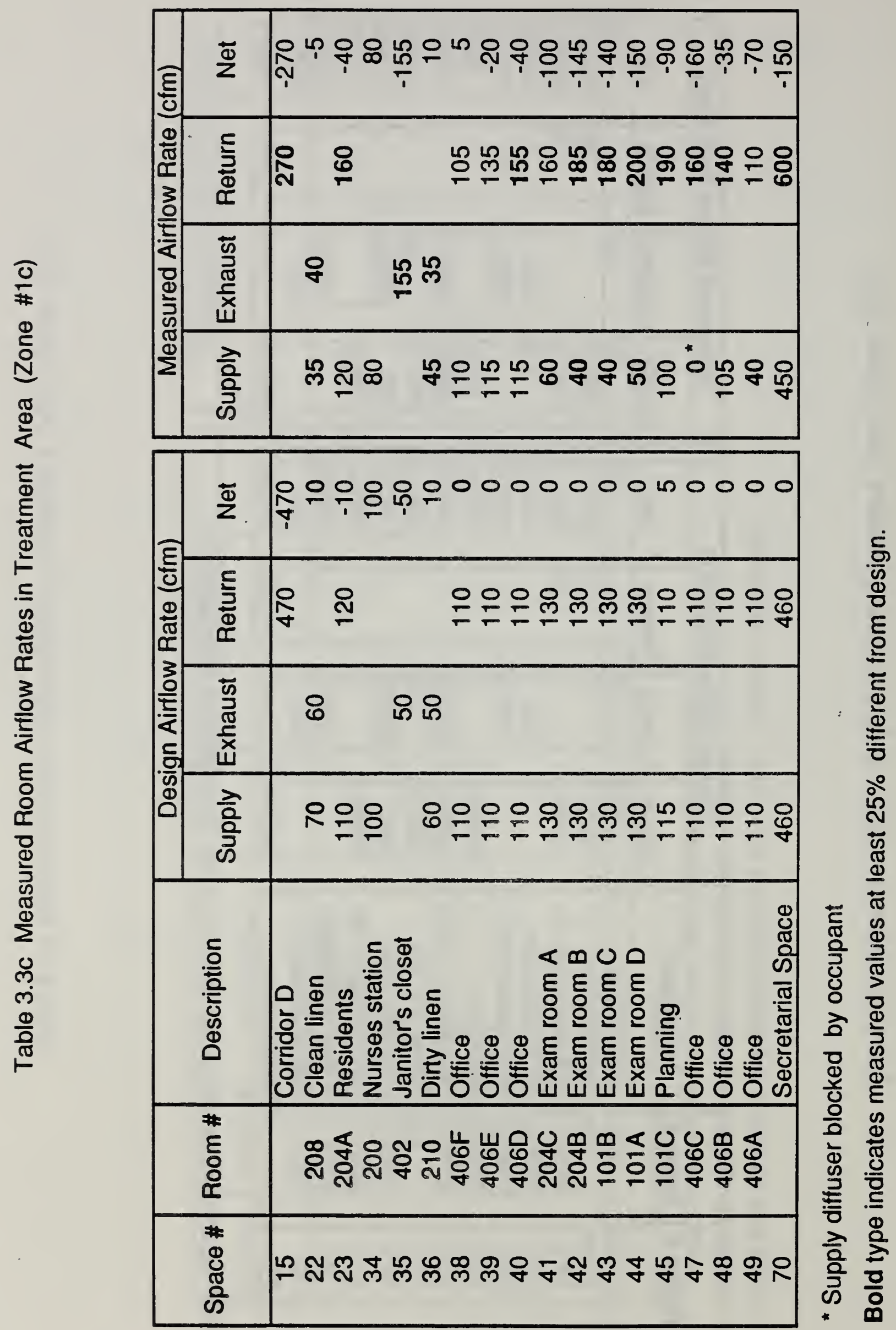




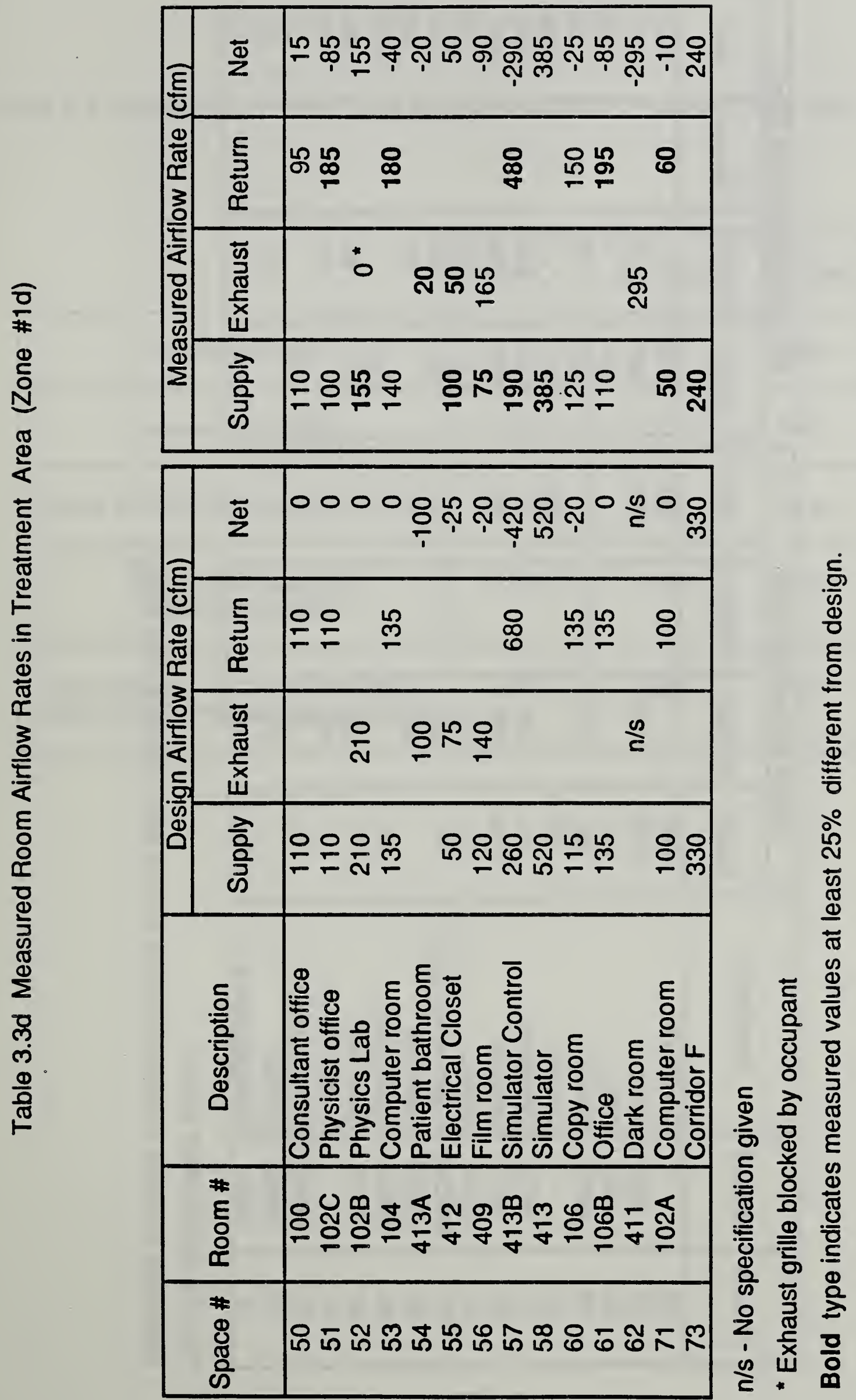




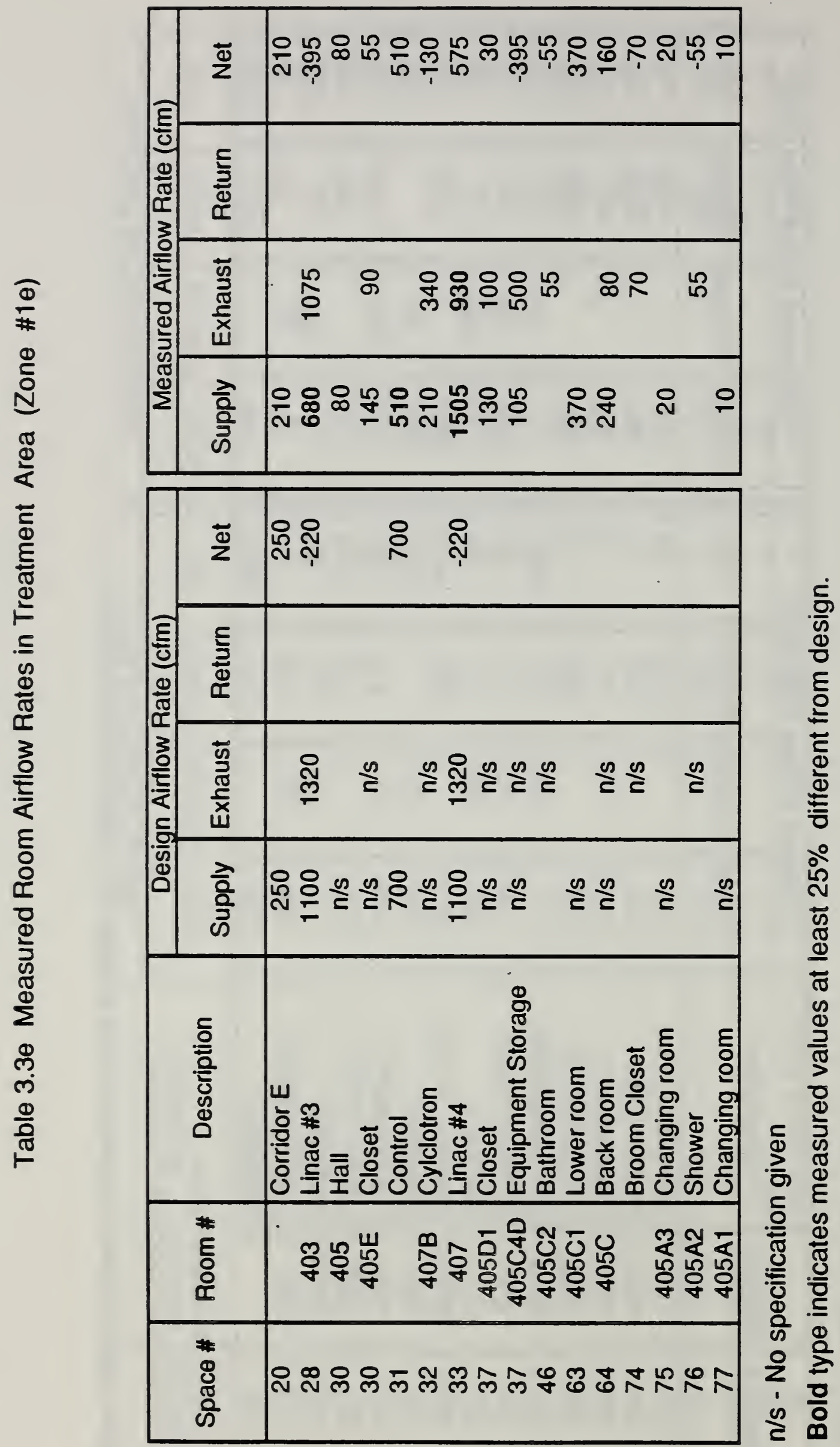


Table 3.4 Summary of Airflow Rate Measurements in Treatment Area (cfm)

\begin{tabular}{|c|c|c|c|}
\cline { 2 - 4 } \multicolumn{1}{c|}{ Fan Specifications } & SUPPLY & EXHAUST & RETURN \\
\hline Measured Fan Flows & 14,000 & 9,300 & 4,400 \\
\hline $\begin{array}{c}\text { Sum of all Measured Diffusers and Grilles } \\
\text { Sum of all Diffuser and } \\
\text { Grille Specifications }\end{array}$ & 10,930 & 6,710 & 4,245 \\
\hline $\begin{array}{c}\text { Sum of those Measured Airflow Rates } \\
\text { which have a Corresponding Specification }\end{array}$ & 9,555 & 4,000 & 5,800 \\
\hline
\end{tabular}


Table 3.5 System Airflow Rates for Zones \#2 and \#3

\begin{tabular}{|c|c|c|c|}
\hline \multicolumn{4}{|c|}{ SUPPLY } \\
\hline $\begin{array}{c}\text { DATE } \\
\text { MEASURED }\end{array}$ & TECHNIQUE & LOCATION & $\begin{array}{l}\text { AIRFLOW } \\
\text { RATE (cfm) }\end{array}$ \\
\hline $2 / 17 / 89$ & Hot - Wire & Roof & 13,700 \\
\hline 3/10/89 & Hot - Wire & $\begin{array}{c}\text { Mechanical } \\
\text { Room }\end{array}$ & 15,900 \\
\hline $3 / 20 / 89$ & Hot - Wire & Roof & 12,900 \\
\hline $4 / 7 / 89$ & Hot - Wire & Roof & 13,600 \\
\hline $4 / 7 / 89$ & Hot - Wire & $\begin{array}{c}\text { Mechanical } \\
\text { Room }\end{array}$ & 15,200 \\
\hline $4 / 7 / 89$ & $\begin{array}{c}\text { Tracer Gas } \\
\text { Pulse }\end{array}$ & - & 14,100 \\
\hline \multicolumn{3}{|l|}{ AVERAGE } & 14,200 \\
\hline \multicolumn{3}{|c|}{ DESIGN SPECIFICATION } & 11,000 \\
\hline \multicolumn{4}{|c|}{ EXHAUST } \\
\hline & & $\begin{array}{l}\text { MEASURED } \\
\text { AIRFLOW } \\
\text { RATE (cfm) }\end{array}$ & $\begin{array}{c}\text { DESIGN } \\
\text { AIRFLOW } \\
\text { RATE (cfm) }\end{array}$ \\
\hline EAST & & 3,300 & - \\
\hline WEST & & 2,770 & - \\
\hline TOTAL & & 6,070 & 5,105 \\
\hline
\end{tabular}




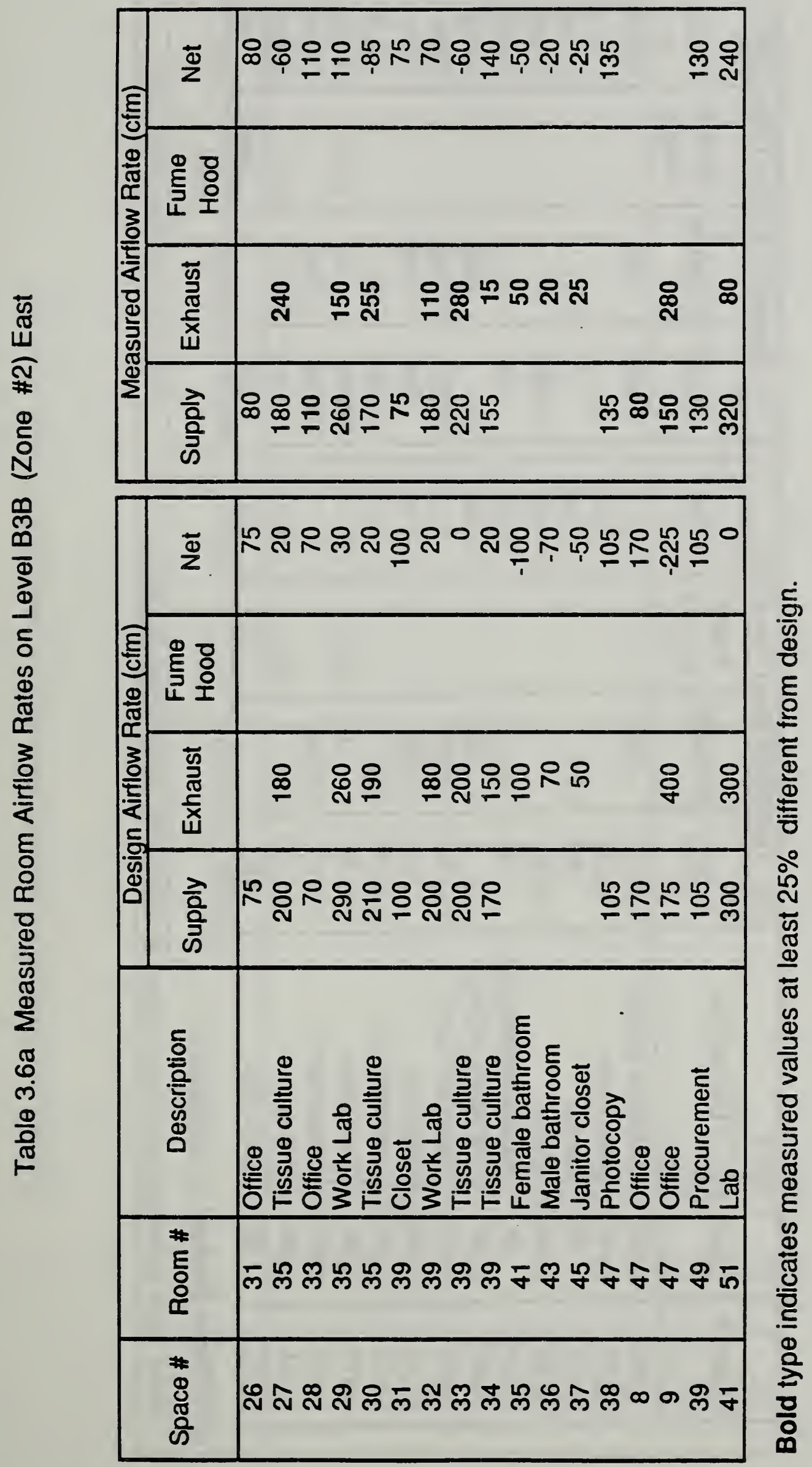




\begin{tabular}{|c|c|c|}
\hline 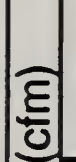 & $\bar{\Phi}$ & 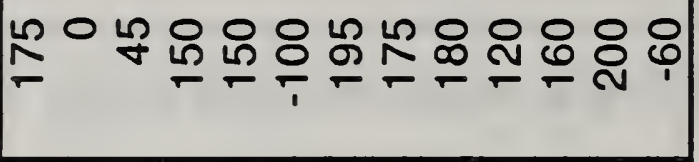 \\
\hline$\left|\begin{array}{l}\Phi \\
\frac{\pi}{20} \\
\frac{\pi}{3} \\
z \\
0\end{array}\right|$ & 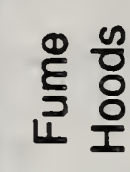 & : \\
\hline | & 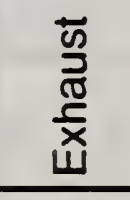 & 욜 윰용 욤 \\
\hline $\mid$ & के & 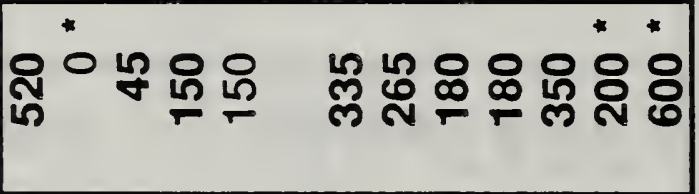 \\
\hline \multirow{4}{*}{ 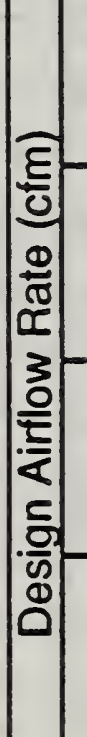 } & $\stackrel{\Phi}{z}$ & 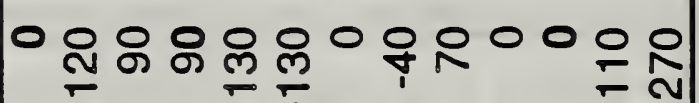 \\
\hline & 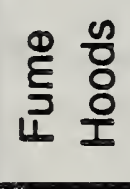 & \\
\hline & 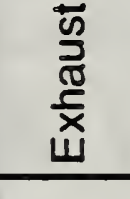 & ్ㅀㅇㅠ 윯 \\
\hline & ते & 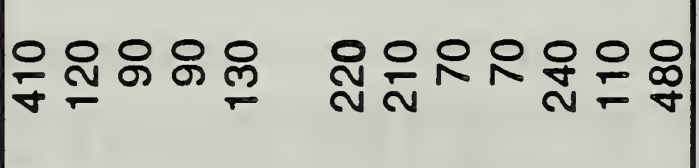 \\
\hline & 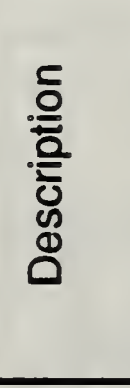 & 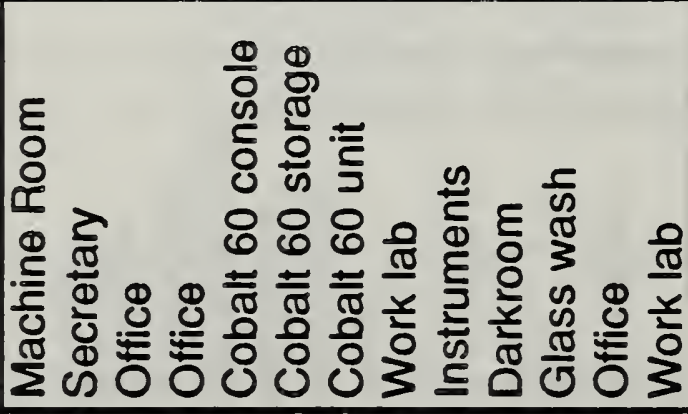 \\
\hline & 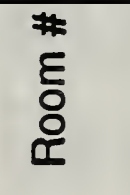 & 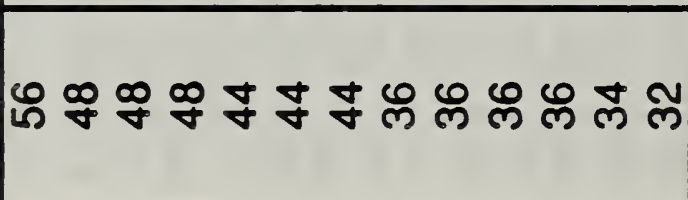 \\
\hline & $\begin{array}{l}\text { * } \\
\text { \& } \\
\text { ळू } \\
\text { की }\end{array}$ & 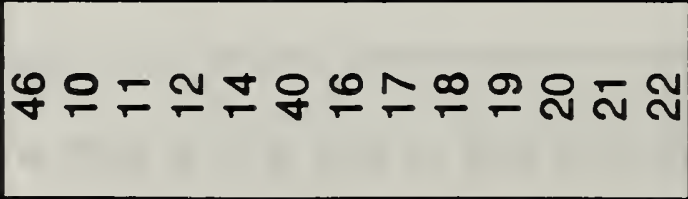 \\
\hline
\end{tabular}




\begin{tabular}{|c|c|c|}
\hline 氞 & $\stackrel{\mathbb{\Phi}}{z}$ & 虽 员品 \\
\hline$\left|\begin{array}{l}9 \\
\frac{9}{\pi} \\
\frac{\pi}{3} \\
\vdots \\
0\end{array}\right|$ & 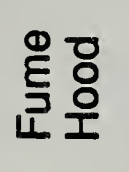 & 突 \\
\hline 蒄 & 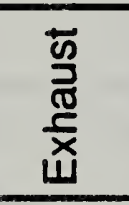 & 응오 $88 \%$ 유 웅 \\
\hline$\sum_{\infty}^{\infty}$ & के & 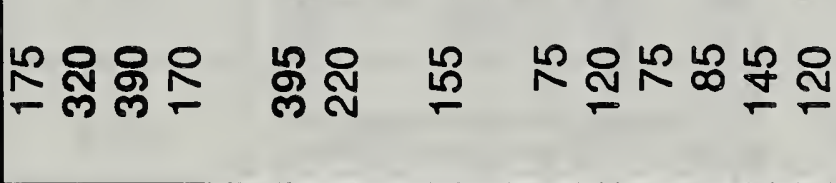 \\
\hline 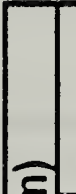 & $\frac{\Phi}{2}$ & 윤 \\
\hline $\mid$ & 害 & 只 \\
\hline 竧 & $\begin{array}{l}\bar{w} \\
\stackrel{\tilde{m}}{\tilde{m}} \\
\stackrel{x}{x} \\
\end{array}$ & 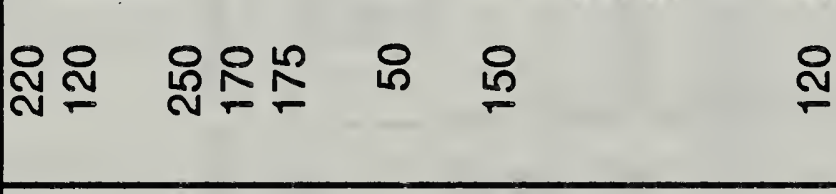 \\
\hline $\mid$ & के & 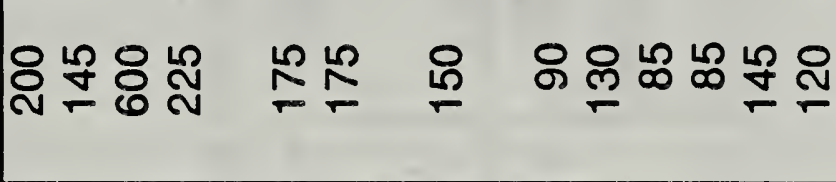 \\
\hline & 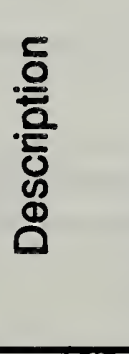 & 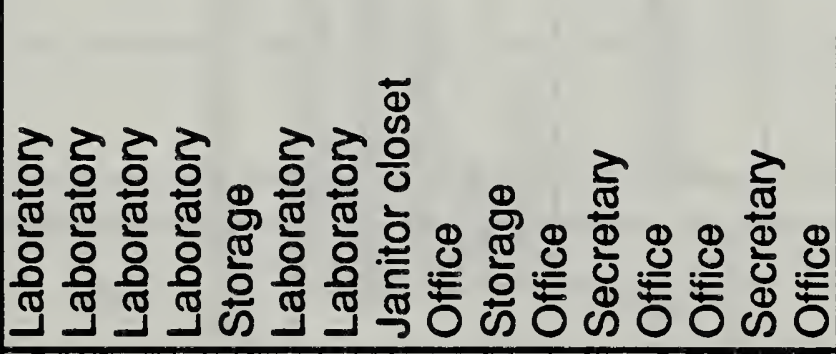 \\
\hline & 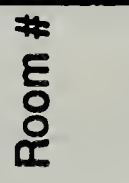 & 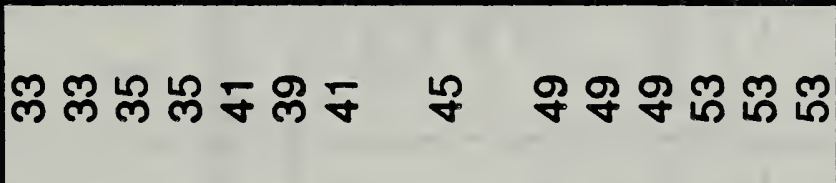 \\
\hline & $\begin{array}{l}\text { \# } \\
\text { \&ूँ } \\
\text { वू. } \\
\text { की }\end{array}$ & 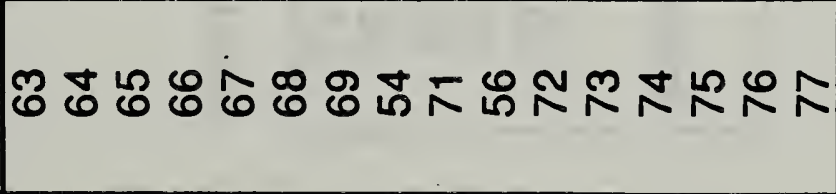 \\
\hline
\end{tabular}




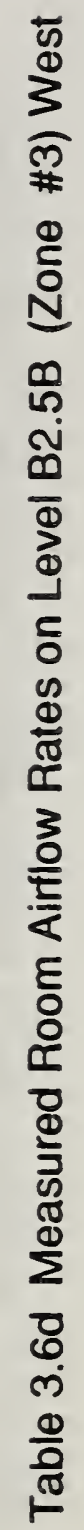
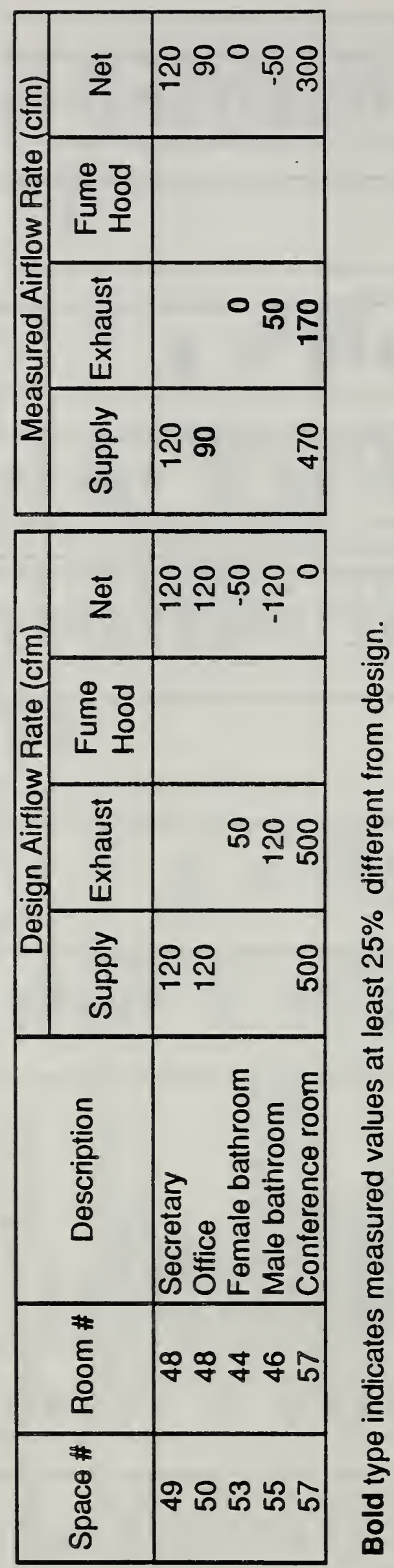
Table 3.7 Summary of Airflow Rate Measurements on Levels B3B and B2.5B

\begin{tabular}{|c|c|c|c|c|c|}
\hline & \multirow{2}{*}{\multicolumn{2}{|c|}{ B3B }} & \multirow{2}{*}{\multicolumn{2}{|c|}{$\mathrm{B} 2.5 \mathrm{~B}$}} & \multirow{4}{*}{ TOTAL } \\
\hline & & & & & \\
\hline & EAST & WEST & EAST & WEST & \\
\hline \multicolumn{5}{|l|}{ SUPPLY } & \\
\hline Sum of all specified airflow rates & 2,370 & 2,240 & 2,325 & 740 & 7,675 \\
\hline \multirow[t]{2}{*}{ Sum of all measured airflow rates } & 2,245 & 2,975 & 2,445 & 680 & 8,345 \\
\hline & 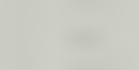 & \multicolumn{3}{|c|}{ AVERAGE FAN MEASUREMEN] } & 14,200 \\
\hline \multicolumn{6}{|l|}{ EXHAUST } \\
\hline Sum of all specified airflow rates & 2,080 & 1,320 & 1,255 & 670 & 5,325 \\
\hline \multirow[t]{2}{*}{ Sum of all measured airflow rates } & 1,505 & 925 & 1,045 & 220 & 3,695 \\
\hline & & \multicolumn{3}{|c|}{ DUCT MEASUREMENT } & 6,070 \\
\hline \multicolumn{6}{|l|}{ FUME HOODS } \\
\hline Sum of all specified airflow rates & - & 750 & 1,500 & - & 2,250 \\
\hline Sum of all measured airflow rates & - & 660 & 1,370 & - & 2,030 \\
\hline
\end{tabular}

\section{NET AIRFLOW RATES}

Design Specifications

Sum of Measurements

\begin{tabular}{|c|c|c|c|}
\hline 290 & 170 & -430 & 70 \\
\hline 740 & 1,390 & 30 & 460 \\
\hline
\end{tabular}

100

2,620 
Table 3.8 Measured Room Airflow Rates on Level 1B (Zone \#4)

\begin{tabular}{|c|c|c|c|c|c|c|c|c|c|c|}
\hline \multirow[b]{2}{*}{ Space \# } & \multirow[b]{2}{*}{ Room \# } & \multirow[b]{2}{*}{ Description } & \multicolumn{4}{|c|}{ Design Airflow Rate (cfm) } & \multicolumn{4}{|c|}{ Measured Airflow Rate (cfm) } \\
\hline & & & Supply & Exhaust & $\begin{array}{l}\text { Fume } \\
\text { Hood }\end{array}$ & Net & Supply & Exhaust & $\begin{array}{l}\text { Fume } \\
\text { Hood }\end{array}$ & Net \\
\hline 1 & $53 \mathrm{C}$ & Office & 145 & 145 & & $\overline{0}$ & 70 & 25 & & 45 \\
\hline 2 & $53 B$ & Office & 165 & 165 & & 0 & 155 & 15 & & 140 \\
\hline 3 & $51 B$ & Office & 200 & 200 & & 0 & 175 & 105 & & 70 \\
\hline 4 & $53 \mathrm{~A}$ & Office & 125 & 125 & & 0 & 100 & 5 & & 95 \\
\hline 5 & $51 C$ & Office & 125 & 125 & & 0 & 110 & 55 & . & 55 \\
\hline 6 & $51 \mathrm{~A}$ & Office & 225 & 225 & & 0 & 120 & 115 & & 5 \\
\hline 7 & $47 \mathrm{C}$ & Office & 200 & 200 & & 0 & 155 & 90 & & 65 \\
\hline 8 & $47 B$ & Office & 200 & 200 & & 0 & 125 & 85 & & 40 \\
\hline 9 & 470 & Office & 125 & 125 & & 0 & 135 & 15 & & 120 \\
\hline 10 & $47 A$ & Office & 125 & 125 & & 0 & 135 & 105 & & 30 \\
\hline 11 & 45 & Laboratory & 350 & 150 & & 200 & 180 & 130 & & 50 \\
\hline 13 & 43 & Laboratory & 250 & 550 & & .300 & 165 & 545 & & -380 \\
\hline 14 & 418 & Janitor & & 50 & & -50 & & 50 & & .50 \\
\hline 15 & $41 C$ & Male bathroom & 100 & 200 & & .100 & 110 & 75 & & 35 \\
\hline 16 & $41 \mathrm{~A}$ & Female bathroom & & 150 & & .150 & & 60 & & .60 \\
\hline 17 & $37 A$ & Office & 250 & 250 & & 0 & 155 & 140 & & 15 \\
\hline 18 & 378 & Office & 125 & 125 & & 0 & 125 & 95 & & 30 \\
\hline 19 & 35 & Storage & 250 & 250 & & 0 & 250 & 115 & & 135 \\
\hline 20 & 58 & Laboratory & 550 & & 600 & .50 & 380 & & 510 & .130 \\
\hline 21 & 54 & Laboratory & 525 & 575 & & .50 & 640 & 35 & & 605 \\
\hline 22 & 52 & Mould Lab & 125 & 175 & & .50 & 260 & 20 & & 240 \\
\hline 23 & $46 / 50$ & Entry way & 225 & & & 225 & 105 & & & 105 \\
\hline 25 & $46 A$ & Radiation Lab & 235 & & 815 & .580 & 225 & & 0 & 225 \\
\hline 26 & 468 & Laboratory & 125 & & & 125 & 115 & & & 115 \\
\hline 27 & $50 \mathrm{~A}$ & Laboratory & 250 & & 750 & -500 & 235 & & 1200 & .965 \\
\hline 28 & 44 & Cylinder Storage & & 100 & & .100 & & 85 & & .85 \\
\hline 29 & $42 A$ & Laboratory & 100 & 150 & & .50 & 220 & 100 & & 120 \\
\hline 31 & $44 A$ & Laboratory & 225 & 225 & & 0 & 320 & 120 & & 200 \\
\hline 32 & $40 A$ & Laboratory & 150 & 150 & & 0 & 320 & 85 & & 235 \\
\hline $33+$ & 40 & Lab-Animal cages & 395 & $70+n / s$ & & & 445 & $100+\mathrm{N} / \mathrm{m}$ & & 345 \\
\hline $34+$ & $38 \mathrm{~A}$ & Lab-Animal cages & 75 & ns & & & $\mathrm{Nm}$ & $\mathrm{n} / \mathrm{m}$ & & \\
\hline $35+$ & 34 & Lab & & & & 0 & & & & 0 \\
\hline $36+$ & $34 A$ & Lab & 50 & 100 & & .50 & 85 & 0 : & & 85 \\
\hline $37+$ & $34 B$ & Lab & 50 & & & 50 & 105 & & & 105 \\
\hline $38+$ & $36 \mathrm{C}$ & $\mathrm{Lab}$ & 100 & 150 & & .50 & $0^{* *}$ & 100 & & -100 \\
\hline \multirow{2}{*}{\multicolumn{3}{|c|}{$\begin{array}{l}n / s \text { - No design specification given } \\
n / m \text { - Not measured }\end{array}$}} & \multirow{2}{*}{\multicolumn{3}{|c|}{$\begin{array}{l}\text { Sum of specified flows } \\
\text { which were measured }\end{array}$}} & & \multirow{2}{*}{\multicolumn{3}{|c|}{ Sum of all measured flows }} & \\
\hline & & & & & & & & & & \\
\hline \multicolumn{3}{|c|}{ - Exhaust blocked b/ occupant } & 6065 & 5055 & 2165 & & 5720 & 2370 & 1710 & \\
\hline \multicolumn{3}{|c|}{ - Supply does not exist } & & & & & & & & \\
\hline
\end{tabular}

Bold type indicates measured values at least $25 \%$ different from design. 


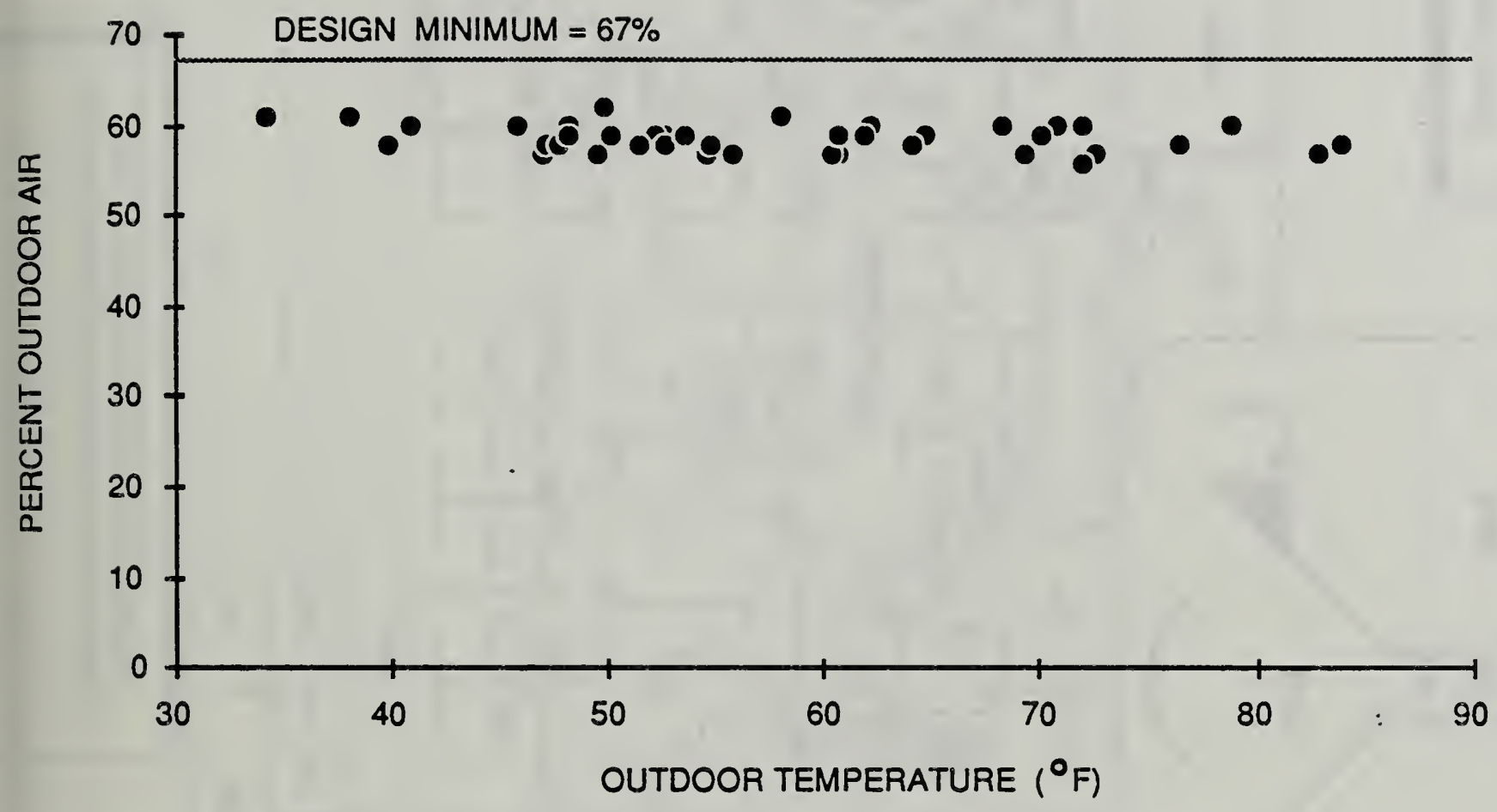

Figure 3.1 Percent Outdoor Air Intake vs. Outdoor Temperature 


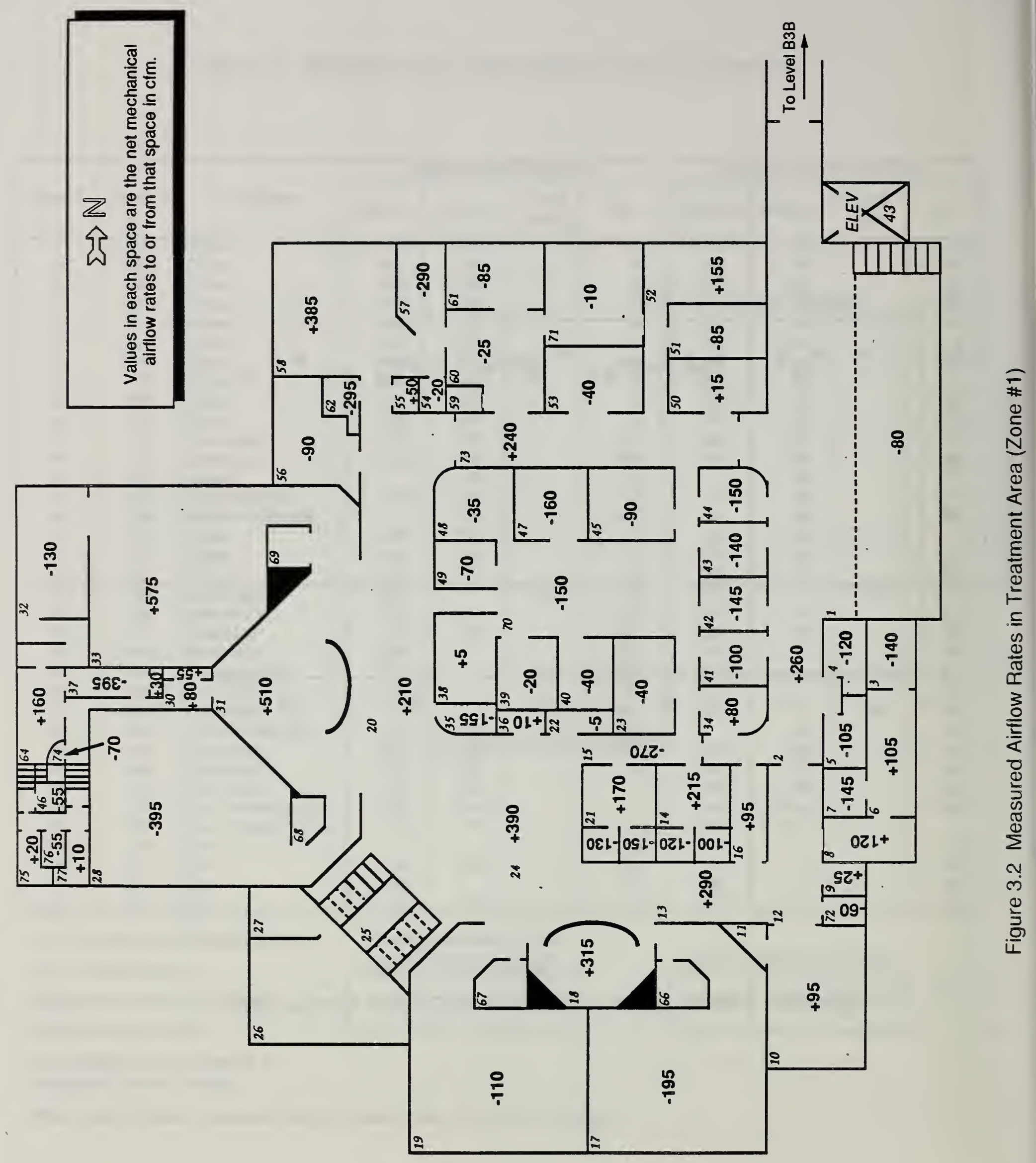




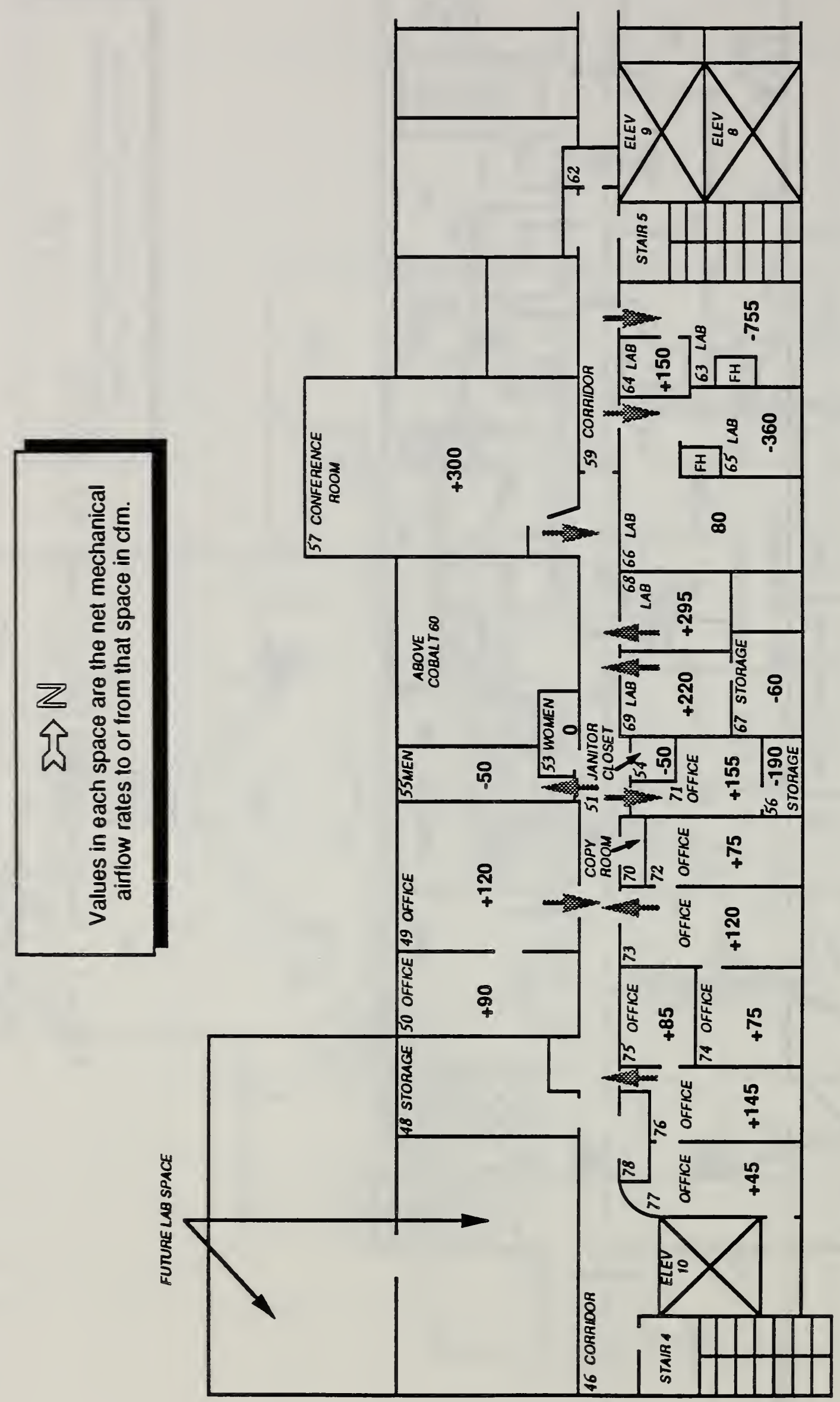




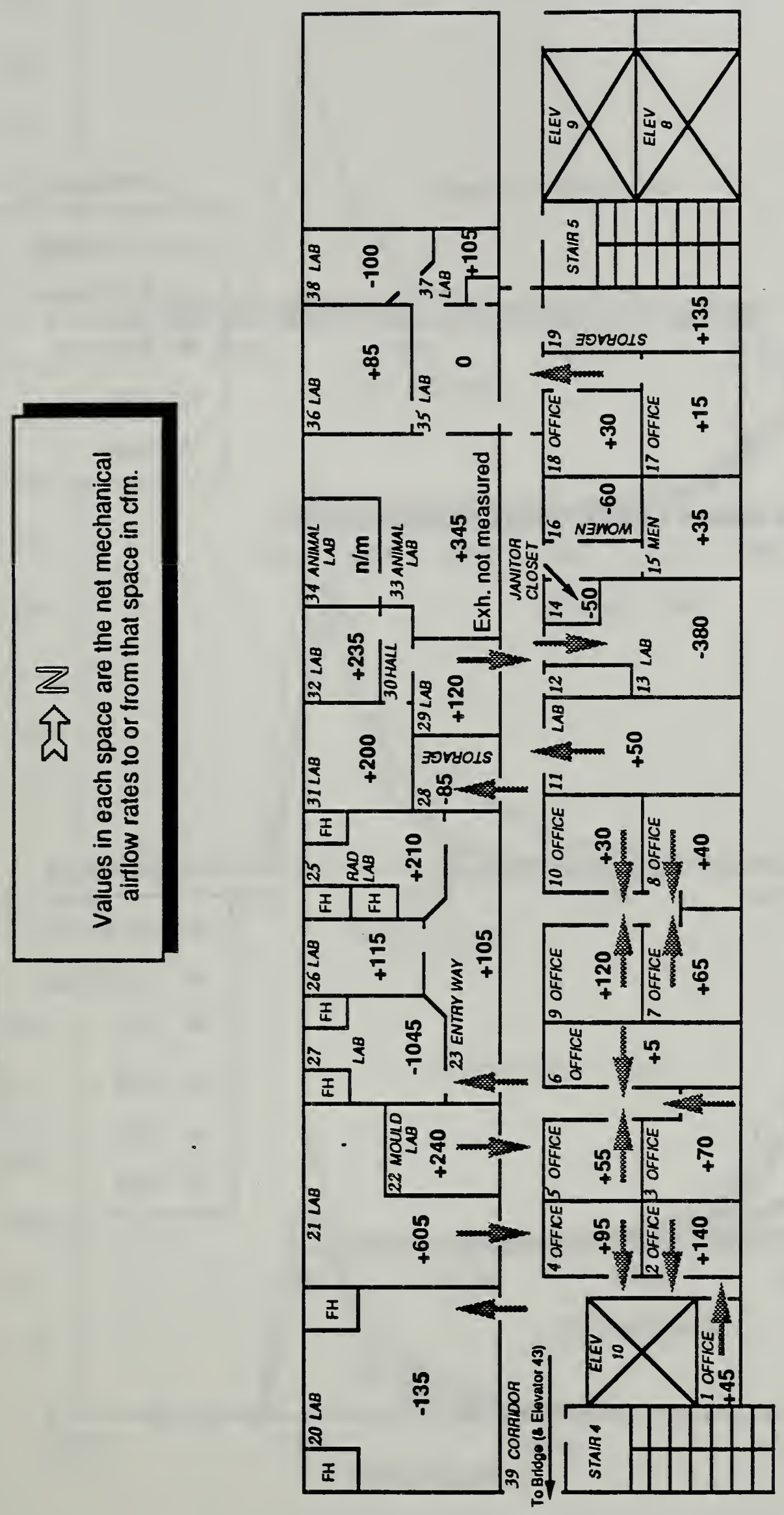

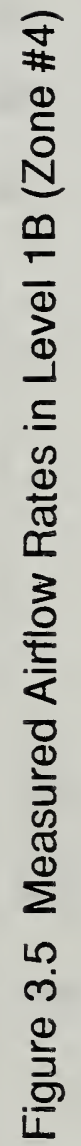



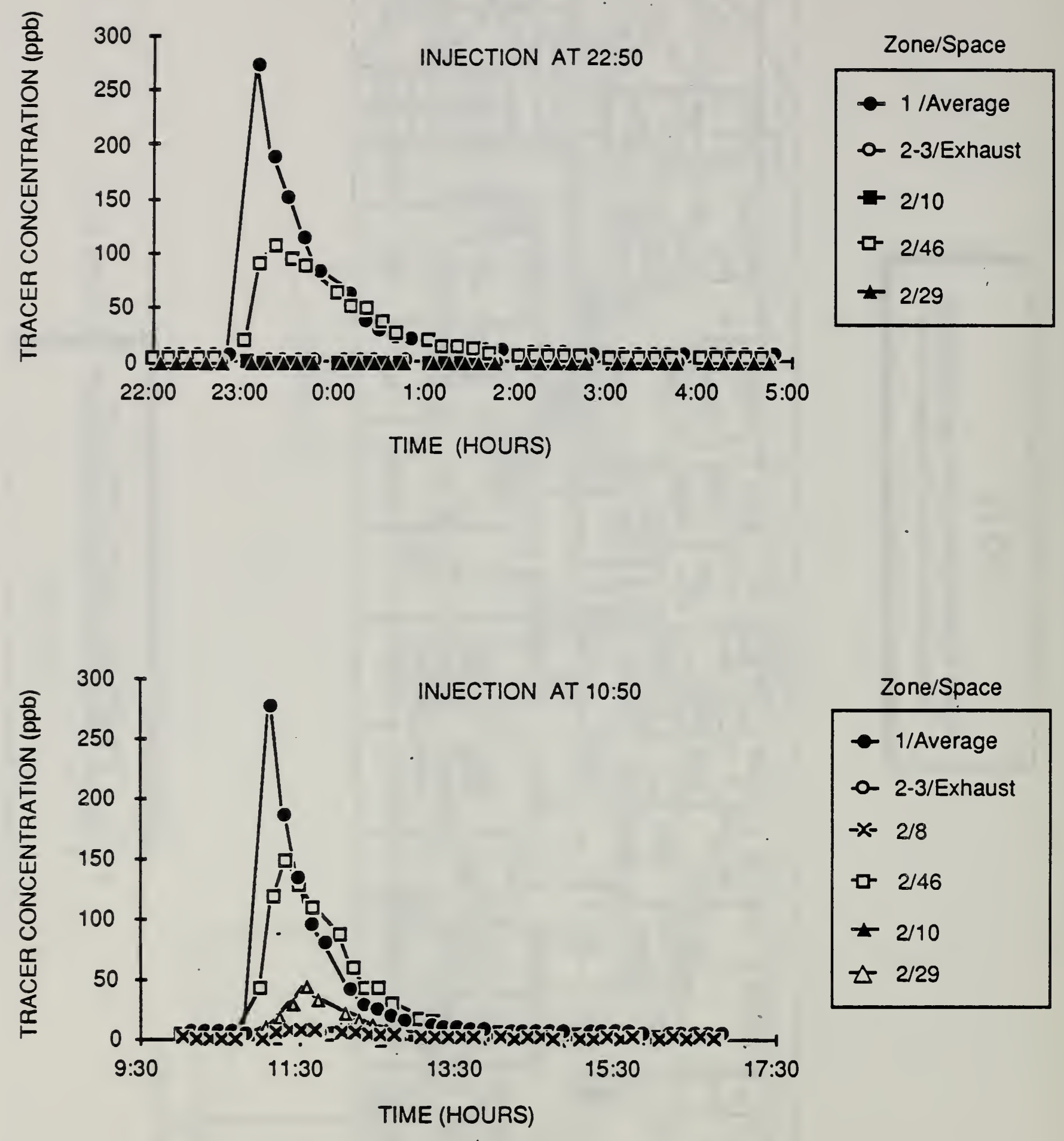

Figure 3.6 Tracer Gas Injection in Treatment Area 

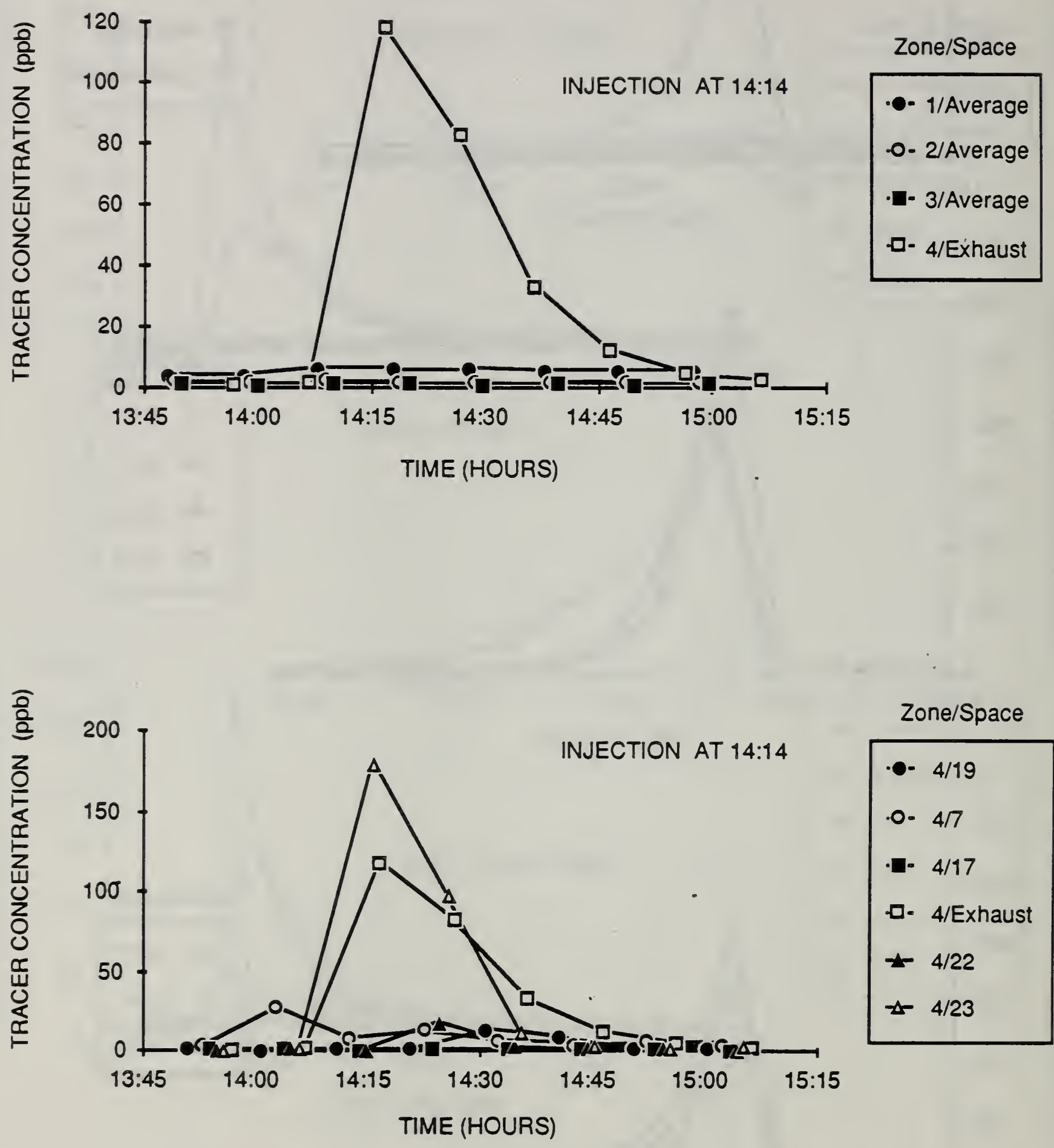

Zone/Space

$-04 / 19$
$0.4 / 7$
- $4 / 17$
ㅁ. $4 /$ Exhaust
$+4 / 22$
$-4 / 23$

Figure 3.8 Tracer Gas Injection in 1B Hallway 


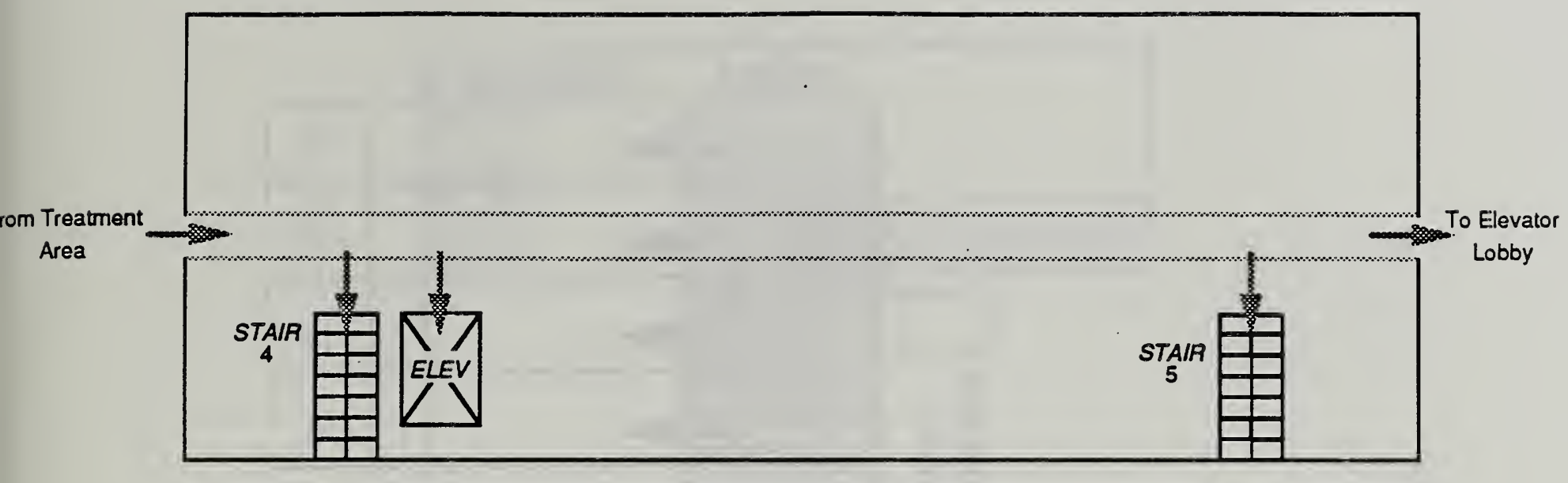

Level B3B (Zone 2)

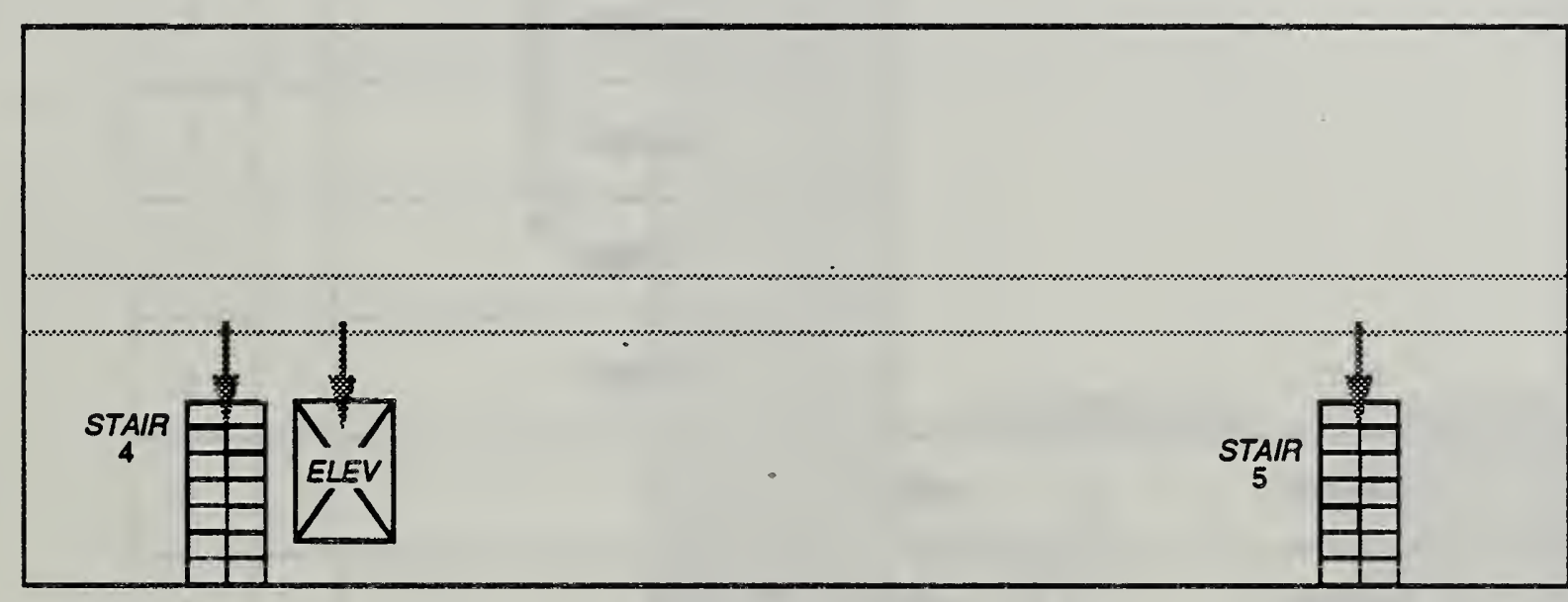

Level B2.5B (Zone 3)

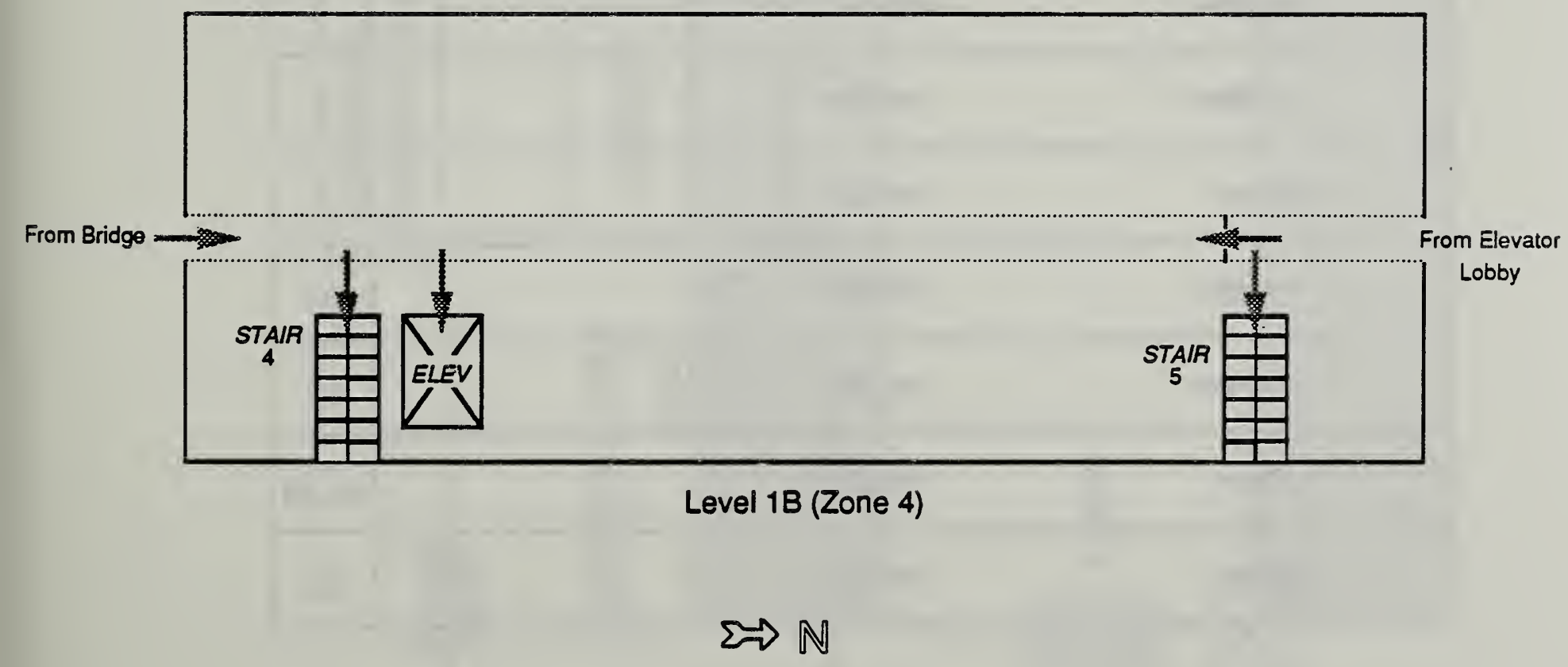

Figure 3.9 Air Flow Patterns from Smoke Tests 


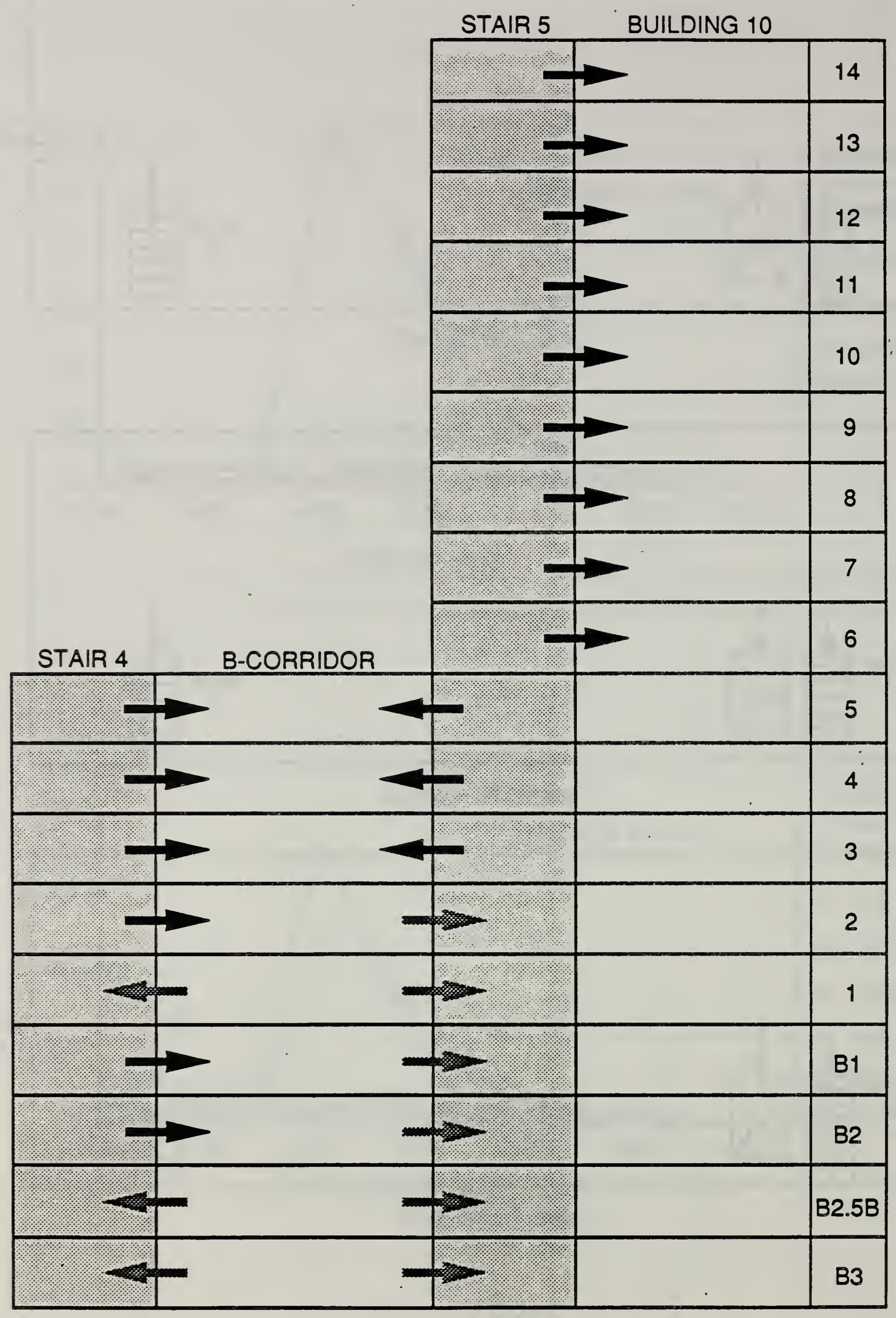

Figure 3.10 Results of Stairwell Smoke Tests 


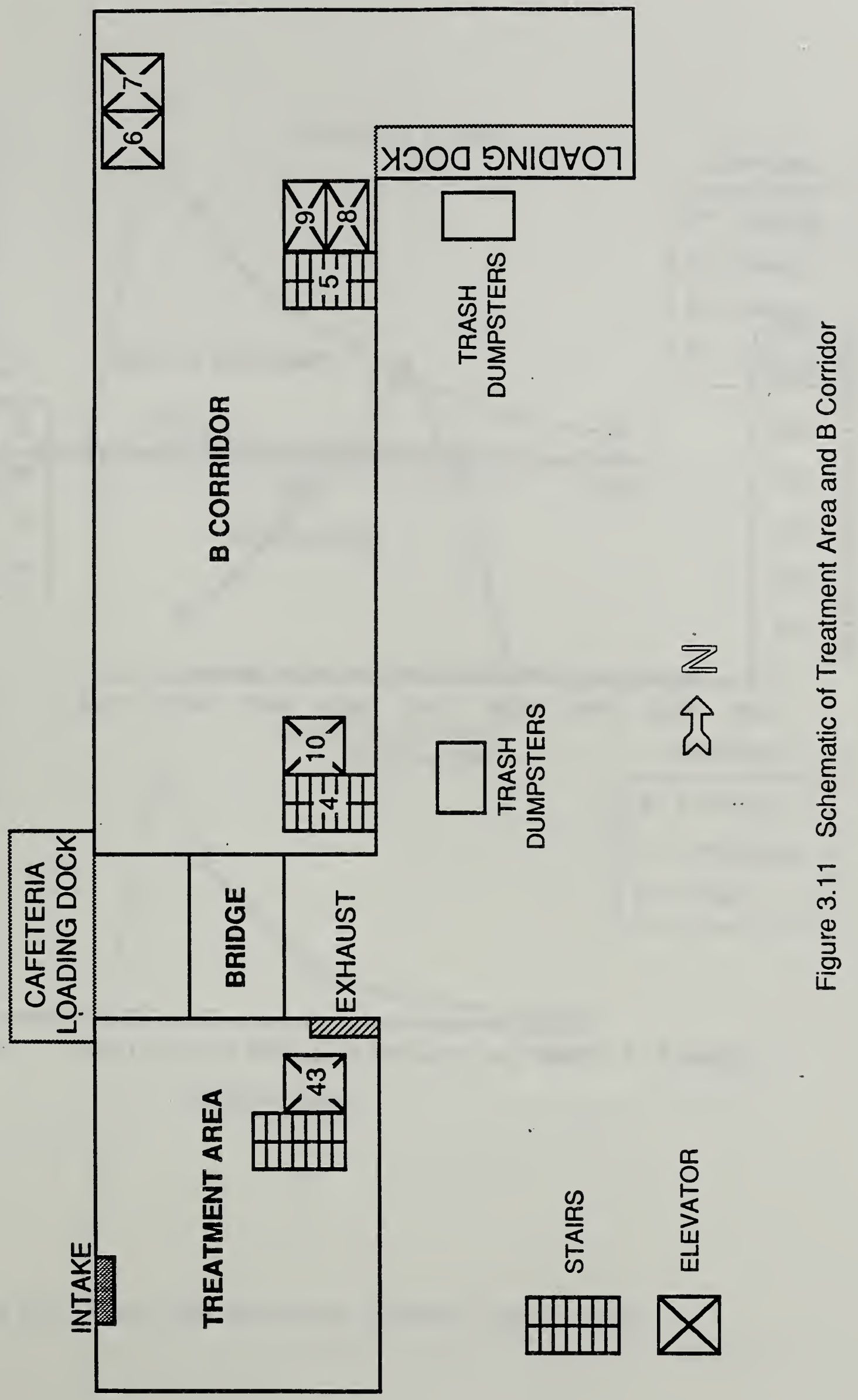




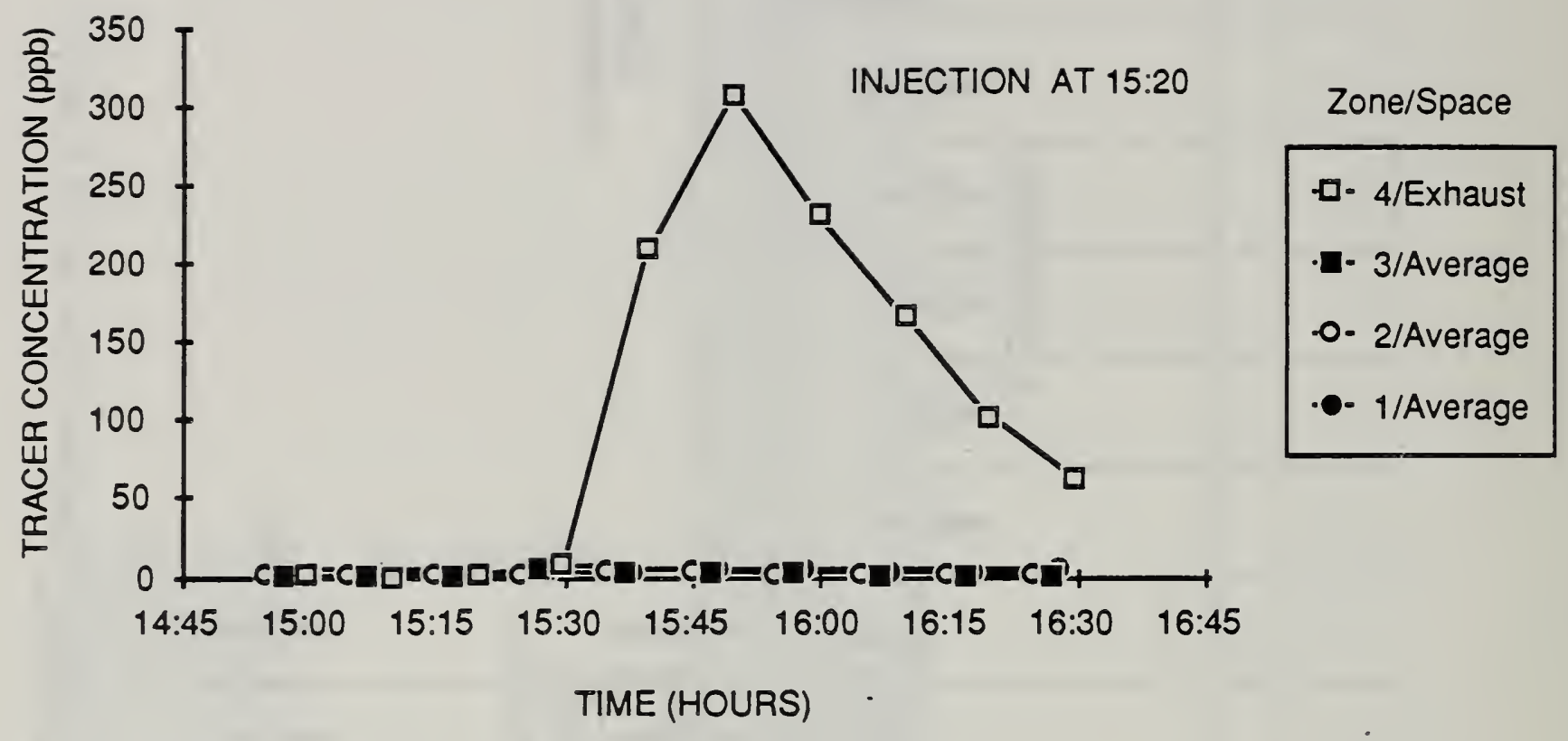

Figure 3.12 Tracer Gas Injection at Stair \#5 Loading Dock 

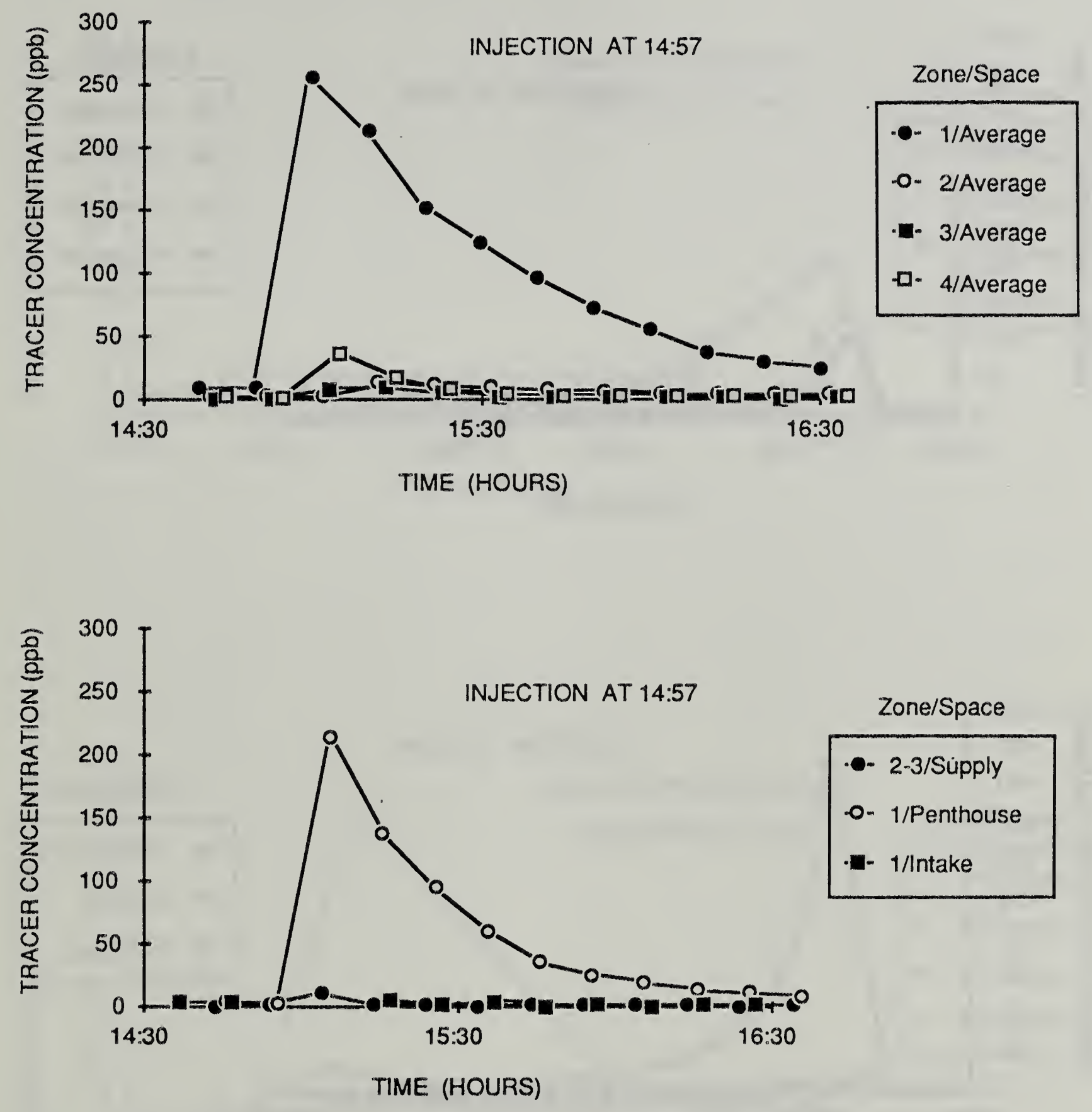

Figure 3.13 Tracer Gas Injection at Cafeteria Loading Dock 

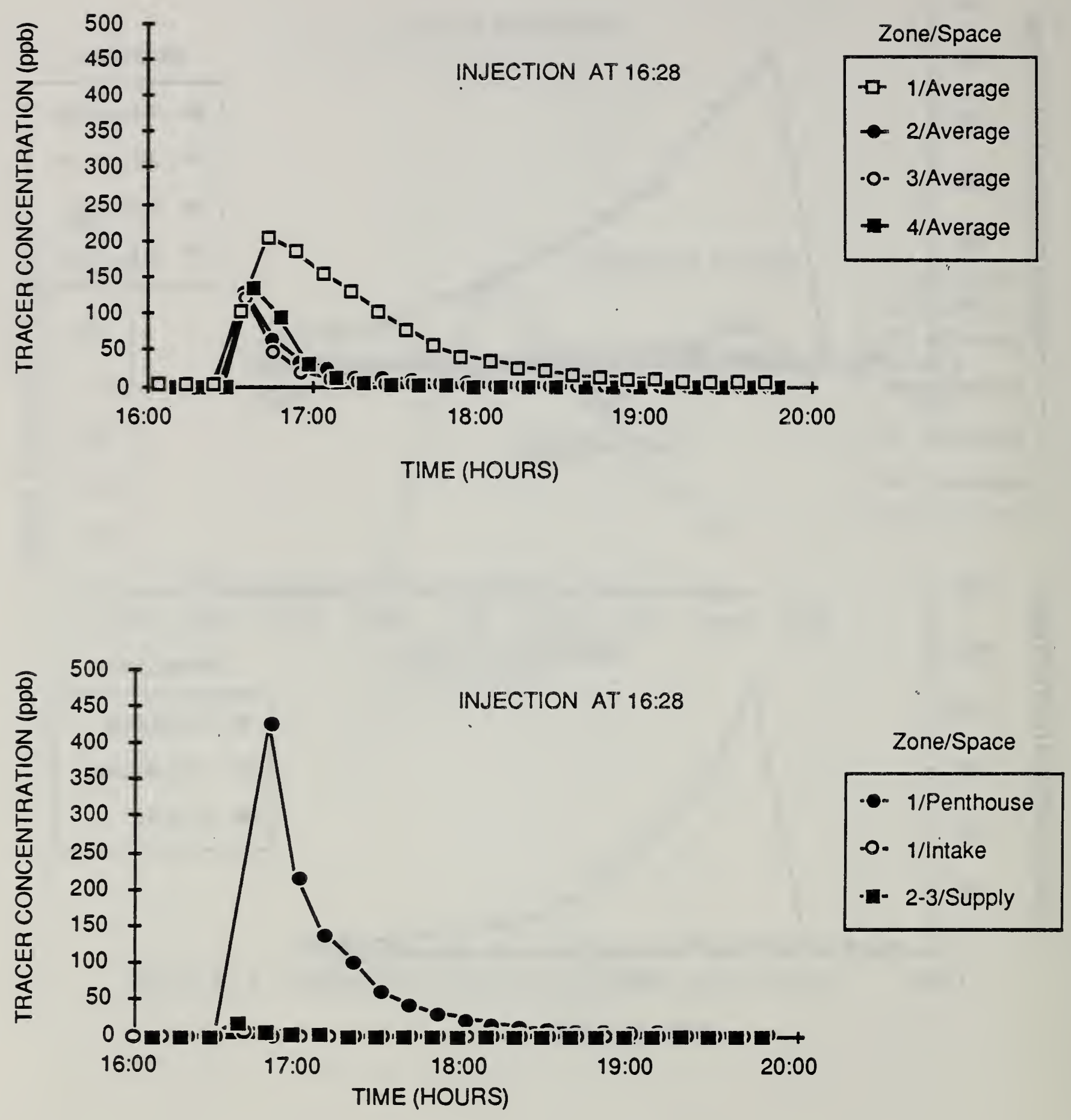

Figure 3.14 Tracer Gas Injection at Treatment Area Exhaust 


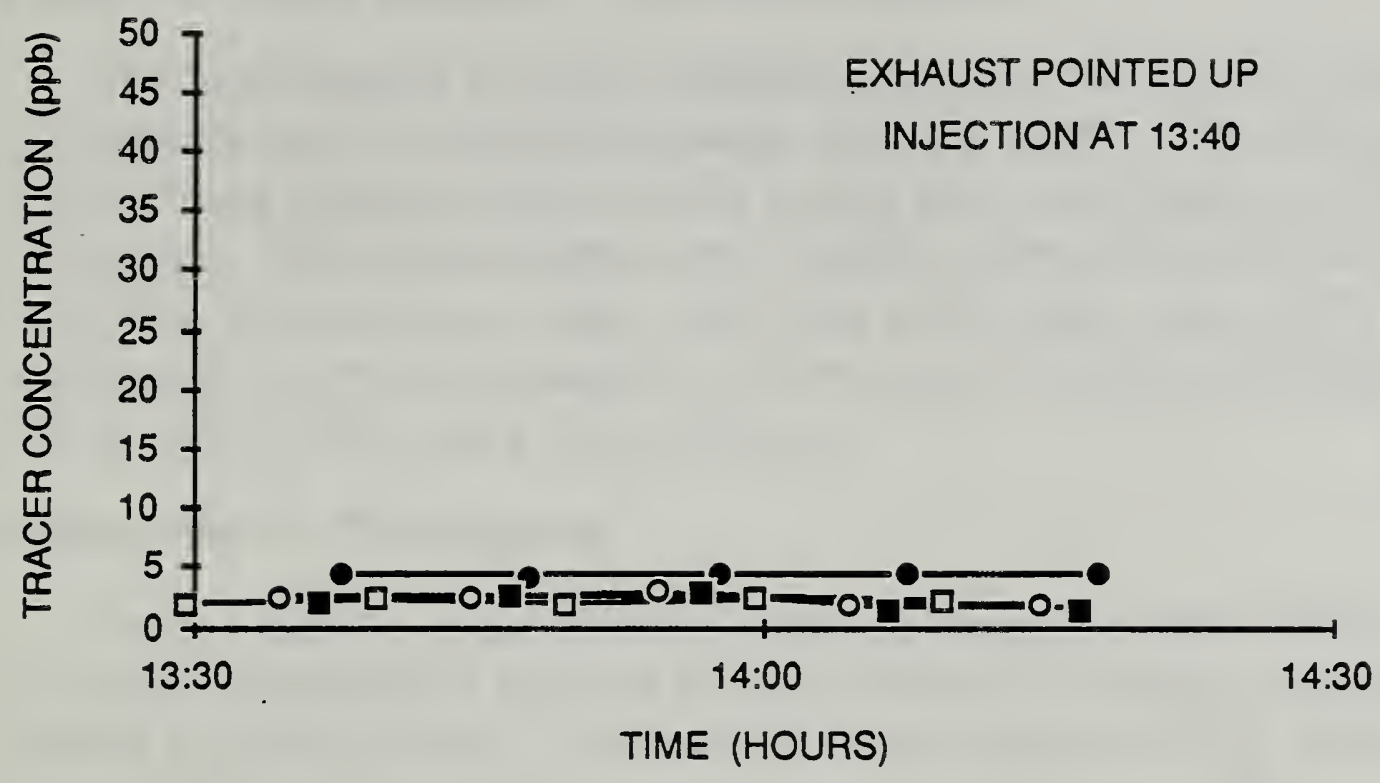

\section{Zone/Space}

- $1 /$ Average

- 2/Average

- 3/Average

ㅁ. 4/Exhaust

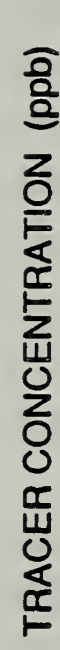

50
45
40
35
30
25
20
15
10
5
0

12:30
EXHAUST POINTED DOWN

INJECTION AT 12:40

\section{Zone/Space}

- 1/Average

- 2/Average

- 3/Average

ㅁ- 4/Exhaust

Figure 3.15 Tracer Gas Injection into B Corridor Exhaust 



\section{TASK 4: CONTAMINANT MEASUREMENTS}

The fourth task of the NIST evaluation of indoor air quality in the ROB involved the measurement of contaminant levels within the facility. The techniques used to perform these measurements and the results that were obtained are discussed in this section. The pollutants that were studied include carbon dioxide, carbon monoxide, formaldehyde, radon, respirable particulates, and volatile organic compounds. In order to evaluate the thermal comfort within the facility, temperature and relative humidity were also monitored.

\section{Measurement Procedures}

Carbon dioxide concentrations within buildings are often measured in indoor air quality investigations because of their relation to the rate of ventilation relative to building occupancy levels. While indoor concentrations of $\mathrm{CO}_{2}$ rarely reach levels of concern within buildings, they are thought to provide an indicator of the adequacy of outdoor air ventilation levels [Salisbury 1986]. Carbon dioxide levels were measured in the $\mathrm{ROB}$ facility to evaluate the adequacy of ventilation in the space, as a supplement to the airflow measurements discussed under Task 3 , and to compare the measured levels to guidelines for maximum $\mathrm{CO}_{2}$ concentrations. The measurements were made with an automated $\mathrm{CO}_{2}$ monitoring system that was integrated with the air sampling system described in Task 3 . The monitoring system employs an infrared absorption analyzer for determining $\mathrm{CO}_{2}$ concentrations and a microcomputer to switch among the sampling locations and record the data. $\mathrm{CO}_{2}$ concentrations were monitored at ten locations with each location being monitored once every ten minutes. The ten sampling locations consisted of selected combinations of the air sample locations listed in Table 3.1. The $\mathrm{CO}_{2}$ monitor has a range of 0 to 2500 parts per million (ppm) and is accurate to within $+1-0.5 \%$ of full scale.

Carbon monoxide was measured to determine whether the air within the building was being contaminated by automobile and truck exhaust from the loading docks or by other sources of $\mathrm{CO}$. There have been complaints of odors within the building that could be associated with these sources, and $\mathrm{CO}$ was measured as a surrogate for these sources. CO concentrations were measured using a hand-held electrochemical monitor which is accurate to within $+/-2 \%$ of reading or $+/-2 \mathrm{ppm}$, whichever is greater. Sampling took place throughout all four zones by walking through the space with the monitor operating.

Formaldehyde in buildings has been associated with building materials such as particleboard, plywood, and adhesives and could be associated with some of the laboratory procedures occurring in this building. It can be irritating at 
concentrations of about $0.1 \mathrm{ppm}$, with large variations in the sensitivity among people. Formaldehyde concentrations were measured with passive monitors based on absorption onto a sodium-bisulfite treated filter and analysis by the chromotropic acid colorimetric method. These passive samplers yield average formaldehyde concentrations for periods from 5 to 7 days. Samplers were deployed at sixteen locations throughout all four zones and sent to an outside laboratory for analysis.

It is clear that radon could not be a cause of indoor air quality complaints due to the fact that it is a odorless and nonirritating gas. However, due to general concerns about indoor radon, radon levels were measured in the ROB facility. Radon gas enters buildings primarily from the ground and has generally not been thought to be a problem in mechanically ventilated nonresidential buildings, although only a small number of such buildings have actually been monitored. Radon concentrations were measured at fifteen locations within the four zones with charcoal canisters for a three day test period, and the canisters were sent to an outside laboratory for analysis. The measurement technique is accurate to within about $20 \%$, and the minimum detectable concentration is $0.4 \mathrm{pCi} / \mathrm{L}$.

Particulate levels were monitored in the facility using two techniques, a lightscattering particle counter and a respirable aerosol mass monitor. There are numerous and varied sources of particles both within and outside of this and any building, including trash dumpsters, building renovation work, motor vehicle exhaust, smoking, and the ambient air. Elevated particle concentrations are both a health and comfort concern, with these effects depending on the concentration, size and composition of the particles. The light-scattering particle counter determines particle concentrations (number of particles per $\mathrm{m}^{3}$ of air) in six different particulate diameter size ranges $(0.3-0.5,0.5-0.7,0.7-1.0,1-5,5-10$, and $>10 \mu \mathrm{m})$. The respirable aerosol mass monitor determines the mass of airborne particles per $\mathrm{m}^{3}$ of air and is based on a piezoelectric microbalance sensor. Ideally, the mass monitor weighs all of the particles smaller than a selected aerodynamic cutoff diameter $(3.5 \mu \mathrm{m}$ in this case) and yields a measure of particle mass per unit volume $\left(\mu \mathrm{g} / \mathrm{m}^{3}\right)$. While the measured particle concentrations and mass levels do not provide information on the composition of the particulate matter, high readings are indicative of poor air quality. The light-scattering particle counter operates in real-time, sampling from one location at a time, with the data recorded on a personal computer-based data acquisition system. The system was deployed in three locations in the facility for periods of several days each: the Treatment Area lobby, the Treatment Area simulator control room (Space 58), and room B2.5B53 (Space 77). The particulate mass monitor is operated by hand with data recorded by the operator, and each measurement requires only a few minutes. The mass 
monitor measurements were made at several locations throughout the facility.

The levels of volatile organic compounds (VOC) were measured using active sampling on a sorbent trap and analysis with a gas chromatograph coupled to a mass spectrometer. The measurement equipment included an air sampling system for exposing the traps, a thermal desorber to transport the sample from the traps to the gas chromatograph, and the gas chromatograph and the mass spectrometer for analyzing the samples. The air sampling system consisted of constant flow pumps equipped with tubing and fittings for the attachment of the air sampling traps. Samples were collected on multibed, graphetized carbon black sorbent traps by drawing 0.5 to $3.0 \mathrm{~L}$ of air over the traps using the air sample pumps at a nominal flow rate of $100 \mathrm{ml} / \mathrm{min}$ for sampling periods from 5 to 30 minutes. The exposed traps were then transported back to NIST for analysis. The traps were analyzed by thermally desorbing the compounds from each trap into a capillary gas chromatograph interfaced with a mass selective detector (MSD), i.e., a mass spectrometer. The MSD was operated in scan mode to perform qualitative analysis and in selected ion mode to perform quantitative analysis. The qualitative analysis procedures were used to identify the compounds in the sample based on a library search of accumulated mass spectra and matching retention times of standards. The quantitative procedures provided the mass per unit volume $(\mu \mathrm{g} / \mathrm{m} 3)$ of each VOC in the sample based on a comparison against standard samples. VOC measurements were made in the Treatment Area exhaust and return ducts, the east and west exhaust ducts for Levels $B 3 B$ and $B 2.5 B$, and in the Level $1 B$ exhaust duct.

Many of the occupant complaints in the ROB facility can be characterized as thermal comfort complaints, e.g., too hot, too cold, dry air, stuffiness. Thermal comfort is dependent upon temperature, relative humidity $(\mathrm{RH})$ and air velocity, with large variations among individuals with regards to acceptable ranges for these parameters. As an indication of thermal comfort, temperature and relative humidity were measured with a hand-held device equipped with a resistance temperature detector (RTD) and a thin-film humidity sensor. The temperature and relative humidity measurements are accurate to within about $2 \%$. Measurements were taken throughout the $\mathrm{ROB}$ facility on several different occasions. 


\section{Results and Discussion}

Indoor levels of carbon dioxide, carbon monoxide, formaldehyde, radon, particulates and VOCs were measured in the ROB facility using the techniques described above. The results of these measurements are presented in this section and discussed with reference to current standards and guidelines. During all of the contaminant measurements, the mechanical ventilation systems serving the ROB were operating normally, i.e., twenty-four hours a day with a minimum amount of outdoor air intake in the Treatment Area and 100\% outdoor air intake on Levels $\mathrm{B} 3 \mathrm{~B}, \mathrm{~B} 2.5 \mathrm{~B}$ and $1 \mathrm{~B}$.

Long-term, automated measurements of $\mathrm{CO}_{2}$ levels were made throughout the ROB facility, and the results are summarized in Table 4.1. This table lists the means, standard deviations and maximums of the daily peak $\mathrm{CO}_{2}$ levels for the major zones of the ROB, as well as the means and maximums for several individual rooms within each zone. An example of typical, daily patterns in $\mathrm{CO}_{2}$ concentration is shown in Figure 4:1, in which the average of the $\mathrm{CO}_{2}$ concentrations in the Treatment Area exhaust and return ducts and the outdoor concentration are plotted against time for a period of five days. On a typical working day, the indoor $\mathrm{CO}_{2}$ concentration starts the day close to the outdoor concentration and increases when people begin entering the building. The concentration peaks during midmorning, after the occupancy level has stabilized. The concentration decreases during the lunch hour and increases again in the afternoon. After the occupants leave the building, the $\mathrm{CO}_{2}$ level decreases to essentially the outdoor concentration, with a slight elevation above outdoors due to constant, yet small, indoor sources of $\mathrm{CO}_{2}$. During the weekend, when building occupancy levels are very low, the indoor concentration essentially tracks the outdoor concentration, with a slight elevation above the outdoor concentration. The pattern in Figure 4.1 is fairly typical for a building that is occupied only during working hours.

Table 4.1 presents information on the peak values of $\mathrm{CO}_{2}$ in the building on working days. The table lists daily peak values of hourly average concentrations for the Zone \#1 (Treatment Area) return and exhaust ducts, the exhaust duct for Zones \#2 and \#3, and the Zone \#4 exhaust, followed by the peak concentrations within individual rooms. These daily peak values are affected by the occupancy levels, ventilation rates, and the outdoor concentrations, which are normally around $350 \mathrm{ppm}$ but can be above $400 \mathrm{ppm}$. The average peak concentration in the facility is between about 450 and 500 ppm, with somewhat higher levels in Zone \#4. ASHRAE Standard 62-1981 [ASHRAE 1981] provides a recommendation for maximum indoor $\mathrm{CO}_{2}$ levels of $2500 \mathrm{ppm}$. The revised version of this standard (expected to be published in 1989) will reduce this recommended maximum to 
$1000 \mathrm{ppm}$. The maximum values for each zone are well within these limits, indicating that these spaces as a whole are well ventilated relative to the occupancy levels according to the ASHRAE standard.

Table 4.1 also presents mean and maximum values of daily peaks for individual rooms. These values exhibit more variation and higher values than the zone exhausts. While none of the room measurements exceed the ASHRAE levels, there are several rooms with relatively high $\mathrm{CO}_{2}$ levels. The nurses station in Zone \#1 (Space 34) has an average daily peak above 600 ppm. Two rooms, an office in Zone \#2 (Space 8) and the conference room in Zone \#3 (Space 57), have a maximum daily peak above $800 \mathrm{ppm}$. These elevated room concentrations indicate that the ventilation rates for these spaces, in relation to their occupancy levels, are relatively low as compared with the rest of the ROB. The magnitude of the measured peaks are consistent with the number of occupants in the rooms and the measured ventilation rates.

Carbon monoxide levels in the ROB facility were measured with a hand-held monitor and found to be very low. The measured $\mathrm{CO}$ levels were about $1 \mathrm{ppm}$ at all locations during the monitoring periods, which is close to the minimum detectable limit of the monitor. ASHRAE Standard 62-1981 bases its acceptable level for indoor $\mathrm{CO}$ concentrations on the outdoor air requirements in the National Ambient Air Quality Standards [U.S. Environmental Protection Agency] i.e., maximum average $C O$ concentrations of $35 \mathrm{ppm}$ for one hour and $9 \mathrm{ppm}$ for 8 hours. The 1989 revision of the ASHRAE standard reports that concentrations above $10 \mathrm{ppm}$ have been suggested as being of limited concern. The measured $\mathrm{CO}$ levels in the ROB facility were very low compared to these levels. However, since the migration of motor vehicle exhaust into the building is an inherently episodic phenomena (depending on weather and fan operations conditions), it is possible that the $\mathrm{CO}$ levels are higher at other times than they were when we were monitoring $\mathrm{CO}$. Therefore, the low levels of $\mathrm{CO}$ measured in the facility are not inconsistent with the motor vehicle exhaust odors occasionally reported by the occupants.

The results of the formaldehyde concentration measurements in the ROB facility are presented in Table 4.2. These measurements were obtained with passive monitors that were deployed at the locations listed for approximately one week in February 1989. All of the measured values are very low, 0.01 to $0.02 \mathrm{ppm}$. ASHRAE Standard 62-1981 contains a guideline for formaldehyde concentrations not to exceed $0.1 \mathrm{ppm}$, based on continuous exposure. The 1989 revision of this standard contains no such guideline, but instead reports that concentrations above $0.1 \mathrm{ppm}$ have been recognized as a level of concern. The measured formaldehyde levels in the ROB are an order of magnitude below the ASHRAE recommendation and are therefore not an air quality issue based on this standard. 
Table 4.3 presents the results of the radon measurements in the ROB facility. These measurements were made with charcoal canisters deployed for about three days. Even though most of the ROB facility is below grade, all of the measured radon levels were less than $0.4 \mathrm{pCi} / \mathrm{L}$, the minimum detectable concentration of the canisters. These low levels are particularly interesting given the fact, discussed in Task 3 , that the lower levels of the B corridor are at a negative pressure relative to the rest of the building. Such a situation will generally cause increased radon entry rates into a building, leading to the potential for high concentrations. ASHRAE Standard 62-1981 provides a guideline concentration for radon decay products of 0.01 Working Levels, which converts to a radon concentration of approximately 2.5 $\mathrm{pCi} / \mathrm{L}$. The 1989 revision contains a guideline concentration of about $7 \mathrm{pCi} / \mathrm{L}$. The U.S. Environmental Protection Agency has an "action level" for radon of $4 \mathrm{pCi} / \mathrm{L}$, meaning that action should be taken in a building with concentrations above 4 $\mathrm{pCi} / \mathrm{L}$ to reduce these concentrations. The measured radon concentrations in the $\mathrm{ROB}$ were all well below both of these recommendations.

Respirable particulate levels in the ROB were measured with a light-scattering particle counter that determines particle concentrations and with a respirable aerosol mass monitor that measures the mass of particulate matter in the air. Figure 4.2 shows an example of particulate concentration data measured in the Treatment Area reception area over one week for all six particulate diameter size ranges. These data are similar to those seen in other buildings in that the variation in the concentrations of the larger particles ( $>5 \mu \mathrm{m}$ in diameter) is greater than the variation in the smaller particles. The concentration of the larger particles is also strongly related to occupant activities, as seen in the last two plots of the figure, in which there are very low levels during the evenings and weekend. The concentration of smaller particles are less variable and less driven by building occupant activities.

Results of the particulate concentration measurements are summarized in Table 4.4. As seen in the table, the average particulate concentrations in all size ranges are much higher in room $\mathrm{B2} .5 \mathrm{~B} 53$ (Space 77 ) than in the other two spaces. The particulate concentrations measured in the Simulator and the Treatment Area lobby are comparable to those of previously measured office buildings [Grot et al 1989]. The concentrations measured in Room B2.5B53 are much higher (roughly an order of magnitude) than typical values for office buildings. ASHRAE Standard 62 bases its recommendation for maximum indoor particulate levels on the National Ambient Air Quality Standards [NAAQS] which are in mass units, not particle concentration. These standards include a long-term average of $75 \mu \mathrm{g} / \mathrm{m}^{3}$ over one year and a short-term average of $260 \mu \mathrm{g} / \mathrm{m}^{3}$ over 24 hours for total suspended particulates. The NAAQS also contains maximums for respirable 
particulates (diameter less than $10 \mathrm{~mm}$ ), a long-term average of $50 \mu \mathrm{g} / \mathrm{m} 3$ and a short-term average of $150 \mu \mathrm{g} / \mathrm{m} 3$ over 24 hours. There is no reliable conversion from particulate concentrations to mass units because of the variability in particle composition, and therefore the data in Table 4.4 can not be directly compared to the ambient standards in the ASHRAE and NAAQS standards. However, if one assumes a particle density of $1.5 \mathrm{mg} / \mathrm{cc}$, the particulate concentrations in Room B2.5B53 are about $90 \mu \mathrm{g} / \mathrm{m} 3$, which is quite high. Particulate measurements were also made with the aerosol mass monitor which does provide readings in mass units. These measurements were made several months after the measurements of particulate concentrations with the light-scattering particle counter. The mass monitor provides a reading of the particulate level in any location at a given time, not the temporal profile obtained with the particle counter. All of the readings taken with the mass monitor were $30 \mu \mathrm{g} / \mathrm{m} 3$ or less, even in Room B2.5B53. The high concentrations measured in this room with the particle counter at an earlier date show that there is the potential for high particulate levels in this space at certain times. These high levels may be due to activities within or outside of the building and airflow patterns that transport the particulate matter to this space.

Levels of volatile organic compounds (VOCs) were measured in the ROB on two occasions, and the results are presented in Table 4.5. The first series of measurements was made on the afternoon of 11 May 1989 and was intended to identify the compounds existing in the facility. These measurements were made in the return and exhaust ducts of Zone \#1, and in the exhaust ducts of Zones \#2 through \#4. These results are listed in the first column for each of the zones in Table 4.5, in which the compounds that were identified in each zone are noted with an $\mathrm{X}$. These measurement results do not provide a quantitative measure of the concentrations of these VOCs.

Another series of samples was collected on 8 June 1989, again in the afternoon, in order to determine the concentrations of some of these compounds. In this second series of measurements, samples were also collected on the roof of the Treatment Area mechanical room to determine the outdoor level of these compounds. The concentrations were determined by comparison with standard samples, and therefore only those compounds for which standards were available could be quantified. Those compounds which were identified but not quantified during the second series of tests are noted with an X. Most of the VOCs that were identified in the ROB are light aromatic hydrocarbons. Low levels of benzene and heptane were identified in all zones, at concentrations comparable with those measured outside. Methylbenzene and dimethylbenzene were also identified in all zones, with lower levels outdoors than indoors. Several other compounds were identified in the various zones, and although their concentrations were not precisely quantified against standards, the levels do appear to be relatively low. 
The concentrations of the compounds that were measured are at very low levels, several orders of magnitude below any OSHA exposure limits. There are no VOC standards for the nonindustrial environment although target concentrations of 1 $\mathrm{mg} / \mathrm{m}^{3}$ [Tucker 1988] and $5 \mathrm{mg} / \mathrm{m}^{3}$ [Molhave 1985] for total VOCs have been suggested. The levels measured in this facility are well below these targets, however there may be much higher levels in the event of a chemical release within the $R O B$ or elsewhere in or near the building. The existence of significant interzone aiflows between the ROB and elsewhere, identified in Task 3 , indicates the possibility of such contaminant transport.

Thermal comfort within the ROB was evaluated through the measurement of air temperature and relative humidity levels. ASHRAE [1989] indicates ranges of temperature and relative humidity for which people are expected to be comfortable. During the winter, comfortable conditions for the occupants correspond to temperatures from about 68 to $73^{\circ} \mathrm{F}$ and from about $25 \%$ to $85 \% \mathrm{RH}$. In the summer they range from about 73 to $78^{\circ} \mathrm{F}$ and from $20 \%$ to $65 \% \mathrm{RH}$. These ranges are based on occupant activity levels classified as at or near sedentary. Many of the occupants of the ROB spend much of their time at higher activity levels, and therefore the comfort limits for these occupants are even lower.

Tables $4.6 \mathrm{a}$ and $4.6 \mathrm{~b}$ show the results of the temperature and relative humidity surveys of the ROB. The first table is based on a temperature survey of almost every room that included a measurement in the morning and another in the afternoon. The afternoon measurements were generally higher than the morning readings due to the build-up of heat from lights, occupants and equipment during the day. Readings with an air temperature below $70^{\circ} \mathrm{F}$ and above $76^{\circ} \mathrm{F}$ are in bold type. Most of the spaces in the ROB have temperatures conducive to maintaining a reasonable level of occupant comfort, but there are some exceptions. The ground level entrance to the Treatment Area and the below grade reception area, located just below the entrance, were both measured to be quite warm. The entrance and reception areas are covered by a large, sloping glass roof, which causes these spaces to become quite hot on sunny days. Spaces 57 and 58 , the simulator and simulator control rooms, were found to be at very low temperatures. These low temperatures are a particular problem because patients, wearing only lightweight robes, are required to remain still for extended periods of time in the simulator. Other spaces with low or high temperatures are noted in the table.

Table $4.6 \mathrm{~b}$ presents the results of three follow-up temperature and relative humidity surveys. During the first survey the relative humidity throughout the ROB was quite low, just barely within the comfort guidelines referred to above. During the second survey, the indoor relative humidity was even lower, just above $10 \%$. The low humidity levels were pointed out to the building maintenance staff and 
some adjustments were made to the Treatment Area HVAC system. In the third survey, conducted after these adjustments, the relative humidity levels in the Treatment Area were at a reasonable level, but the readings in the rest of the ROB were still relatively low. The existence of spaces with temperatures outside of desirable ranges, and the low humidity levels, are indicative of a thermal comfort problem that could account for some of the occupant complaints. The elevated temperatures are most likely caused by an inadequate supply airflow rate to the particular space given the thermal loads of that space. Conversely, the spaces with low temperatures probably have excessive supply airflow rates. These problems can be remedied through balancing adjustments within the ventilation system, although some diffuser modifications may also be necessary. The low relative humidity levels may be due to inadequate capacity for humidification or poor performance of HVAC controls.

\section{Summary of Task 4 Results}

The measured levels of carbon dioxide, carbon monoxide, formaldehyde, radon, particulates, and VOCs in the ROB were generally low relative to ASHRAE Standard 62. The findings of all the contaminant level measurements are summarized in this section.

The carbon dioxide concentrations within the ROB were well within ASHRAE recommendations and were consistent with the measured ventilation rates and building occupancy levels. Some spaces were at higher levels than the rest of the facility, including the nurses station in the Treatment Area and the conference room on Level B2.5B. These elevated levels, while not a matter of concern in and of themselves, do indicate a lower ventilation rate relative to the number of occupants than elsewhere in the facility.

No significant concentrations of carbon monoxide were measured in the facility, with the CO levels well within the ASHRAE recommendations (based on EPA ambient air quality standards). These measurements were made on only a limited number of occasions, and therefore these low readings are not inconsistent with occasional complaints about motor vehicle exhaust fumes in the space.

The measured levels of both formaldehyde and radon were very low throughout the ROB. In both cases the concentrations were at or below the minimum detectable limit of the measurement devices and well below the ASHRAE recommendations for indoor levels.

The measured concentrations of airborne particulates were generally low in the facility, at levels typical for office spaces. The particulate concentrations measured in an office on Level B2.5B with the light-scattering particle counter were significantly higher than levels we have measured in other office spaces. Although 
there is no reliable conversion from particulate concentrations to mass units, the results in this room appear to be on the order of magnitude of the maximum levels in ambient air quality standards. Additional measurements were made in this same space using an aerosol mass monitor and the readings were low, indicating that the high levels obtained with the particle counter do not always exist and may have been associated with a particular event within or outside of the building and aiflow patterns that transported the particulate matter into the space. These results merit further study as to prevalence of these high levels and the composition of the particulate matter.

The evaluation of volatile organic compounds in the ROB identified some light aromatic hydrocarbons, along with other substances. All were at very low levels and some were quite close to the outdoor concentrations, suggesting that there are no indoor sources for these particular substances. All of the measured concentrations were several orders of magnitude below the OSHA limits for the workplace. They were also quite low in comparison to suggested levels for the total VOC burden for nonindustrial buildings. These results, though quite low, are only relevant to the time at which the measurements were made. VOC levels could certainly be higher at other times. For example, if there were an inadvertent chemical release in or near the building, the interzone aiflows prevalent in this building could lead to significant transport of contaminants and elevated concentrations.

The evaluation of thermal comfort in the facility revealed several spaces with conditions that were not conducive to occupant comfort. Cases of both very warm and very cold rooms were found. Generally low levels of relative humidity prevailed throughout the space. There appears to be deficiencies in the HVAC controls for the facility that lead to these uncomfortable conditions. 
Table 4.1 Daily Peak $\mathrm{CO}_{2}$ Concentrations (ppm)

\begin{tabular}{|l|c|c|c|}
\hline LOCATION & MEAN & $\begin{array}{c}\text { STANDARD } \\
\text { DEVIATION }\end{array}$ & MAXIMUM \\
\hline ZONE 1 RETURN & 464 & 26 & 511 \\
\hline ZONE 1 EXHAUST & 442 & 31 & 505 \\
\hline ZONE 2/3 EXHAUST & 447 & 28 & 497 \\
\hline ZONE 4 EXHAUST & 487 & 32 & 565 \\
\hline
\end{tabular}

\begin{tabular}{|c|c|c|c|c|}
\hline \multirow{2}{*}{\multicolumn{5}{|c|}{\begin{tabular}{|l} 
SPACE \# \\
ZONE 1
\end{tabular}}} \\
\hline & & & & \\
\hline 10 & 85 & 518 & - & 555 \\
\hline 24 & Waiting & 471 & - & 488 \\
\hline 34 & 200 & 627 & - & 659 \\
\hline 57 & $413 B$ & 493 & . & 511 \\
\hline 70 & 101 & 513 & $=$ & 523 \\
\hline \multicolumn{5}{|l|}{ ZONE 2} \\
\hline 8 & B3B 47 & 588 & - & 895 \\
\hline 10 & B3B 48 & 482 & - & 524 \\
\hline 21 & B3B 34 & 532 & - & 585 \\
\hline 29 & B3B 35 & 469 & $=$ & 533 \\
\hline \multicolumn{5}{|l|}{ ZONE 3} \\
\hline 57 & $82.5 B 38$ & 591 & 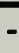 & 843 \\
\hline 66 & B2.5B 35 & 475 & . & 544 \\
\hline 77 & $82.5 B 53$ & 542 & $=$ & 616 \\
\hline \multicolumn{5}{|l|}{ ZONE 4} \\
\hline$\overline{7}$ & $1 B 47 C$ & 439 & 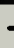 & 499 \\
\hline 18 & 1B 37B & 410 & . & 447 \\
\hline 22 & 1B 52 & 396 & 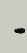 & 437 \\
\hline 23 & 1850 & 465 & - & 507 \\
\hline
\end{tabular}

ASHRAE Standard 62-1981 contains a maximum $\mathrm{CO}_{2}$ concentration of 2500 $\mathrm{ppm}$. The 1989 revision of this standard reduces this maximum to $1000 \mathrm{ppm}$. 
Table 4.2 Measured Formaldehyde Concentrations

\begin{tabular}{|c|c|c|c|}
\hline SPACE \# & ROOM \# & $\begin{array}{l}\text { FORMALDEHYDE CONCENTRATION } \\
(\mathrm{ppm})\end{array}$ & SAMPLE PERIOD \\
\hline \multicolumn{4}{|l|}{ ZONE 1} \\
\hline 10 & $\overline{85}$ & 0.01 & $2 / 13 / 89-2 / 21 / 89$ \\
\hline 24 & Waiting Area & 0.01 & 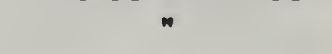 \\
\hline 34 & 200 & 0.02 & " \\
\hline 58 & $413 B$ & 0.02 & 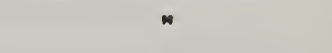 \\
\hline 70 & 101 & 0.02 & $"$ \\
\hline \multicolumn{4}{|l|}{ ZONE 2} \\
\hline 8 & B3B 47 & 0.02 & $2 / 13 / 89-2 / 21 / 89$ \\
\hline 10 & B3B 48 & 0.02 & 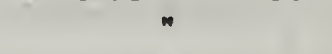 \\
\hline 21 & B3B 34 & 0.01 & 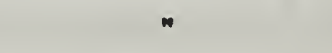 \\
\hline 29 & B3B 35 & 0.02 & " \\
\hline \multicolumn{4}{|l|}{ ZONE 3} \\
\hline 57 & B2.5B 38 & 0.01 & $2 / 13 / 89-2 / 21 / 89$ \\
\hline 66 & B2.5B 35 & 0.01 & " \\
\hline 77 & B2.5B 53 & 0.01 & $n$ \\
\hline \multicolumn{4}{|l|}{ ZONE 4} \\
\hline 7 & $1 B 47 C$ & 0.01 & $2 / 13 / 89-2 / 21 / 89$ \\
\hline 18 & 1B 37B & 0.01 & n \\
\hline 22 & 1B 52 & 0.01 & " \\
\hline 23 & $1 B 50$ & 0.01 & n \\
\hline
\end{tabular}

ASHRAE Standard 62-1981 contains a maximum formaldehyde concentration of $0.1 \mathrm{ppm}$. 
Table 4.3 Measured Radon Levels

\begin{tabular}{|c|c|c|c|}
\hline SPACE \# & ROOM \# & $\begin{array}{l}\text { RADON CONCENTRATION } \\
(p C i / L)\end{array}$ & SAMPLE PERIOD \\
\hline \multicolumn{4}{|l|}{ ZONE 1} \\
\hline $\begin{array}{l}10 \\
24 \\
34 \\
58 \\
70\end{array}$ & $\begin{array}{c}85 \\
\text { Waiting Area } \\
200 \\
413 \mathrm{~B} \\
101\end{array}$ & $\begin{array}{l}\text { less than } 0.4 \\
\text { less than } 0.4 \\
\text { less than } 0.4 \\
\text { less than } 0.4 \\
\text { less than } 0.4\end{array}$ & $\begin{array}{c}2 / 13 / 89 \\
\text { - } 2 / 16 / 89 \\
\text { " } \\
\text { " }\end{array}$ \\
\hline \multicolumn{4}{|l|}{ ZONE 2} \\
\hline $\begin{array}{c}8 \\
10 \\
21 \\
29 \\
\end{array}$ & $\begin{array}{l}\text { B3B 47 } \\
\text { B3B 48 } \\
\text { B3B 34 } \\
\text { B3B 35 } \\
\end{array}$ & $\begin{array}{l}\text { less than } 0.4 \\
\text { less than } 0.4 \\
\text { less than } 0.4 \\
\text { less than } 0.4 \\
\end{array}$ & $\begin{array}{c}2 / 13 / 89-2 / 16 / 89 \\
" " \\
" \\
\end{array}$ \\
\hline \multicolumn{4}{|l|}{ ZONE 3} \\
\hline $\begin{array}{l}57 \\
66 \\
77\end{array}$ & $\begin{array}{l}\text { B2.5B 38 } \\
\text { B2.5B 35 } \\
\text { B2.5B } 53\end{array}$ & $\begin{array}{l}\text { less than } 0.4 \\
\text { less than } 0.4 \\
\text { less than } 0.4\end{array}$ & $\begin{array}{c}2 / 13 / 89-2 / 16 / 89 \\
\text { " }\end{array}$ \\
\hline \multicolumn{4}{|l|}{ ZONE 4} \\
\hline $\begin{array}{l}7 \\
22 \\
23\end{array}$ & $\begin{array}{l}1 B 47 C \\
1 B 52 \\
1 B 50\end{array}$ & $\begin{array}{l}\text { less than } 0.4 \\
\text { less than } 0.4 \\
\text { less than } 0.4\end{array}$ & $\begin{array}{c}2 / 13 / 89-2 / 16 / 89 \\
\text { " }\end{array}$ \\
\hline
\end{tabular}

ASHRAE Standard 62-1981 contains a maximum radon concentation of about $2.5 \mathrm{pCi/L}$. 
Table 4.4 Results of Particulate Measurements

\begin{tabular}{|c|c|c|c|c|c|c|c|}
\hline \multirow{3}{*}{ Location } & \multirow{3}{*}{ Sample Period } & \multicolumn{6}{|c|}{$\begin{array}{c}\text { Average Concentration } \\
\text { (Number of Particles } / \mathrm{m}^{3} \times 1000 \text { ) }\end{array}$} \\
\hline & & \multicolumn{6}{|c|}{ Particle Diameter (microns) } \\
\hline & & $>10$ & $5-10$ & 1.5 & $.7 \cdot 1$ & $.5-.7$ & $.3-.5$ \\
\hline B2.5B 53 & $8 / 19 / 89-8 / 23 / 89$ & 6.08 & 6.14 & 2030 & 15500 & 103000 & 356000 \\
\hline Simulator & $8 / 24 / 89-8 / 30 / 89$ & 0.37 & 0.29 & 21.0 & 43.0 & 825 & 7760 \\
\hline Treatment Area Lobby & $9 / 8 / 89-9 / 16 / 89$ & 0.67 & 0.40 & 38.0 & 201 & 2490 & 11200 \\
\hline Treatment Area Lobby & $9 / 16 / 89-9 / 29 / 89$ & 0.71 & 0.39 & 41.0 & 275 & 2970 & 12300 \\
\hline
\end{tabular}


Table 4.5 Results of VOC Measurements

\begin{tabular}{|l|cc|cc|cc|c|}
\hline \multicolumn{1}{|c|}{ COMPONENT NAME } & \multicolumn{2}{|c|}{ Zone 1 } & \multicolumn{2}{c|}{ Zone 2\&3 } & \multicolumn{2}{c|}{ Zone 4} & \multicolumn{2}{c|}{ Roof } \\
& $5 / 11$ & $6 / 8$ & $5 / 11$ & $6 / 8$ \\
& & $\mu \mathrm{g} / \mathrm{m}^{3}$
\end{tabular}


Table 4.6a Results of Temperature Survey

\begin{tabular}{|c|c|c|c|c|}
\hline \multicolumn{2}{|c|}{ LOCATION } & \multicolumn{2}{|l|}{$\begin{array}{l}4 / 4 / 89 \\
9: 45-11: 05\end{array}$} & \multirow{2}{*}{$\begin{array}{c}\text { 14:50-15:55 } \\
\text { TEMP. } \\
\text { (DEG. F) }\end{array}$} \\
\hline Space & Room & $\begin{array}{l}\text { TEMP. } \\
\text { (DEG. F) }\end{array}$ & $\begin{array}{l}\text { RELATIVE } \\
\text { HUMIDITY }\end{array}$ & \\
\hline \multicolumn{2}{|l|}{ OUTSIDE } & 68.0 & $61 \%$ & 75.9 \\
\hline \multicolumn{5}{|c|}{ TREATMENT AREA } \\
\hline $\begin{array}{l}16 \\
17 \\
18 \\
24 \\
23 \\
34 \\
42 \\
44 \\
45 \\
48 \\
49 \\
39 \\
40 \\
70 \\
50 \\
51 \\
52 \\
71 \\
53 \\
61 \\
60 \\
57 \\
58 \\
28 \\
31\end{array}$ & $\begin{array}{c}\text { Reception } \\
79 \\
81 \\
85 \\
\text { Entrance } \\
201 \\
301 \\
\text { Control 1/2 } \\
\text { Waiting } \\
204 A \\
200 \\
204 B \\
101 A \\
101 C \\
406 B \\
406 A \\
406 E \\
406 D \\
101 \\
100 \\
102 C \\
102 B \\
102 A \\
104 \\
106 B \\
106 \\
413 B \\
413 \\
403 \\
\text { Control } 3 / 4\end{array}$ & $\begin{array}{l}76.3 \\
72.3 \\
76.3 \\
75.9 \\
75.2 \\
73.8 \\
73.9 \\
74.3 \\
73.0 \\
73.0 \\
73.9 \\
73.9 \\
74.7 \\
74.7 \\
70.7 \\
73.9 \\
69.4 \\
69.4 \\
73.0 \\
74.3 \\
73.6 \\
72.3 \\
74.3 \\
72.7 \\
70.7 \\
71.4 \\
67.5 \\
68.5 \\
72.3 \\
73.0 \\
\end{array}$ & $\begin{array}{l}41 \% \\
43 \%\end{array}$ & $\begin{array}{l}74.3 \\
72.7 \\
74.3 \\
71.1 \\
73.0 \\
74.7 \\
72.3 \\
75.2 \\
72.7 \\
72.0 \\
72.5 \\
67.8 \\
68.5 \\
72.3 \\
73.6 \\
\end{array}$ \\
\hline \multicolumn{5}{|c|}{ LEVEL B3B } \\
\hline $\begin{array}{r}42 \\
41 \\
39 \\
8 \\
9 \\
33 \\
32 \\
27 \\
29 \\
30 \\
28 \\
26 \\
22 \\
21 \\
20 \\
17 \\
18 \\
11 \\
10 \\
46 \\
\end{array}$ & $\begin{array}{l}55 \\
51 \\
49 \\
47 \\
47 \\
39 \\
39 \\
35 \\
35 \\
35 \\
33 \\
31 \\
32 \\
34 \\
36 \\
36 \\
36 \\
48 \\
48 \\
56 \\
\end{array}$ & $\begin{array}{l}72.0 \\
69.1 \\
75.6 \\
71.4 \\
72.7 \\
71.1 \\
72.7 \\
74.3 \\
74.7 \\
73.9 \\
73.0 \\
71.4 \\
70.3 \\
72.5 \\
76.3 \\
73.0 \\
72.3 \\
71.4 \\
72.7 \\
76.3 \\
\end{array}$ & & $\begin{array}{l}73.9 \\
71.1 \\
74.3 \\
73.0 \\
71.2 \\
73.0 \\
77.2 \\
75.9 \\
76.3 \\
74.7 \\
72.3 \\
73.0 \\
75.9 \\
72.7 \\
72.3 \\
72.3 \\
73.0 \\
75.6 \\
\end{array}$ \\
\hline
\end{tabular}

\begin{tabular}{|c|c|c|c|}
\hline \multirow{2}{*}{\multicolumn{2}{|c|}{ LOCATION }} & \multirow{2}{*}{\begin{tabular}{|c|}
$4 / 4 / 89$ \\
$9: 45-11: 05$ \\
TEMP. \\
(DEG. F)
\end{tabular}} & \multirow{2}{*}{$\frac{14: 50-15: 55}{\text { TEMP. }}$} \\
\hline Space & & & \\
\hline \multicolumn{4}{|c|}{ LEVEL B2.5B } \\
\hline 77 & 53 & 73.6 & \\
\hline 76 & 53 & 73.9 & 73.9 \\
\hline 75 & 53 & 73.9 & 73.9 \\
\hline 74 & 49 & 71.1 & 73.6 \\
\hline 73 & 49 & 72.0 & 73.6 \\
\hline 72 & 49 & 72.3 & , 74.3 \\
\hline 71 & 45 & 73.6 & \\
\hline 67 & 41 & 73.0 & 73.6 \\
\hline 68 & 39 & 73.6 & 75.9 \\
\hline 66 & 35 & 73.6 & 73.9 \\
\hline 65 & 35 & 73.0 & 72.7 \\
\hline 64 & 33 & & 72.7 \\
\hline 63 & 33 & 72.7 & 72.7 \\
\hline 57 & 57 & 73.0 & 73.0 \\
\hline 49 & 48 & 74.7 & 7.2 \\
\hline 50 & 48 & 73.9 & 75.2 \\
\hline \multicolumn{4}{|c|}{ LEVEL $1 B$} \\
\hline 1 & $53 C$ & 74.7 & 74.7 \\
\hline 2 & 538 & 73.6 & 74.3 \\
\hline 4 & $53 A$ & 74.7 & 75.6 \\
\hline 3 & $51 B$ & 73.9 & 73.9 \\
\hline 5 & $51 C$ & 75.2 & 75.9 \\
\hline 6 & 51A & 74.7 & 75.2 \\
\hline 7 & $47 C$ & 75.2 & 75.2 \\
\hline 9 & 470 & 72.3 & \\
\hline 10 & 47A & & 74.8 \\
\hline 13 & 43 & 74.7 & 75.6 \\
\hline 17 & $37 A$ & 75.2 & 75.2 \\
\hline 18 & 378 & 73.9 & 74.7 \\
\hline 19 & 35 & 70.5 & \\
\hline 35 & 34 & 75.2 & 7.0 \\
\hline 32 & $40 A$ & 73.0 & 76.3 \\
\hline 31 & $44 A$ & 78.4 & 79.5 \\
\hline 29 & $42 A$ & 77.5 & 78.4 \\
\hline 27 & $50 A$ & 74.7 & 75.2 \\
\hline 26 & $50 B$ & 73.9 & 75.9 \\
\hline 22 & 52 & 74.3 & 74.7 \\
\hline 21 & 54 & 76.3 & 7.2 \\
\hline 20 & 58 & 75.9 & \\
\hline
\end{tabular}


Table 4.6b Results of Temperature and Humidity Survey

\begin{tabular}{|c|c|c|c|c|c|c|c|}
\hline \multicolumn{2}{|c|}{ LOCATION } & \multicolumn{2}{|l|}{$\begin{array}{l}4 / 7 / 89 \\
12: 50-13: 30 \\
\end{array}$} & \multicolumn{2}{|l|}{$\begin{array}{l}/ 11 / 89 \\
13: 15 \\
\end{array}$} & \multicolumn{2}{|l|}{\begin{tabular}{|l|}
$4 / 28 / 89$ \\
$14: 10$ \\
\end{tabular}} \\
\hline Space & Room & $\begin{array}{l}\text { TEMP. } \\
\text { (DEG. F) }\end{array}$ & $\begin{array}{l}\text { RELATIVE } \\
\text { HUMIDITY }\end{array}$ & $\begin{array}{l}\text { TEMP. } \\
\text { (DEG.F) }\end{array}$ & $\begin{array}{l}\text { RELATIVE } \\
\text { HUMIDITY }\end{array}$ & $\begin{array}{l}\text { TEMP. } \\
\text { (DEG. F) }\end{array}$ & $\begin{array}{l}\text { RELATIVE } \\
\text { HUMIDITY }\end{array}$ \\
\hline \multicolumn{2}{|l|}{ OUTSIDE } & 48.7 & $65 \%$ & 53.6 & $22 \%$ & 74.3 & $25 \%$ \\
\hline \multicolumn{8}{|c|}{ TREATMENT AREA } \\
\hline 1 & Reception & 70.7 & $28 \%$ & 78.8 & $12 \%$ & 76.8 & $32 \%$ \\
\hline 10 & $\begin{array}{c}85 \\
\text { Entranco }\end{array}$ & $\begin{array}{l}72.7 \\
72.7\end{array}$ & $\begin{array}{l}26 \% \\
26 \%\end{array}$ & 75.2 & $12 \%$ & $\begin{array}{l}73.9 \\
80.8\end{array}$ & $\begin{array}{l}35 \% \\
26 \%\end{array}$ \\
\hline 24 & Waiting & 71.4 & $27 \%$ & \multirow[t]{2}{*}{73.9} & \multirow[t]{2}{*}{$13 \%$} & 73.6 & $34 \%$ \\
\hline 34 & 200 & 72.3 & $27 \%$ & & & 74.3 & $36 \%$ \\
\hline 70 & 101 & 72.0 & $27 \%$ & \multirow[t]{3}{*}{73.4} & \multirow[t]{3}{*}{$13 \%$} & 73.6 & $35 \%$ \\
\hline 52 & $102 B$ & 73.0 & $26 \%$ & & & 72.3 & $37 \%$ \\
\hline 57 & $413 B$ & & & & & 73.9 & $35 \%$ \\
\hline 58 & 413 & 69.1 & $30 \%$ & 73.9 & $12 \%$ & 73.6 & \\
\hline \multicolumn{8}{|c|}{ LEVEL $B 3 B$} \\
\hline 29 & 35 & 73.0 & $26 \%$ & 72.7 & $11 \%$ & 75.2 & $27 \%$ \\
\hline 21 & 34 & 74.7 & $28 \%$ & 74.7 & $10 \%$ & 74.7 & $24 \%$ \\
\hline 10 & 48 & 73.0 & 22.8 & 73.9 & $12 \%$ & 75.6 & $23 \%$ \\
\hline \multicolumn{8}{|c|}{ LEVEL $82.5 B$} \\
\hline 76 & 53 & 73.6 & $26 \%$ & 73.0 & $12 \%$ & $\overline{74.7}$ & $24 \%$ \\
\hline 66 & 35 & 73.9 & $25 \%$ & 73.6 & $11 \%$ & & \\
\hline 65 & 35 & 73.9 & $25 \%$ & 73.6 & $11 \%$ & 73.9 & $25 \%$ \\
\hline 57 & 57 & 73.0 & $26 \%$ & 72.3 & $10 \%$ & 73.9 & $24 \%$ \\
\hline \multicolumn{8}{|c|}{ LEVEL 18} \\
\hline 7 & $47 \mathrm{C}$ & 74.3 & $25 \%$ & & & & \\
\hline 9 & 47D & 73.4 & $22 \%$ & & & & \\
\hline 18 & $37 B$ & 73.0 & $27 \%$ & 74.3 & $12 \%$ & 76.8 & $24 \%$ \\
\hline 23 & $46 / 50$ & 73.0 & $26 \%$ & 73.9 & $11 \%$ & 76.8 & $24 \%$ \\
\hline
\end{tabular}




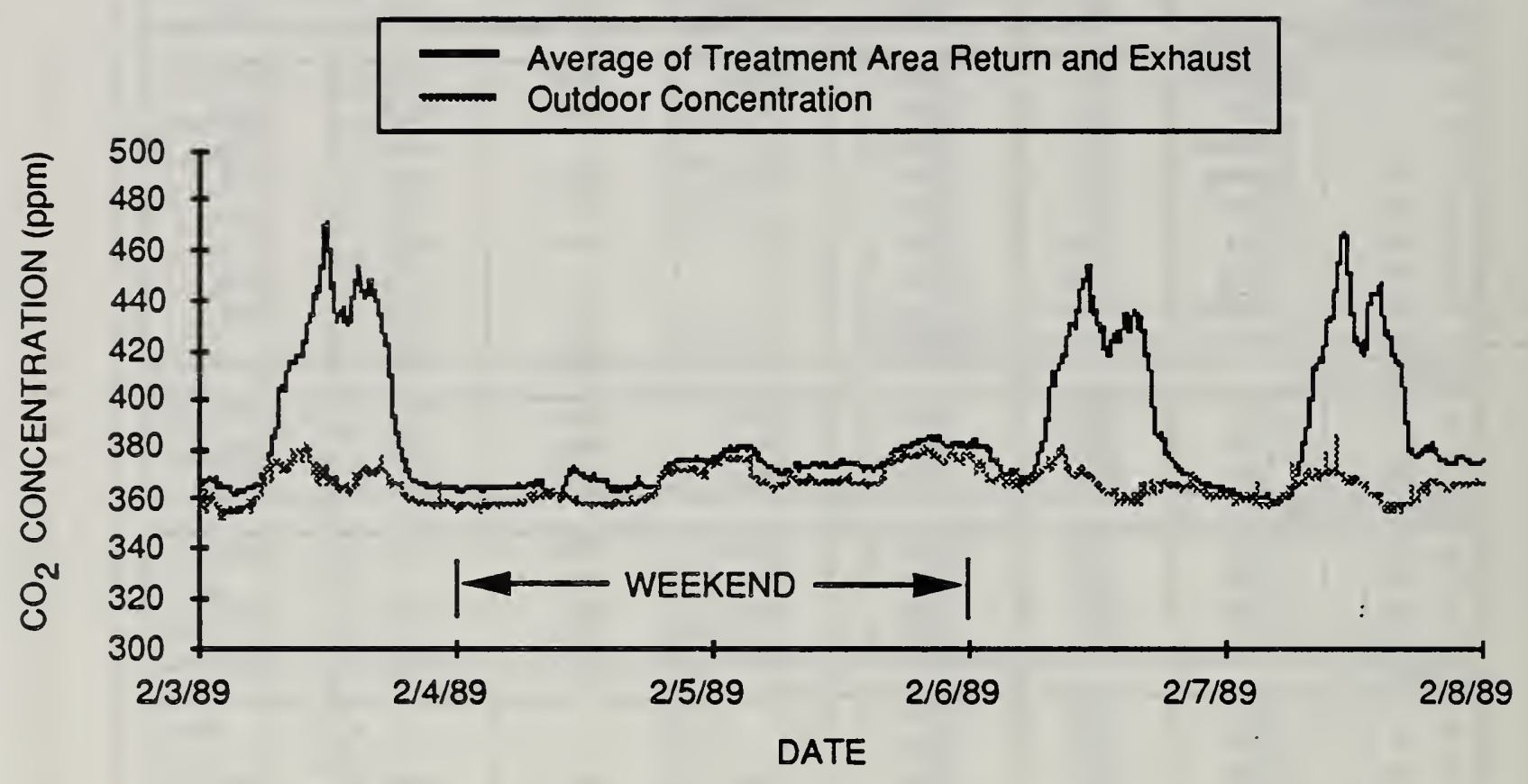

Figure 4.1 Carbon Dioxide Concentrations in Treatment Area 



\section{TASK 5: RECOMMENDATIONS}

The air quality investigation of the Radiation Oncology Branch at the National Institutes of Health has not revealed any critical air quality problems in terms of high pollutant levels or low ventilation rates. Both the measured pollutant levels and the ventilation rates were generally in agreement with the ASHRAE air quality standard and the HHS construction guidelines. However, several deficiencies were identified which could be responsible for some of the air quality complaints that have been expressed by the occupants of the ROB. This section summarizes these deficiencies and contains recommendations for their remediation.

Tasks 1 and 2, the ventilation system design review and inspection, revealed the following deficiencies that should be corrected.

- The design documentation for the ROB mechanical ventilation systems, and indeed the entire $B$ corridor, needs to be updated. It was difficult to evaluate several aspects of the ventilation system design of the facility because current design information was not available. In particular, there was no up-to-date information on the $\mathrm{B}$ corridor ventilation system for use in understanding the relation of the ROB facility to the airflow patterns of the entire corridor. Mechanical drawings of the air distribution systems, fan schedules, and design airflow rates should be developed for the ROB, as well as for the rest of the B corridor.

- The analysis of the ventilation system design did reveal several instances in which the design deviated from current ASHRAE and HHS design guidelines. For example, there is no provision for outdoor air supply to the Treatment Area reception area. In addition, one copy room has no mechanical ventilation and another is connected to the return air system when it should be exhausted to the outdoors. Several of the laboratory spaces have an excess of supply airflow over exhaust air when they should be exhausted. The ventilation system design should be changed to correct these deficiencies, and the equipment and components should be modified accordingly.

- The inspection of the ROB ventilation system revealed several items that should be repaired. Damaged or missing ceiling tiles need to be replaced. The fan coil units in Linacs \#1 through \#3 are pulling air from the ceiling plenum when they should be drawing air from the occupied space. There are holes in the general exhaust duct serving Level $1 \mathrm{~B}$, reducing the exhaust airflows from the occupied space, and these should be repaired.

- The controls of the smoke/fire dampers in the Treatment Area need to be evaluated to prevent unintentional closing of these dampers and to facilitate the prompt identification of such closings. When the investigation of the ROB began several of these dampers were closed, leading to undesirable air exchange conditions in many locations in the Treatment Area. They were reopened when we 
notified the maintenance staff, but it is important to prevent future damper closings and to identify them when they occur. A procedure for checking damper positions needs to be developed and implemented.

Tasks 3 and 4 involved physical measurements of the airflow rates and contaminant levels within the ROB. These measurements revealed the following deficiencies in the performance of the ventilation systems which should be corrected.

- The air handling systems throughout the entire ROB are in need of balancing. Fan airflow rates, as well as airflow rates to and from individual rooms, are in many instances quite different from their design values. Some of these circumstances are more critical than others, but all of them should be corrected. The specific areas requiring attention are listed in the section on Task 3.

- A significant amount of duct leakage was identified in the air handling systems, and this needs to be repaired. This duct leakage is leading to some of the differences between measured and design airflow rates to individual rooms. The leakage in the Treatment Area return air duct is of particular concern because the air flowing into this duct is recirculated into the supply air for this space.

- Conditions of poor thermal comfort were identified in several rooms within the $R O B$, including spaces that were too hot and others that were too cold. In addition, the relative humidity within the space was generally quite low. Again, notification of the maintenance staff of the low humidity levels in the Treatment Area led to an improvement in the conditions. There is still a need to evaluate the HVAC controls for the ROB, including an analysis of the thermal loads within the spaces. Thermal comfort parameters outside of the recommended limits are almost certainly responsible for some of the complaints and need to be improved.

In addition to the above deficiencies, Tasks 3 and 4 efforts also revealed the importance of interzone airflows and contaminant transport in this building. Interzone airflow and contaminant transport are very important air quality issues for the ROB given the range of activities and associated substances occurring in and near the building. Interzone airflows were shown to exist, creating the potential for contaminant transport within the building and from sources outside of the building. The close proximity of different space types, such as patient care areas and laboratories, is an inherently difficult situation even under ideal circumstances. It is difficult if not impossible to isolate these different activities in terms of airflow, and the only way to eliminate contaminant transport between these spaces is to prohibit their existence in the same building. Similarly, pollutant sources located outside of the building also make interzone airflow an indoor air quality problem, and the only way to eliminate the contaminant transport is to remove the contaminants. Factors 
contributing to the interzor recommendations for their

- The interzone airflow s when the supply fan servir supply air flow rate, there rates. This "unbalanced" larger amount of supply ai spaces to be at a positive into the laboratories from $t$ Level B3B is used to trans exposed to the substances Treatment Area. The dire hallway should be correcte airflow rate from Levels $B=$ in the exhaust airflow rate patterns in the building. $C$ elevator shafts, and then ts exhaust airflow from Level air into these levels from th areas in the building could

- The numerous exhaust outlets, presents an undes down, resulting in the entr: intakes. Such entrainmen problem depending on the exhaust system situation $c$ of-the-art recommendatior

- There are many contar the building including trast the loading docks and mo Contaminants from these: the building causing odor contaminant exposures to eliminate the airflow trans: removed. Trash should nc not be located close to the or near the building loadin facility, in conjunction with building, would eliminate $t$ airflow and contan mediation, are dis

ation in this buildin Levels B2.5B and $s$ no correspondin dification resulted lative to exhaust, ssure relative to $t$ hallways, not the $t$ many patients tc ligrating from thes in of the airflows $b$ and this can be $d$ and $B 2.5 B$. It is $n$ these zones wou ently, air is flowinc ome of the upper $33 \mathrm{~B}$ and $\mathrm{B} 2.5 \mathrm{~B}$ Co stair and elevator en be transported

stems for the B cc ble situation. Mar ment of contamine as been demonstr bstances being $e$ he $B$ corridor roof egarding outlet $d \epsilon$

ant sources locatt umpsters in the fr. vehicles which idl urces are able to $n$ blems and the po ? building occupar ting these contam se stored within th jilding, and motor ocks. The use of zctric carts to trans source problem. lant transport problems, and sssed below.

is complicated by the fact that 3B was modified, increasing the change to the exhaust airflow these zones having a significan y zusing many of the laboratory hallway. Air should be flowing her way around. The hallway or 1e Treatment Area and they. will ? laboratories on their way to the ween these laboratories and the le by increasing the exhaust clear, however, how an increase affect the interzone airflow rom these levels, into the stair a ors of the building. Increasing th I reverse these patterns, pulling afts. Contaminants from other the ROB.

idor, and the configuration of the of these outlets are pointing d exhaust air by the $B$ corridor a ed and could present a serious austed at a particular time. The zeds to be evaluated using state gn and outlet velocities.

within the building and outside tht elevator lobbies and outside at the loading docks. rate into the occupied space of titial for more significant - Since it is not possible to ants, these sources should be suilding, trash dumpsters should thicles should not be operating c 1 off-site receiving and trash ort material to and from the 
BS.114A (REV. 2.8C)

U.S. DERT. OF COMM

BIBLIOGRAPHIC DATA

SHEET (See instruction s)

1. PUBLICATION OR

REPORT NO.

$89-4145$

2. Performing Organ. Report Nof 3. Publication Date

AUGUST 1989

4. TITLE AND SUBTITLE

Air Quality Investigation in the NIH Radiation Oncology Branch

5. $A \cup T H O R(S)$

Andrew Persily, W. Stuart Dols, Steven J. Nabinger and David A. VanBronkhorst

5. PERFORMING ORGANIZATION (If joint or other than NBS, see instructions)

7. ContractGrant No.

\section{NATIONAL BUREAU OF STANDARDS \\ U.S. DEPARTMENT OF COMMERCE GATTHERSBURG, MD 20899}

3. SPONSORING ORGANIZATION NAME AND COMPLETE ADDRESS (Street, City。 State, ZIP)

8. Type of Report \& Period Covered

Division of Engineering Services

National Institutes of Health

Bethesda, Maryland

0. SUPPLEMENTARY NOTES

Document describes a computer program; SF-185, FIPS Software Summary, is attached.

11. ABSTRACT (A 200-word or less factual summary of most significant information. If document includes a significant

bibliography or literature survey, mention it here)

The Radiation Oncology Branch (ROB) is located in the Clinical Center of the National Institutes of Health (NIH). The occupants of the ROB facility have expressed dissatisfaction with the air quality within the facility for several years. While a variety of occupant complaints have been noted, the specific causes have never been determined due to the complex nature of the facility and current limitations in the ability to diagnose indoor air quality problems. In order to identify the sources of the air quality problems in the ROB facility and to obtain recommendations for their solution, the Division of Engineering Services (DES) of NIH contracted with the Center for Building Technology at the National Institute of Standards and Technology (NIST, formerly the National Bureau of Standards) to conduct an indoor air quality investigation of the ROB facility.

The NIST study of the ROB facility involved five separate tasks. The first task was to review current design documents of the ROB HVAC systems and compare the design to the ASHRAE air quality standard and HHS construction guidelines. The second task was to conduct an inspection of the existing HVAC systems. The third task was to conduct tracer gas studies of the facility in order to quantify its air exchange and air movement characteristics. The fourth task was to monitor contaminant levels in the facility in order to determine if they exceed current standards. The fifth task was to recommend modifications to the facility in order to improve.its indoor air quality. This report presents the results of all five tasks of the indoor air quality investigation of the Radiation Oncology Branch.

The first two tasks revealed several deficiencies in the design and current condition of the ROB ventilation system, such as significant differences between the design aifflow rates and those recommended in current standards and guidelines. The airflow measurements in Task 3 showed many instances in which measured airflow rates were different from their design values. This task also revealed the existence of airflows within the building leading to.the potential for pollutant transport within the building. The contaminant measurements conducted in Task 4 generally well below the maximum values in the ASHRAE air quality standard. Thermal comfort measurements revealed instances when the temperature and relative humidity were outside of ASHRAE comfor limits. Recommendations are made to remedy the deficiencies noted and to control the conditions contributing to the building's air quality problems.

12. KEY WORDS (Six to twelve entries; alphabetical order: capitalize only proper names; and separaze key words by semicolons)

air flow, air movement, building diagnostics; building performance; indoor air quality; indoor pollution; laboratory ventilation; tracer gas; ventilation.

13. AVAILABILITY

X. Unlimited

For Official Distribution. Do Not Release to NTIS Order From Superintendent of Documents, U.S. Government Printing Office, Washington, D.C.
20402 .

14. NO. OF PRINTED PAGES

X Order From National Technical Information Service (NTIS), Springfield, VA. 2216I 

